\title{
CARACTERIZAÇÃO DA LOCALIZAÇÃO SUBCELULAR DA PROTEÍNA THI1 DE Arabidopsis thaliana
}

\author{
SABRINA MOUTINHO CHABREGAS
}

Tese apresentada à Escola Superior de Agricultura "Luiz de Queiroz", Universidade de São Paulo, para obtenção do título de Doutor em Agronomia, Área de Concentração: Genética e Melhoramento de Plantas.

PIRACICABA

Estado de São Paulo - Brasil

Dezembro - 2001 


\title{
CARACTERIZAÇÃO DA LOCALIZAÇÃO SUBCELULAR DA PROTEÍNA THI1 DE Arabidopsis thaliana
}

\author{
SABRINA MOUTINHO CHABREGAS \\ Engenheiro Agrônomo
}

Orientador: Prof. Dr. MARCIO DE CASTRO SILVA FILHO

\begin{abstract}
Tese apresentada à Escola Superior de Agricultura "Luiz de Queiroz", Universidade de São Paulo, para obtenção do título de Doutor em Agronomia, Área de Concentração: Genética e Melhoramento de Plantas.
\end{abstract}

PIRACICABA

Estado de São Paulo - Brasil

Dezembro - 2001 
Dados Internacionais de Catalogação na Publicação (CIP) DIVISÃO DE BIBLIOTECA E DOCUMENTAÇÃO - ESALQ/USP

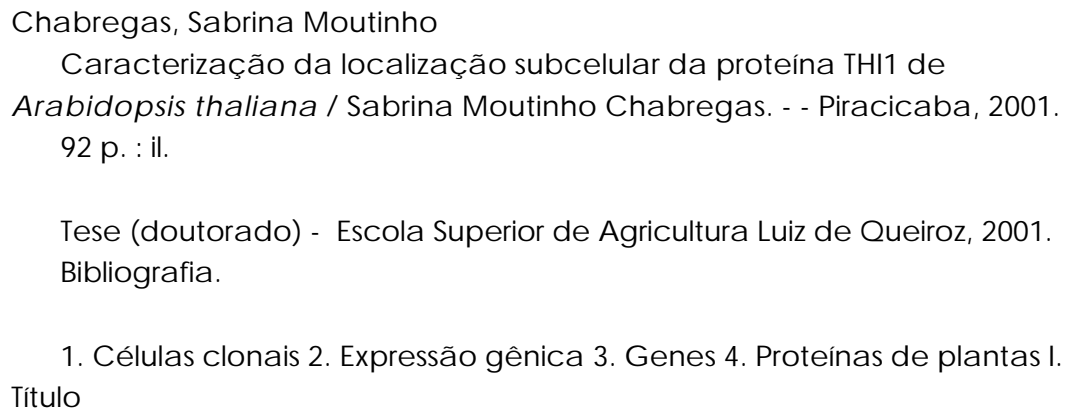

1. Células c lona is 2. Expressão gênic a 3. Genes 4. Proteínas de plantas I. Título

CDD 575.1

\section{"Permitida a cópia total ou parcial deste documento, desde que citada a fonte - $\mathrm{O}$ autor"}


Aos meus pais lara e José Chabregas, A quem devo tudo o que sou,

\section{OFEREÇO}

A Reinaldo e Nathália,

Que me fazem ter vontade de me tornar melhor,

\section{DEDICO}




\section{AGRADECIMENTOS}

Agradeço a todas as pessoas que, de forma direta ou indireta, contribuíram para a realização deste trabalho, especialmente:

Ao Prof. Dr. Marcio de Castro Silva Filho pela orientação, amizade e incentivo em todos os momentos.

Ao Prof. Dr. Carlos F. M. Menck, ICB2 - USP, e Prof ${ }^{a}$. Dra. MarieAnne van Sluys, IB, USP, pela colaboração, discussões de resultados, sugestões e amizade.

Ao Prof. Alberto Ribeiro, IB - USP e a Waldir Caldeira, pela realização dos experimentos de imunolocalização.

Ao Prof. Dr. Ian Small, INRA, França, e Prof. Dr. Marc Boutry, Université Catholique de Louvain, Bélgica, pelos anticorpos e plasmídeos fornecidos, além das sugestões e colaboração.

Ao Prof. Carlos Alberto Labate, Departamento de Genética, ESALQ - USP, pelo anticorpo anti-Rubisco.

A Douglas D. Luche, Leonardo P. Farias e Paulo Henrique Conaggin Godoi pela significativa colaboração no trabalho e amizade.

Aos colegas do Laboratório de Biologia Molecular de Plantas, ESALQ - USP, pela amizade, paciência e incentivo em todos os momentos, tornando o ambiente de trabalho muito estimulante e agradável. 
Aos colegas do Laboratório de Biologia Celular, ESALQ - USP, pela amizade e colaboração em todos os momentos, em especial, à Dra. Vera Maria Quecini e Mariza Monteiro pelo auxílio nos experimentos de eletroporação de protoplastos e à Prof ${ }^{a}$. Dra. Maria Lúcia Carneiro Vieira por colocar seu laboratório à disposição.

Aos colegas do Laboratório de Genética de Leveduras, ESALQ USP, em especial a Dra. Keila Maria Roncato Duarte e Dr. Luiz Humberto Gomes pela boa vontade em auxiliar em vários pontos do trabalho e ao Prof. Dr. Flávio César Almeida Tavares por colocar seu laboratório à disposição.

Aos colegas do Laboratório de Citogenética, ESALQ - USP, em especial a Dra. Janay A. Santos, Dra. Sílvia M. Cuco e Mateus Mondin, pelo apoio técnico na utilização do microscópio e à Prof ${ }^{a}$ Dra Margarida L. R. de Aguiar Perecin por colocar seu laboratório à disposição.

Aos colegas do Laboratório de Entomologia, Fitopatologia e Zoologia Agrícola, ESALQ - USP, em especial a Daniela Truffi e ao Prof. Dr. Luiz Eduardo Aranha Camargo pelas facilidades de seqüenciamento.

A todos os professores, alunos e funcionários do Departamento de Genética da ESALQ - USP, pelos ensinamentos e amizade.

Aos funcionários do Setor de Biblioteca Central e do Departamento de Genética da ESALQ - USP, pelos auxílios prestados.

De maneira muito especial, a Reinaldo Montrazi Barata por estar sempre ao meu lado, discutindo os resultados e incentivando nos momentos difíceis. 


\section{SUMÁRIO}

LISTA DE ABREVIATURAS …….............................................. ix

RESUMO

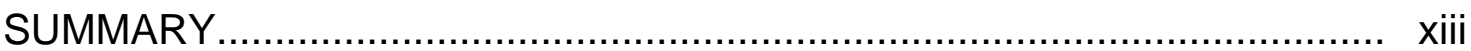

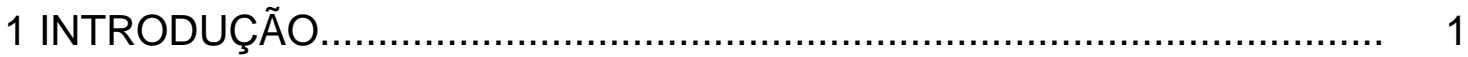

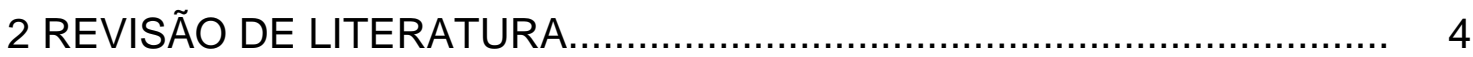

2.1 Importação de proteínas em organelas................................................... 4

2.1.1 Importação de proteínas em cloroplastos.......................................... 5

2.1.2 Importação de proteínas em mitocôndrias......................................... 10

2.1.3 Duplo direcionamento de proteínas................................................. 15

2.1.3.1 Iniciação alternativa da transcrição................................................ 16

2.1.3.2 Pré-mRNA variável................................................................... 17

2.1.3.3 Múltiplos sítios de iniciação da tradução........................................ 17

2.1.3.4 Um único peptídeo bifuncional.................................................. 19

2.2 Mecanismos de regulação do início da tradução em eucariotos.............. 19

2.3 A biossíntese da tiamina em plantas................................................... 22

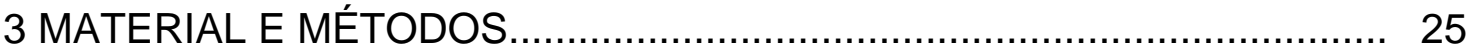

3.1 Localização subcelular da proteína THI1 de Arabidopsis thaliana.......... 25

3.1.1 Construções gênicas....................................................................... 25

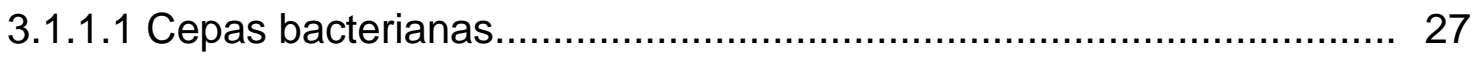

3.1.1.2 Análise dos transformantes ("Screening" por PCR)........................ 27

3.1.1.3 Seqüenciamento dos clones SK(+)THI4-GUS e SK(+)THI27-GUS... 28

3.1.1.4 Meios de cultura................................................................... 29

3.1.2 Transformação de plantas.............................................................. 30 
3.1.3 Análise das plantas transgênicas................................................ 30

3.1.3.1 Teste GUS histoquímico........................................................ 30

3.1.3.2 Extração de DNA de plantas...................................................... 31

3.1.3.3 Reações de PCR..................................................................... 31

3.1.3.4 Fracionamento subcelular.................................................... 31

3.1.3.5 Quantificação de proteínas das frações subcelulares....................... 33

3.1.3.6 Eletroforese e imunodetecção..................................................... 33

3.1.3.7- Quantificação da atividade GUS............................................... 34

3.1.3.8- Gel de atividade GUS............................................................... 34

3.1.4- Preparação de anticorpos policlonais Anti-THI1 .............................. 35

3.1.4.1 Imunização dos animais.......................................................... 35

3.1.4.2 Titulação do soros por "Enzyme Linked Immunosorbent Assay"

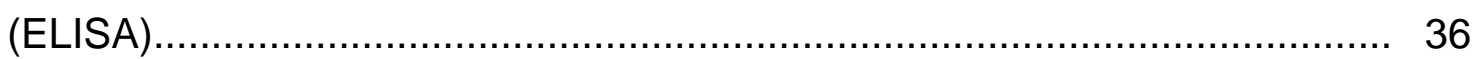

3.1.4.3 Purificação e quantificação dos anticorpos Anti-THI1...................... 37

3.1.4.4 Teste dos anticorpos Anti-THI1 em extratos de plantas................... 37

3.1.4.4.1 Extração de proteínas foliares de N. tabacum e A. thaliana........... 37

3.1.4.4.2 Quantificação de proteínas dos extratos protéicos foliares............. 38

3.1.4.4.3 Teste ELISA......................................................................... 38

3.1.4.4.4 Eletroforese e imunodeteç̧ão................................................... 38

3.1.5 Imunolocalização da proteína THI1 em A. thaliana.............................. 39

3.1.6 Análise de proteção à nuclease S1 ............................................... 40

3.2 Caracterização dos mecanismos de regulação da expressão gênica de thi1 e suas implicações na localização subcelular da proteína....................... 41

3.2.1 Experimentos de transcrição e tradução in vitro................................. 41

3.2.1.1 Construções gênicas................................................................. 41

3.2.1.2 Transcrição e tradução in vitro...................................................... 44

3.2.2 Análise da estrutura secundária do mRNA...................................... 45

3.2.3 Experimentos com "Green Fluorescence Protein" (GFP)................... 45

3.2.3.1 Construções gênicas............................................................. 45

3.2.3.2 Isolamento e eletroporação de protoplastos de N. tabacum.............. 49 


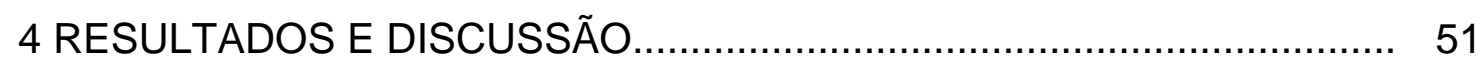

4.1 THI1 apresenta duas seqüências de direcionamento in tandem............ 51

4.2 Um único gene potencialmente codifica as isoformas cloroplástica e

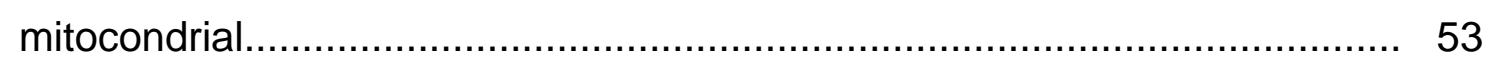

4.3 Efeito da $\alpha$-hélice anfifílica no direcionamento de THI1 às mitocôndrias. 56

4.4 THI1 é codificado por um único transcrito nuclear.................................... 60

4.5 THI1 apresenta dois sítios de iniciação da tradução................................. 63

4.6 A localização subcelular de THI1 é regulada pela iniciação alternativa

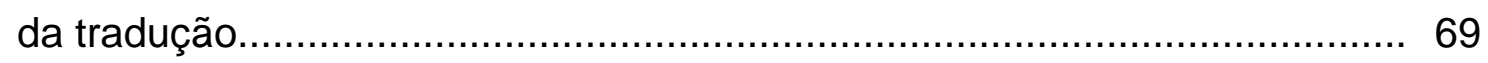

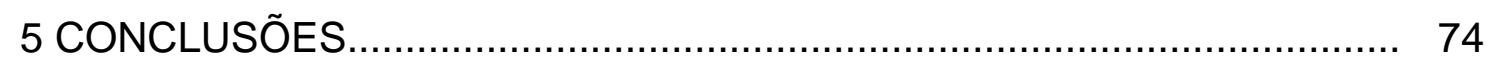

REFERÊNCIAS BIBLIOGRÁFICAS..................................................... 75

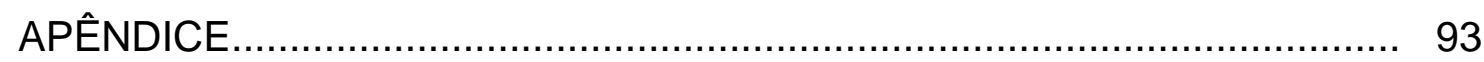




\section{LISTA DE ABREVIATURAS}

ATP $=$ trifosfato de adenosina

$\mathrm{BSA}=$ soro de albumina bovina

cDNA = DNA complementar

$\mathrm{ClpC}=$ chaperona cloroplástica

dNTP = deoxiribonucleotídeo trifosfato

ddNTP = di-deoxiribonucleotídeo trifosfato

EDTA = etilenodiamina tetra acetato dissódico

GFP = proteína verde fluorescente

$\mathrm{GR}=$ glutationa redutase

GTP = trifosfato de guanosina

GUS $=\beta$-glucuronidase

HMPP-PP = 2-metil-4-amino-5-hidroximetilpirimidina pirofosfato

Hsp = proteína de choque térmico, chaperona

$\mathrm{kDa}=$ kilo Dalton

MPP $=$ metalopeptidase

$\mathrm{MSF}$ = fator estimulador da importação mitocondrial

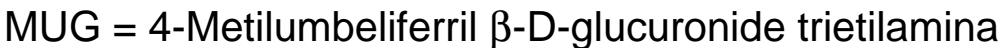

$\mathrm{MU}=$ 7-hidroxi-4-metilcoumarine

PBS = tampão fosfato salino

$\mathrm{PCR}=$ reação de polimerase em cadeia

$(p / v)=$ peso/volume

$\mathrm{PVP}=$ polivinil pirrolidona

rpm $=$ rotações por minuto 
Rubisco $=$ ribulose 1,5 bifosfato carboxilase/oxigenase

SDS $=$ sódio dodecil sulfato

SPP $=$ peptidase de processamento estromal

$\mathrm{SRP}=$ partícula de reconhecimento do sinal

TBS $=$ tampão Tris salino

TH-P = 4-metil-5-(2-hidroxietil)-tiazol monofosfato

TIC = translocase da membrana interna cloroplástica

$\mathrm{TIM}=$ translocase da membrana interna mitocondrial

TMP = tiamina monofosfato

TOC $=$ translocase da membrana externa cloroplástica

TOM = translocase da membrana externa mitocondrial

TPP $=$ tiamina pirofosfato

Tris $=$ Tris(hidroximetil)aminometano

Tween $=$ polioxietilenosorbitol

$\mathrm{X}$-Gluc $=5$-bromo-4-cloro-3-indol $\beta$-D-glucuronide ciclohexilamino 


\section{CARACTERIZAÇÃO DA LOCALIZAÇÃO SUBCELULAR DA PROTEÍNA THI1 DE Arabidopsis thaliana}

Autora: SABRINA MOUTINHO CHABREGAS Orientador: Prof. Dr. MARCIO DE C. SILVA FILHO

\section{RESUMO}

O produto do gene thi1 de Arabidopsis thaliana está provavelmente envolvido na biossíntese de tiamina (vitamina $B_{1}$ ) e na proteção do DNA organelar contra danos. Estudos sobre a biossíntese da tiamina em plantas sugerem uma localização plastidial para este mecanismo, o que está de acordo com a existência de um peptídeo de trânsito cloroplástico (TP) na região $\mathrm{N}$-terminal de THI1. Por outro lado, em leveduras a tiamina é sintetizada em mitocôndrias. Interessantemente, o cDNA de thi1 de $A$. thaliana complementa uma cepa de levedura com disrupção no gene homólogo thi4. A análise da seqüência de aminoácidos de THI1 revelou a presença de uma região capaz de formar uma estrutura do tipo $\alpha$-hélice anfifílica, freqüentemente encontrada em preseqüências mitocondriais, localizada logo após o peptídeo de trânsito cloroplástico. O papel desta região na localização da proteína THI1 nas mitocôndrias foi comprovado a partir de ensaios envolvendo construções de genes quiméricos (contendo ou não a putativa seqüência de direcionamento mitocondrial) e um gene repórter (uidA). Estas construções foram introduzidas 
em plantas de tabaco e a localização da atividade GUS foi determinada nas frações subcelulares das plantas transgênicas. Análise direta da presença de THI1 nas mitocôndrias e cloroplastos de Arabidopsis foi realizada via imunolocalização. Também foram fornecidas evidências que as duas isoformas organelares são codificadas por um único transcrito nuclear. Experimentos de transcrição/tradução in vitro indicaram a ocorrência de dois produtos da tradução a partir de códons de iníciação em fase de leitura. Mutações sítioespecíficas na seqüência de thi1 acoplados à experimentos usando a proteína fluorescente verde (GFP) mostraram que a tradução no primeiro AUG determina a localização da proteína nos cloroplastos, enquanto que a tradução no segundo AUG é responsável pelo endereçamento da proteína às mitocôndrias. A análise do contexto para início da tradução revelou que a região em torno do primeiro AUG é mais favorável para a tradução do mRNA de thi1. Além disso, observou-se a presença de uma forte estrutura em "grampo de cabelo" próximo ao segundo códon AUG, indicando um contexto subótimo capaz de interferir na tradução. Estas observações confirmaram os dados obtidos a partir da tradução in vitro na qual a iniciação se dá preferencialmente no primeiro AUG o que pode sugerir uma maior necessidade da proteína nos plastídeos. 


\title{
CHARACTERIZATION OF THE SUBCELLULAR LOCALIZATION OF Arabidopsis thaliana THIp
}

\author{
Author: SABRINA MOUTINHO CHABREGAS \\ Adviser: Prof. Dr. MARCIO DE C. SILVA FILHO
}

\section{SUMMARY}

Arabidopsis thaliana thi1 gene product is probably involved in both thiamine biosynthesis as well as protection of organellar DNA from damage. Studies of thiamine biosynthesis in plants suggest a plastid location for the pathway, which is in agreement with the predicted THI1 N-terminal chloroplastic transit peptide (TP). On the other hand, thiamine is synthesized in mitochondria in yeast cells. Interestingly, $A$. thaliana thi1 cDNA complements a yeast strain disrupted for the homologous thi4 gene. Analysis of THI1 amino acid sequence revealed the presence of a putative amphiphilic $\alpha$-helix, which is typical for mitochondrial presequences, located downstream of the chloroplast transit peptide. The role of this sequence on mitochondrial import has been shown by chimeric gene constructs (carrying or not the putative mitochondrial presequence) and the uidA reporter gene. These constructions have been introduced into tobacco plants and the GUS activity has been measured in subcellular fractions of transgenic plants. Direct analysis of THIp in mitochondria and chloroplasts has been done via ImmunoGold labelling experiments. 
Additional evidence suggested that the two organellar isoforms were encoded by a single nuclear transcript. In vitro transcription/translation experiments revealed the presence of two translational products by a differential usage of two in-frame translational start codons. Coupling site-specific mutations on THI1 encoding sequence with green fluorescent protein (GFP) gene fusions showed that translation initiation in the first AUG directs translocation of THI1 to plastids. However, when translation initiates from the second AUG THI1 is addressed to mitochondria. Analysis of the translation efficiency of thi1 mRNA revealed that the best context for translation initiation is present at the first AUG. In addition, it has been shown a suboptimal context at the second AUG and a strong stemand-loop structure which is likely to slow translation. These observation confirm the in vitro translation data in which translation occurs preferentially in the first AUG, what could suggest a higher requirement of the protein in plastids. 


\section{INTRODUÇÃO}

O gene thi1, clonado de Arabidopsis thaliana (Machado et al., 1996), codifica uma proteína envolvida na biossíntese de tiamina (vitamina $B_{1}$ ), mais especificamente na formação de um precursor da tiamina: o tiazol. No entanto, o cDNA foi originalmente clonado pela sua capacidade de complementar bactérias deficientes em reparo de DNA. Além disso, Machado et al. (1997) verificaram que THI4 (o homólogo de thi1 em leveduras) está envolvido na proteção do DNA mitocondrial. Portanto, THI1 pode ser considerada uma proteína bifuncional que atua tanto no reparo de DNA quanto na biossíntese de tiamina.

Apesar do mecanismo da biossíntese de tiamina em plantas ainda não ser totalmente conhecido, existem algumas evidências de que ele ocorra em cloroplastos (Belanger et al., 1995). Isto está de acordo com a observação de que a proteína THI1, tanto em $A$. thaliana quanto em milho, é sintetizada com um típico peptídeo de trânsito cloroplástico na extremidade aminoterminal. Interessantemente, os genes thi1 de $A$. thaliana e thi1-1 de milho foram capazes de complementar cepas de levedura deficientes na biossíntese de tiamina (Machado et al., 1997; Belanger et al., 1995). Entretanto, a biossíntese de tiamina em leveduras ocorre em mitocôndrias (Beldwell et al., 1989). Contrariamente, a clonagem de um homólogo ao gene thi1 em Alnus glutinosa (Ribeiro et al., 1996) fez com que os autores tentassem complementar a mesma cepa mutante de levedura, sem sucesso. Estes resultados indicam que as proteínas THI1-1 de milho e THI1 de $A$. thaliana são capazes de ser transportadas às mitocôndrias de levedura. 
A análise da estrutura primária do produto do gene thi1 indica a presença de uma seqüência de direcionamento aos cloroplastos de 55 aminoácidos (Machado et al. 1996). No entanto, um aspecto curioso é a presença de três metioninas numa região imediatamente posterior ao peptídeo de trânsito, sendo que uma delas é altamente conservada em diferentes espécies (Machado et al., 1996), sugerindo um papel fisiológico. A análise desta região revelou a capacidade de formar uma $\alpha$-hélice anfifílica. Curiosamente, esta estrutura secundária é encontrada tipicamente em seqüências de direcionamento mitocondriais.

Pode-se especular que estas metioninas poderiam funcionar como um sítio alternativo de início da tradução. Caso a tradução inicie-se no primeiro ATG (da seqüência de direcionamento), obtêm-se um precursor que poderia ser transportado aos cloroplastos. No caso da tradução iniciar-se em um dos ATGs na parte amino terminal da proteína madura THI1, seria produzida uma proteína sem a seqüência de direcionamento para o cloroplasto, podendo então ser direcionada a outro compartimento subcelular (mitocôndrias, por exemplo). Ou então, o peptídeo de trânsito cloroplástico seja capaz de direcionar a proteína às mitocôndrias e cloroplastos simultaneamente. Isto não seria inesperado, uma vez que Creissen e colaboradores (1995) observaram um direcionamento simultâneo a estas organelas da glutationa redutase, enzima envolvida num sistema de resposta ao estresse oxidativo.

Geralmente, o processo de importação de proteínas é específico para cada organela (Boutry et al., 1987; Schmitz \& Lonsdale, 1989; Chaumont et al., 1990; Silva-Filho et al., 1996; Barata, et al., 2000). No entanto, casos de direcionamento inespecífico podem ser encontrados na literatura (Hurt et al., 1986; Pfaller et al., 1989; Franzén et al., 1990; Huang et al., 1990; Brinck et al., 1994; Chow et al., 1997; Silva-Filho, 1999). Porém, a maioria deles trata-se de sistemas de importação heterólogos ou baseados em seqüências de direcionamento atípicas. 
Diversas proteínas presentes nas células eucarióticas desempenham suas funções em mais de um compartimento subcelular. Para tanto, as células eucarióticas desenvolveram mecanismos de direcionamento de proteínas com funções semelhantes para as diferentes localizações dentro da célula.

A alternativa mais utilizada é a existência de vários genes que codificam isoformas com seqüências de direcionamento distintas (Gietl, 1992; Danpure, 1995). Em casos menos freqüentes, um apurado sistema de controle da expressão gênica entra em ação, permitindo que um único gene codifique proteínas que apresentam seqüências de direcionamento distintas para cada compartimento. Geralmente, é observada a permanência da proteína no citosol e o direcionamento para uma organela. Apesar de bastante raro, 0 direcionamento de uma mesma proteína para duas organelas tem sido observado (Danpure, 1995; Wimmer et al., 1997; Small et al., 1998; Akashi et al., 1998; Huang et al., 1999; Hedtke et al., 2000; Duchêne et al., 2001; Watanabe et al., 2001).

O estudo destes casos é bastante interessante uma vez que permite um maior entendimento dos processos de regulação de que a célula eucariótica dispõe para controlar a expressão de seus genes. 


\section{REVISÃO DE LITERATURA}

\subsection{Importação de proteínas em organelas}

O complexo sistema de endomembranas permitiu a compartimentalização dos diversos processos fisiológicos e bioquímicos da célula eucariótica, tornando uma de suas características mais importantes. Esta rede de membranas deu origem aos sub-compartimentos celulares ou organelas responsáveis por processos metabólicos específicos.

Alguns destes compartimentos possuem seu próprio genoma, como os plastídeos e as mitocôndrias, mas de uma maneira geral, as organelas importam suas proteínas do citosol. Assim, a maior parte das proteínas que têm suas funções nas organelas, são codificadas por genes nucleares e sintetizadas nos ribossomos citosólicos sob a forma de um precursor, que apresenta um peptídeo sinal encarregado do seu direcionamento até sua localização final (Adams et al., 2000; Bauer et al., 2001).

O processo de importação é específico para cada compartimento subcelular. Alguns exemplos dessa especificidade são considerados a seguir:

- Proteínas direcionadas para as mitocôndrias apresentam na extremidade amino terminal uma seqüência de direcionamento em $\alpha$-hélice anfifílica, composta por aminoácidos hidrofóbicos de um lado, e do outro aminoácidos carregados positivamente (Glaser et al., 1998);

- Por outro lado, as proteínas que devem ser direcionadas para os cloroplastos possuem um peptídeo de trânsito, também amino-terminal, com estrutura secundária do tipo "espiral ao acaso" (Soll \& Tien, 1998); 
- Proteínas redirecionadas para o núcleo apresentam sinais pequenos de 4 a 8 aminoácidos básicos localizados em diferentes posições da cadeia polipeptídica (Bar-Peled et al., 1996);

- O direcionamento para os peroxissomos, na maior parte dos casos, é dado por seqüências SKL (serina, lisina e leucina) carboxi-terminais (Subramani, 1996);

- Para a via secretória ("secretory pathway"), ou seja, proteínas direcionadas para o retículo endoplasmático (RE), aparato de Golgi, membrana plasmática, vesículas de curta duração, além de algumas proteínas vacuolares e proteínas secretadas, duas seqüências de direcionamento ao RE foram identificadas: os peptídeos sinais (PS) são aqueles clivados a partir de uma cadeia nascente, e as âncoras sinais (AS), que não são clivadas liberando as proteínas na membrana do RE. Além disso, existem alguns "fatores chaves" e SRPs (Partículas de Reconhecimento do Sinal) (Bar-Peled et al., 1996; Corsi \& Schekman, 1996).

\subsubsection{Importação de proteínas em cloroplastos}

As células das plantas constituem um interessante sistema no qual a informação genética encontra-se localizada em 3 diferentes compartimentos intracelulares: núcleo, plastídeos e mitocôndrias (Glaser et al., 1998). No entanto, a capacidade codante dos genomas de mitocôndrias e dos plastídeos, notadamente os cloroplastos, é muito limitada, uma vez que seus genes foram sendo transferidos para o núcleo durante a evolução.

Os cloroplastos retém ainda uma capacidade reduzida de codificar 100 a 200 proteínas de um total de aproximadamente 3200 presentes em cianobactérias, seus ancestrais mais prováveis (Bruce, 2000). Assim, cerca de 90\% das proteínas cloroplásticas são codificadas por genes nucleares e sintetizadas nos ribossomos citosólicos sob a forma de grandes precursores (denominadas preproteínas). 
Conforme citado anteriormente, a seqüência de direcionamento para os cloroplastos localiza-se na extremidade amino-terminal da proteína e denomina-se peptídeo de trânsito com estrutura secundária do tipo "espiral ao acaso" (von Heijni et al., 1989; Claros \& Vincens, 1997). O tamanho varia de 20 a 120 resíduos de aminoácidos e apresentam basicamente três regiões distintas (Bruce, 2000):

- uma região amino-terminal não carregada de aproximadamente 10 resíduos, geralmente começando com metionina seguida de alanina e terminando com glicina e prolina;

- um domínio central, onde faltam resíduos ácidos mas enriquecido de serina e treonina;

- uma região carboxi-terminal rica em argininas e que potencialmente forma uma estrutura $\beta$-pregueada anfifílica, com aproximadamente 10 resíduos.

Existem evidências (Walgemann \& Soll, 1996) de que o sucesso da importação nos cloroplastos depende da fosforilação de um resíduo de serina ou treonina (em negrito) do peptídeo de trânsito inserida no contexto: $\mathrm{P} / \mathrm{GX} \mathrm{X}_{\mathrm{n}} \mathrm{R} / \mathrm{KX}_{\mathrm{n}} \mathrm{S} / \mathrm{TX}_{\mathrm{n}} \mathrm{S}^{*} / \mathrm{T}^{*}$.

Fatores citosólicos, como por exemplo a proteína 14-3-3, interagem com o peptídeo de trânsito fosforilado, conduzindo a preproteína até o aparato de importação presente na membrana organelar (May \& Soll., 2000). Para eficiente importação é necessária a defosforilação do peptídeo de trânsito assim que ele é reconhecido na membrana cloroplástica (Walgemann \& Soll, 1996; Bruce, 2000).

Lipídeos presentes nas membranas dessas organelas também desempenham um importante papel no processo de importação (Bruce, 1998).

Os cloroplastos são envoltos por um sistema duplo de membranas, no qual localizam-se complexos de translocação de proteínas

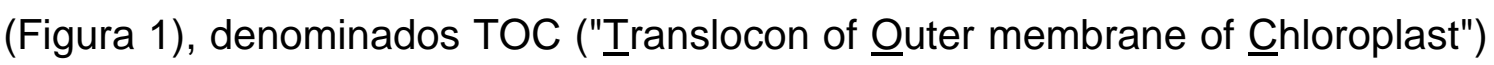


para membrana externa e TIC ("Translocon of Inner membrane of $\underline{\text { Chloroplast") }}$ na membrana interna.

As proteínas que compõem estes complexos de importação são denominadas pelas siglas TOC ou TIC, de acordo com a sua localização na membrana externa ou interna respectivamente, seguidas do peso molecular da proteína. A maioria delas já foi caracterizada e têm função conhecida (Soll \& Tien, 1998):

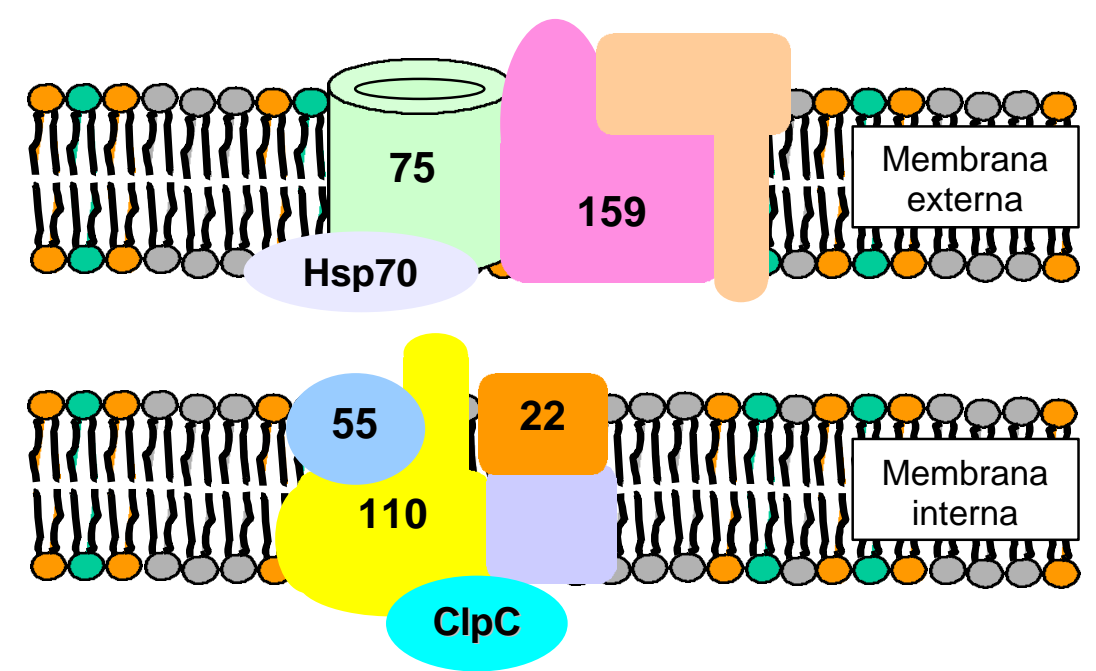

Figura 1 - Complexos de importação de proteínas localizados nas membranas externa (TOC) e interna (TIC) dos cloroplastos (adaptado de Keegstra \& Cline, 1999).

- TOC159 (antigo TOC86): funciona como um receptor para precursores ou é uma subnidade essencial de um complexo receptor oligomérico. Contém sítios distintos de ligação à ATP e GTP e constitui a maior fosfoproteína da membrana envelope externa. É regulado em vários níveis por proteínas quinases (Soll \& Tien, 1998; Chen et al., 2000); 
- TOC75: é o maior componente inserido na membrana externa por 16 domínios hidrofóbicos. Provavelmente forma o poro de translocação, pois apresenta capacidade eletroforética (Soll \& Tien, 1998);

- TOC34: outra das principais proteínas da membrana envelope externa. Representa um novo tipo de proteína de ligação ao GTP, enquanto que o domínio carboxi-terminal é responsável pelo "ancoramento" na membrana (Soll \& Tien, 1998);

- TIC110: a sua função precisa ainda não foi determinada, no entanto algumas evidências sugerem que seu domínio carboxi-terminal hidrofílico, exposto para o lado estromal, reaja com chaperonas cloroplásticas, especificamente ClpC (Keegstra \& Cline, 1999);

- TIC55: proteína que contém um centro de ferro-enxofre. No entanto, o papel deste centro redox ainda não está claro (Keegstra \& Cline, 1999);

- TIC20 e 22: encontram-se fortemente ligados à preproteína que sofre translocação. TIC20 parece ser uma proteína de membrana, enquanto TIC22 é uma proteína periférica que serve para conectar os complexos da membrana externa aos da membrana interna (Keegstra \& Cline, 1999);

- Chaperonas moleculares: várias chaperonas presentes em cloroplastos são candidatas a um papel no mecanismo de importação de proteínas. Com70 (Hsp70), encontrada na superfície citoplasmática da membrana externa parece estar envolvida nos estágios iniciais da translocação (Kourtz \& Ko, 1997). Outra Hsp70 têm sido identificada no espaço intermembrana e parece ser responsável por uma atividade de manter a preproteína desdobrada durante o processo. Esta capacidade provê uma força dirigindo o transporte da preproteína através do envelope externo e desse para a membrana interna (Scott \& Theg, 1996). Chaperonas moleculares estromais dirigem a importação dentro do estroma, puxando a preproteína para o interior do cloroplasto através de repetidos ciclos de ligação e desassociação. Associa-se ao complexo TIC uma ClpC estromal da família das chaperoninas Hsp100 (Keegstra \& Cline, 1999). 
Após a translocação, ocorre o processamento proteolítico do peptídeo de trânsito por SPPs ("Śtromal Processing Peptidases") (Richter \& Lamppa, 1999). Uma enorme quantidade de preproteínas é importada nos cloroplastos (cerca de $2 \times 10^{7}$ moléculas de LHCP, "light harvesting complex protein", são importadas in vivo em 24 horas) (Pfisterer et al., 1982). Como cada uma dessas proteínas apresenta um peptídeo de trânsito, que é removido e não fica acumulado no interior dos cloroplastos, deve haver um mecanismo de degradação proteolítica encarregado de eliminá-los seletivamente. Esta atividade é ATP-dependente, sugerindo que os cloroplastos possuem um requerimento de energia especialmente destinado para reciclagem dos peptídeos de trânsito. SSP liga-se ao peptídeo de trânsito, clivando-o a subfragmentos que são reconhecidos e degradados a aminoácidos por uma metalopeptidase (MPP) solúvel, dependente de ATP (Richter \& Lamppa, 1999).

Além do mecanismo geral de direcionamento estromal mencionado acima, existem outras possíveis destinações das preproteínas no interior dos cloroplastos. São seis localizações possíveis, a saber: membrana envelope externa, espaço intermembranas, membrana interna, estroma, membrana tilacóide e lúmem do tilacóide.

Proteínas destinadas à membrana externa podem inserir-se diretamente, sem hidrólise de ATP, como no caso de TOC34, que não apresenta um peptídeo sinal amino-terminal (Li \& Chen, 1997). Um outro caminho é o seguido por TOC75, que contém uma seqüência amino-terminal "bipartite" (Tranel \& Keegstra, 1996). A primeira parte desta seqüência é clivada no estroma, enquanto que a segunda corresponde a um sinal de paralisação da translocação na membrana externa, removido posteriormente por uma protease não identificada (Keegstra \& Cline, 1999).

No mecanismo de translocação para a membrana interna, a proteína é levada até o estroma e depois entregue à sua localização final, ou apresenta um sinal de paralisação da translocação como descrito no caso anterior (Keegstra \& Cline, 1999). 
O direcionamento de proteínas para tilacóides segue rotas diferentes. A inserção na membrana tilacoidial pode ser alcançada espontaneamente ou por uma via dependente de SRP54 (partícula reconhecedora de sinal), semelhante a encontrada no mecanismo de direcionamento para retículo endoplasmático (Robinson et al., 1998; Dalbey \& Robinson, 1999).

Proteínas são direcionadas para o lúmem do tilacóide via peptídeo de trânsito "bipartite". A primeira parte dele encarrega-se do direcionamento até - estroma, onde é clivado para expor a segunda parte que direciona a preproteína até o tilacóide. Dois mecanismos parecem agir neste tipo de direcionamento, um dependente de $\Delta \mathrm{pH}$ (proteínas importadas por este caminho apresentam uma dupla arginina em seu peptídeo sinal, essencial para a translocação) e outro dependente de SecA (uma proteína homóloga `a proteína secretória SecA bacteriana) (Robinson et al., 1998; Dalbey \& Robinson, 1999).

\subsubsection{Importação de proteínas em mitocôndrias}

São muitas as semelhanças existentes entre mitocôndrias e cloroplastos. As duas organelas são envolvidas por um sistema duplo de membranas que, geralmente precisa ser atravessado pelas preproteínas. Assim, os complexos de translocação de preproteínas presentes nas membranas dessas organelas são estrutural e funcionalmente distintos de qualquer outro no interior da célula (Gabriel et al., 2001). Ambas as organelas possuem seu próprio material genético, no entanto a maioria de seus genes foram transferidos para o núcleo. No fungo Saccharomyces cerevisiae, as mitocôndrias contêm um sistema funcional para a síntese de apenas 8 cadeias polipeptídicas enquanto que cerca de 400 a 500 proteínas são importadas do citosol (Ryan et al., 2000). 
Normalmente, a seqüência de direcionamento de proteínas direcionadas para as mitocôndrias, denominada preseqüência, apresenta uma estrutura em $\alpha$-hélice anfifílica, com aminoácidos hidrofóbicos distribuídos de um lado da hélice e aminoácidos carregados positivamente do outro (von Heijne et al., 1989; Claros \& Vincens, 1997).

Como no caso dos cloroplastos, as mitocôndrias apresentam localizações distintas para suas proteínas: membrana externa, espaço intermembranas, membrana interna e matriz mitocondrial.

Fatores citosólicos e chaperonas moleculares participam do processo de importação mitocondrial. Uma Hsp70 citosólica interage com polipeptídeos recém-sintetizados. Outras chaperonas também podem promover a importação pela apresentação do precursor em uma conformação que permita ligação ao complexo de importação localizado na membrana externa da organela. A melhor caracterizada é MSF ("Mitochondrial Śtimulator Factor"), uma proteína 14-3-3 que se liga a vários precursores mitocondriais (Lithgow, 2000).

Os complexos de importação de proteínas localizados nas duas membranas (Figura 2) que envolvem a organela são denominados TOM ("Translocase of Outer membrane of Mitochondria") e TIM ("Iranslocase of Inner membrane of Mitochondria") e a maioria de seus componentes protéicos encontra-se descrita na literatura:

- TOM20 e 22: são receptores ácidos cuja função é ligar-se às preseqüências (Lithgow, 2000);

- TOM37 e 70: interagem com outras partes da preproteína, talvez refletindo uma habilidade em capturar polipeptídeos de chaperonas citossólicas como MSF (Lithgow, 2000);

- TOM40: constitui o canal de importação. Acredita-se que TOM20 e TOM 70 ancorem os precursores levando-os ao canal de translocação (Lithgow, 2000); 
- TOM5, 6 e 7: são pequenas proteínas que auxiliam na formação do canal, juntamente com TOM40 (Koehler, 2000);

- TIM23: mediador da translocação para dentro da matriz. Aparentemente, TIM23 forma um dímero na ausência de um potencial de membrana, que fecha a passagem pela membrana interna. A ligação do precursor no domínio de TIM23 localizado no espaço intermembranas, desencadeia a dissociação do dímero, permitindo a passagem do precursor através do canal de importação (Koehler, 2000);

- TIM17: forma um complexo com TIM23 de aproximadamente 90kDa (Koehler, 2000);

- TIM44, mHsp70 e GrpE: também fazem parte do "motor de translocação" da membrana interna mitocondrial (Koehler, 2000).

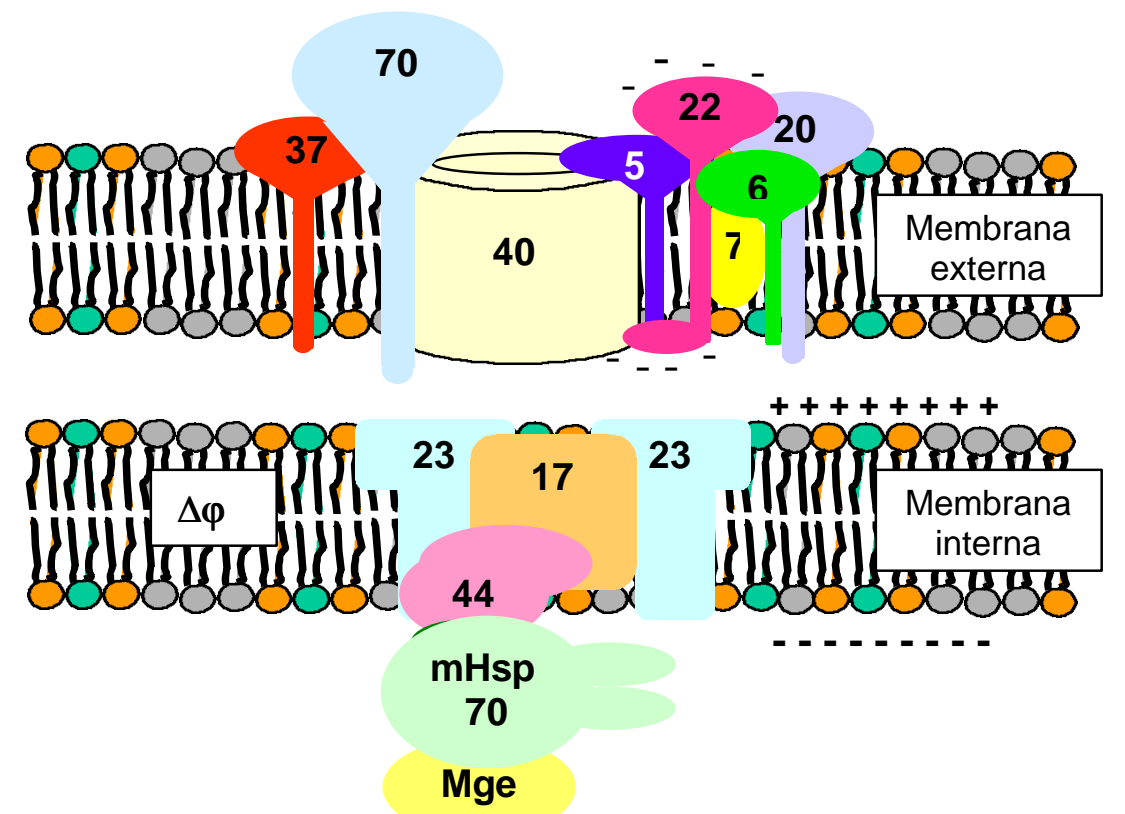

Figura 2 - Complexos de importação de proteínas localizados nas membranas externa (TOM) e interna (TIM) das mitocôndrias (adaptado de Glaser et al., 1998). 
As proteínas que devem ser inseridas na membrana interna mitocondrial, percorrem um outro caminho, composto por diferentes proteínas (Figura 3):

- TIM22, 54 e 18: formam um complexo de aproximadamente $300 \mathrm{kDa}$ no espaço intermembranas, que é mediador da inserção de proteínas na membrana interna (Koehler, 2000);

- TIM8, 9, 10, 12 e 13: são denominadas "minúsculas TIMs" e constituem uma família de pequenas proteínas, que requerem zinco para sua função in vivo (Koehler, 2000)

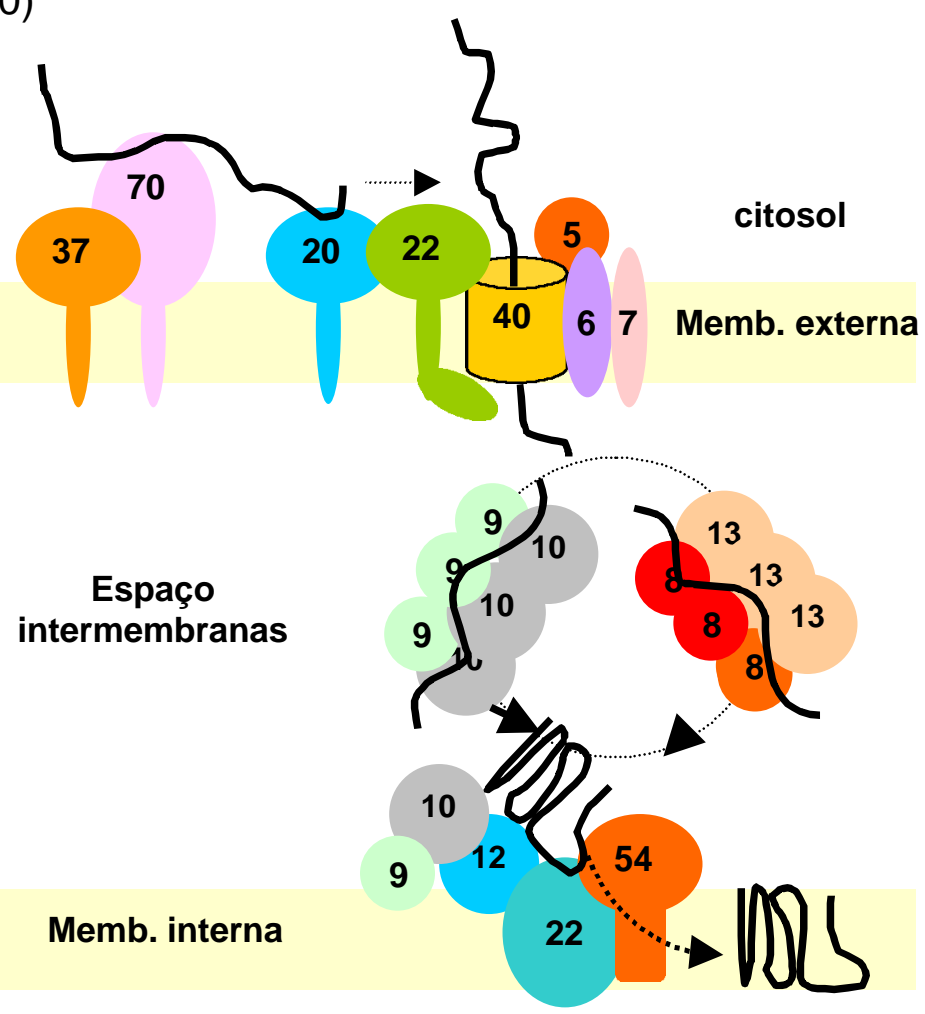

Figura 3 - Complexo de importação de proteínas para a membrana interna mitocondrial (adaptado de Koehler et al., 1999). 
O processo de importação mitocondrial é reversível até o último estágio, podendo ocorrer em ambas as direções, indicando que o poro em si não provê nenhuma direcionalidade. Dessa forma, a translocação deve ser acoplada a forças exergônicas que conferem direcionalidade (Herrmann \& Neupert, 2000). Duas alternativas têm sido propostas: (i) a maquinaria de translocação pode trabalhar como um motor (Mahadevan \& Matsudaira, 2000), que em geral emprega uma variedade de fontes de energia e (ii) a flutuação do polipeptídeo no poro de translocação pode ser convertida em um movimento unidirecional (Simon et al., 1992).

O primeiro modelo propõe que $\mathrm{mHsp} 70$, localizada na matriz mitocondrial, pode funcionar como um motor. A hidrólise de ATP causa uma mudança conformacional intramolecular na $\mathrm{mHsp} 70$ levando a um poderoso movimento que "puxa" a preproteína para o interior da organela (Glick, 1995). O outro modelo é denominado "Modelo Browniano" e propõe que a proteína mHsp70 realiza várias ligações ao precursor, com gasto de ATP, o que faz com que o processo de importação adquira um movimento unidirecional (Wachter et al., 1994).

O potencial de membrana presente na membrana interna mitocondrial (positivo do lado de fora e negativo do lado de dentro) também possui papel significativo no processo de importação. Aparentemente este potencial proporciona um efeito eletroforético, uma vez que a preseqüência é dotada de cargas positivas em um dos lados da $\alpha$-hélice, que conduzem a preproteína para dentro da matriz (Herrmann \& Neupert, 2000).

Após a importação da preproteína na matriz, ocorre o processamento proteolítico da seqüência de direcionamento organelar por metalopeptidases: MPPs (Mitochondrial Processing Peptidases) da célula (Gabriel et al., 2001). As MPPs são compostas por duas subunidades estruturalmente relacionadas e que trabalham em conjunto para a remoção da preseqüência (Braun \& Schmitz, 1997). 


\subsubsection{Duplo direcionamento de proteínas}

Alguns processos metabólicos realizam-se em mais de um local dentro da célula, como por exemplo a síntese de DNA e RNA no núcleo, mitocôndrias e cloroplastos e a $\beta$-oxidação dos ácidos graxos nos peroxissomos e mitocôndrias de células animais (Danpure, 1995). Para estes casos, as células eucarióticas têm desenvolvido uma série de mecanismos de direcionamento de proteínas com funções semelhantes para as diferentes localizações intracelulares.

O mecanismo mais comum é a existência de vários genes que codificam para proteínas semelhantes, cada qual com seu peptídeo sinal específico. Este é o caso da enzima protoporfirinogênio IX oxidase, que apresenta duas isoformas, uma direcionada para a mitocôndria e outra para o cloroplasto, encarregadas de catalisar a reação de conversão do protoporfirinogênio IX a protoporfirina, no último passo comum das vias de síntese de grupo heme e clorofila (Lermontova, et al., 1997).

Raramente são observadas situações nas quais um único gene codifica para duas ou mais proteínas diferentes, sendo que cada uma apresenta uma localização subcelular específica (Danpure, 1995; Small et al., 1998). Mais comumente é observado o direcionamento para uma organela e para o citosol. $\mathrm{O}$ direcionamento para duas organelas é mais raro. Alguns dos mecanismos que tornam esse processo possível podem dispor de múltiplos transcritos (produzidos por meio da existência de vários sítios de iniciação da transcrição ou pelo processamento variável do $\mathrm{mRNA}$ ) ou de um único transcrito (provido de múltiplos sítios de iniciação da tradução ou uma proteína com direcionamento ambíguo) (Danpure, 1995). 


\subsubsection{Iniciação alternativa da transcrição}

Um único gene apresenta diferentes sítios de iniciação da transcrição e consequentemente vários transcritos que podem ser diferenciados devido à presença ou ausência de uma seqüência de direcionamento $\mathrm{N}$ terminal (Figura 4). Este é o caso da Hsp70 plastidial e glioxissomal de cotilédones de melancia (Wimmer et al., 1997).
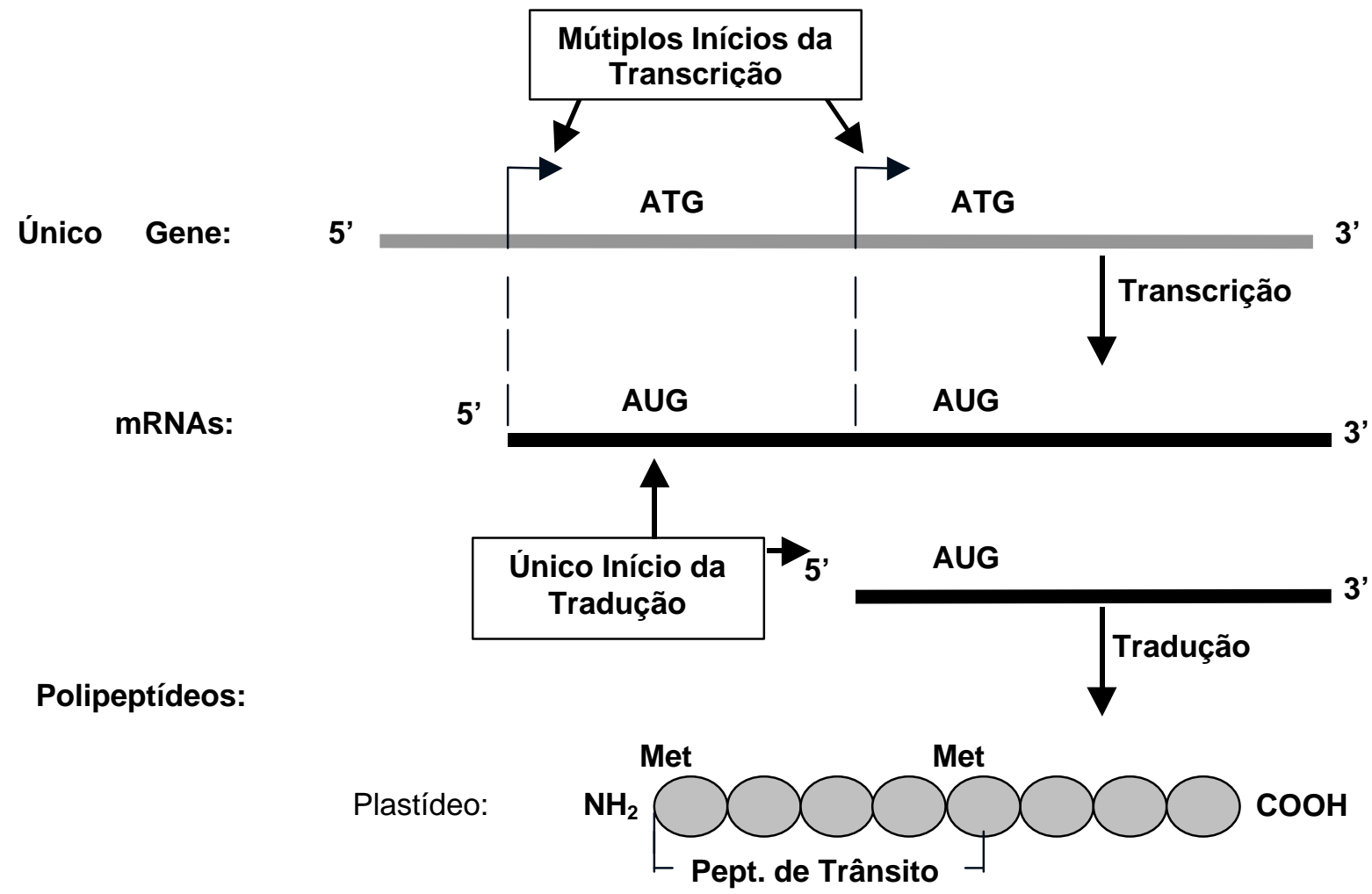

Peroxissomo:

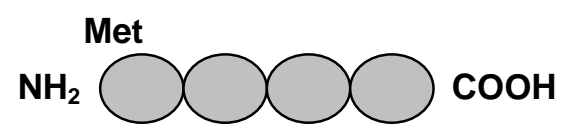

Figura 4 - Mecanismo de Controle por Iniciação Alternativa da Transcrição (adaptado de Danpure, 1995). 
Em cotilédones de melancia, um único gene foi encontrado codificando para as formas glioxissomal e plastidial de uma Hsp de $70 \mathrm{kDa}$. Análises de moléculas de mRNA de diferentes tamanhos produzidos a partir do gene desta Hsp70 revelaram a existência de 2 "metioninas iniciais" em fase de leitura, conduzindo para dois tipos de proteínas precursoras: um grande polipeptídeo, exibindo uma seqüência de direcionamento amino-terminal que funciona como um sinal de importação para plastídeos e uma versão mais curta desta seqüência que dirige a Hsp70 para dentro dos peroxissomos com um sinal do tipo SKL que se torna funcional quando a tradução se inicia na segunda metionina inicial.

\subsubsection{Pré-mRNA variável}

Um mRNA pode ser processado de várias formas, resultando em diferentes transcritos que possuem informações de direcionamento distintas localizadas em qualquer região da proteína.

Em plantas existe um único relato sobre este mecanismo (lan Small, comunicação pessoal), mas podem ser encontrados em Saccharomyces cerevisiae e em humanos. Um exemplo bastante interessante é o que ocorre com a cadeia pesada da imunoglobulina $\mu$ (Peterson \& Perry, 1986), que pode ser secretada pelos linfócitos maduros ou ficar retida na membrana (em linfócitos iniciais). Esta localização variável é devida à combinação de clivagem ou "splicing" alternativo do transcrito primário.

\subsubsection{Múltiplos sítios de iniciação da tradução}

Outro mecanismo pelo qual variabilidade pode ser introduzida dentro da extremidade amino-terminal de um polipeptídeo é a iniciação alternativa da tradução a partir de um único transcrito (Danpure, 1995). Embora 
o mecanismo seja diferente daquele da iniciação alternativa da transcrição, o resultado é o mesmo (Figura 5).

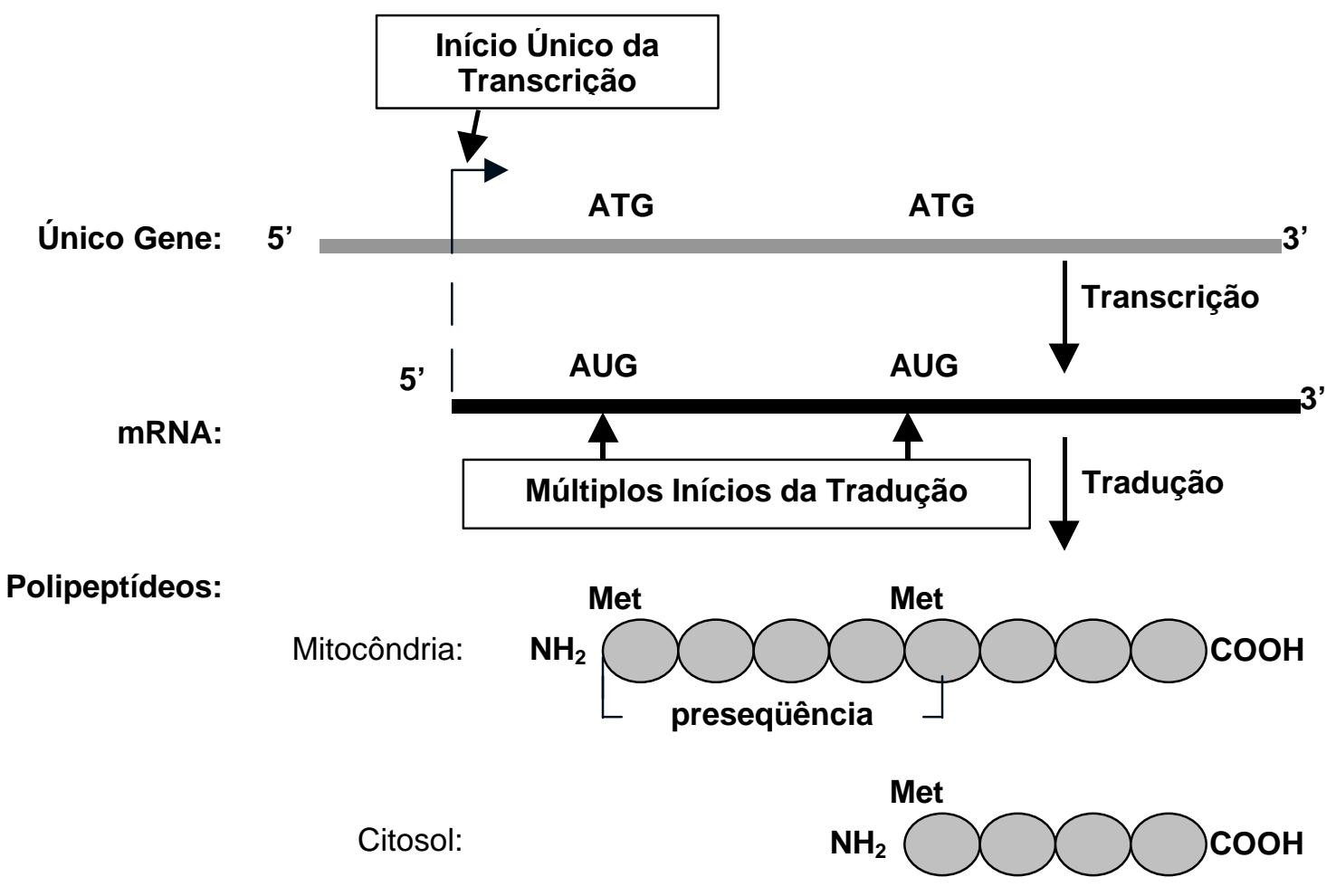

Figura 5 - Mecanismo de Controle por Iniciação Alternativa da Tradução (adaptado de Danpure, 1995).

Novamente, existem obrigatoriamente 2 sítios potenciais de iniciação da tradução em fase de leitura. A iniciação da tradução no primeiro sítio produz um longo peptídeo possuindo uma seqüência de direcionamento amino-terminal, enquanto o início da tradução no segundo sítio, produz um polipeptídeo curto no qual a seqüência de direcionamento está ausente. Este mecanismo pode explicar facilmente a localização das formas mitocondrial e 
citosólica da enzima alanil-tRNA-sintetase em Arabidopsis thaliana (Mireau et al., 1996).

Recentemente, foi descrito por Watanabe e colaboradores (2001) o primeiro caso em plantas de duplo direcionamento de uma proteína para mitocôndrias e cloroplastos envolvendo este mecanismo de regulação. Alguns fatores estruturais do mRNA regulam a iniciação da tradução em organismos eucariotos (Kozak, 1991a) e serão detalhados mais adiante.

\subsubsection{Um único peptídeo bifuncional}

Existem ainda casos em que uma única seqüência de direcionamento é reconhecida pela maquinaria de importação de duas organelas diferentes. É o que acontece com as formas mitocondriais e cloroplásticas da glutationa redutase (GR) de ervilha in vivo (Creissen et al., 1995) e com as formas mitocondriais e cloroplásticas da Ferroquelatase-I de Arabidopsis thaliana, in vitro (Chow et al., 1997). Entretanto, é importante ressaltar que estudos sobre a especificidade de importação in vitro devem ser interpretados com precaução (Silva-Filho et al., 1997).

Caso semelhante foi verificado com a metionil-tRNA-sintetase de A. thaliana (Menand et al., 1998) no qual os autores concluíram que o peptídeo de trânsito desta proteína contém informações suficientes para direcionamento tanto para cloroplastos quanto para mitocôndrias e representa uma classe de "sinais de direcionamento ambíguos", cuja estrutura permite interagir com receptores na superfície de ambas as organelas.

\subsection{Mecanismos de regulação do início da tradução em eucariotos}

A fase de iniciação da síntese de proteínas nada mais é do que a reunião dos componentes que polimerizarão aminoácidos (Kozak, 1999). A 
síntese de proteínas é normalmente regulada na iniciação da tradução, o que faz com que esta fase mereça especial atenção.

Em organismos eucariotos o processo de tradução é bastante complexo, envolvendo diversos fatores traducionais, além dos ribossomos, compostos por duas subunidades, uma menor (40S) e uma maior (60S). No mecanismo de iniciação da tradução, a pequena subunidade ribossomal $40 \mathrm{~S}$ normalmente entra, não diretamente no códon AUG, mas à região 5' do mRNA (Kozak, 1999). A tradução é fortemente dependente da estrutura "5' m7G cap" na extremidade 5' do mRNA eucarioto, que é reconhecida pela subunidade menor do ribossomo (40S). A subunidade 40S, carregando o Met-tRNA, e outros fatores traducionais, movimenta-se ao longo da região $5^{\prime}$ não traduzida (5'-UTR) do mRNA até encontrar o primeiro AUG ("scanning model"), onde permanece "estacionada", até que a subunidade 60S junte-se a ela para iniciar a tradução (Kozak, 1999).

Existem algumas características presentes em mRNAs que regulam a ocorrência de iniciação da tradução. Dentre elas, a mais importante seria o contexto ao redor do AUG (Kozak, 1991a). Em plantas, a seqüência consenso é AACAAUGGC (Lütcke et al., 1987; Joshi et al., 1997), sendo que os aminoácidos nas posições -3 e +4 são os mais importantes (tomando-se o $A$ do códon AUG como +1). Recentemente, Lukaszewicz et al. (2000), propuseram que, especificamente para tabaco, o melhor contexto é A/GAAAUGGC. Kozak (1991b) relata que a análise de 252 mRNAs de plantas revelou que 93\% apresentam uma purina na posição -3 , e $74 \%$ têm um G na posição +4. Além disso, mutações pontuais na seqüência contexto ao redor do AUG alteram a eficiência de iniciação da tradução pelos ribossomos eucarióticos (Kozak, 1986).

O comprimento da seqüência 5'-UTR, ou seja, anterior à região codante do mRNA, também é importante. Ela deve possuir de 17 a 80 nucleotídeos para eficiente tradução (Kozak, 1991a). 
No caso de existir mais de um códon de iniciação da tradução $(A \cup G)$, o início se dá principalmente no primeiro deles (regra do primeiro AUG). No entanto, se o primeiro AUG apresentar um contexto ruim (sem a purina a -3 e um $\mathrm{G} \mathrm{a} \mathrm{+4)} \mathrm{para} \mathrm{iniciação} \mathrm{da} \mathrm{tradução,} \mathrm{a} \mathrm{subunidade} 40 \mathrm{~S}$ pode passar direto por ele indo parar preferencialmente no segundo AUG, onde inicia a tradução (Kozak, 1995).

No entanto, a estrutura secundária adotada pelo mRNA também interfere na iniciação da tradução. Dependendo da estrutura formada, um primeiro AUG, mesmo inserido em um bom contexto, pode não estar acessível aos ribossomos e a tradução inicia-se no segundo AUG (Kozak, 1999). A estrutura secundária do mRNA, interfere tanto de forma positiva quanto negativa para determinar o sítio para iniciação da tradução. Estudos indicam que uma estrutura secundária em forma de "grampo" localizada a 12 ou 15 nucleotídeos após o códon AUG causa uma parada momentânea da subunidade ribossomal $40 \mathrm{~S}$ exatamente sobre o centro de reconhecimento do AUG, facilitando a iniciação da tradução. No entanto, uma pequena quantidade de estruturas secundárias próximas ao "cap" (nos primeiros 12 nucleotídeos) podem inibir drasticamente a tradução (Kozak, 1991a).

A ocorrência de início da tradução interna em mRNAs virais e mais recentemente em outros mRNAs celulares têm sido objeto de intenso debate (Kozak, 2001). Nestes casos, a presença de sítios internos de entrada dos ribossomos (IRES) na região 5'-UTR de mRNAs permitiria a tradução na ausência do capacete (cap) na extremidade 5' do mRNA (Jang et al., 1988; Pelletier \& Sonemberg, 1988). A ocorrência de IRES em outros sistemas celulares foi criticamente analisada recentemente, sugerindo inconsistência em alguns estudos o que a tornaria significativamente menos comum (Kozak, 2001). 


\subsection{A biossíntese da tiamina em plantas}

Tiamina (vitamina $\mathrm{B}_{1}$ ) atua como cofator essencial requerido para a atividade de várias enzimas associadas a processos metabólicos importantes, incluindo o ciclo do ácido cítrico, a glicólise, a biossíntese de pigmentos e o ciclo da pentose fosfato (Belanger et al., 1995; Kim et al., 1998).

Estudos genéticos e bioquímicos em microrganismos, assim como Escherichia coli e leveduras, revelaram alguns passos da via biossintética da tiamina (Begley, 1996; Miranda-Ríos et al., 2001). Nestes organismos, a síntese desta vitamina ocorre através de duas vias independentes que sintetizam os grupos tiazol e pirimidina dando origem à tiamina. Os produtos finais dessas duas vias, 2-metil-4-amino-5-hidroximetilpirimidina pirofosfato (HMP-PP) e 4metil-5-(2-hidroxietil)-tiazol monofosfato (TH-P), são condensados pela tiaminafosfato pirofosforilase (TMP-PPase) para produzir tiamina monofosfato (TMP). TMP é então processada à tiamina pirofosfato (TPP), a forma ativa como cofator. A biossíntese de tiamina envolve no mínimo 10 passos enzimáticos e vários genes envolvidos no processo têm sido clonados em microrganismos (Begley, 1996).

No entanto, o conhecimento do mecanismo da biossíntese de tiamina em plantas superiores ainda é incipiente. Algumas análises bioquímicas de intermediários e estudos com mutantes genéticos sugerem que as plantas provavelmente utilizam uma via similar àquela de $E$. coli e leveduras, descrita anteriormente (Kim et al., 1998).

Dois genes (thi1-1 e thi1-2) envolvidos na biossíntese do grupo tiazol foram isolados em milho (Belanger et al., 1995). Estes genes codificam proteínas similares à THI4 de Saccharomyces cerevisiae (Praekelt et al., 1994). Mais recentemente, dois outros homólogos ao gene thi4 foram isolados de Alnus glutinosa (agthi1) (Ribeiro et al., 1996) e Arabidopsis thaliana (thi1) (Machado et al., 1996). 
Em plantas superiores, a síntese do tiazol ocorre em plastídeos a partir de 1-deoxi-D-threo-2-pentulose, tirosina e cisteína (Julliard \& Douce, 1991). De acordo com esta observação, as proteínas THI1-1 e THI1-2 de milho, AgTHI1 de Alnus e THI1 de Arabidopsis são sintetizadas com um peptídeo de trânsito cloroplástico. Interessantemente, os genes thi1 de $A$. thaliana e thi1-1 de milho foram capazes de complementar cepas de levedura deficientes na biossíntese de tiamina (Machado et al., 1996; Belanger et al., 1995). Entretanto, em leveduras este processo ocorre em mitocôndrias. Isto sugere que o peptídeo de trânsito destas proteínas é capaz de direcioná-las para mitocôndrias.

Embora o gene thi1 de $A$. thaliana codifique uma proteína envolvida na biossíntese de tiamina, mais especificamente na formação de um de seus precursores: o tiazol, que ocorre em cloroplastos, o cDNA foi originalmente clonado pela sua capacidade de complementar bactérias deficientes em reparo de DNA. Além disso, este cDNA apresentou uma homologia com genes relacionados ao estresse em Fusarium (sti35) (Choi et al., 1990).

Esta propriedade de proteção ao material genético de E. coli não está relacionada com a síntese de tiamina per se, uma vez que não foram encontradas diferenças quando os experimentos foram realizados na presença ou ausência de tiamina no meio de cultura. Portanto, THl1 parece ser uma proteína bifuncional que atua tanto no reparo de DNA quanto na biossíntese de tiamina (Machado et al., 1996).

Machado et al. (1997) estudaram o comportamento do homólogo de thi1 em leveduras (thi4) a fim de verificar a possibilidade desta enzima também apresentar um papel adicional em reparo de DNA ou tolerância a danos ao material genético. Os resultados indicaram que THI4 desempenha um papel importante na diminuição dos efeitos deletérios provocados por danos ao DNA mitocondrial, reduzindo a freqüência de mutantes respiratórios em 
leveduras. Provavelmente, thi1 desempenha uma função similar de proteção ao DNA organelar em plantas.

A bifuncionalidade da proteína THI1 pode estar relacionada a uma compartimentalização diferencial da proteína dentro da célula. Baseado em observações experimentais realizadas no Brasil e no exterior, acredita-se que a proteína THI1 possa ser direcionada simultaneamente às mitocôndrias e cloroplastos. Trata-se, portanto, de um fenômeno bastante raro na natureza. 


\section{MATERIAL E MÉTODOS}

\subsection{Localização subcelular da proteína THI1 de Arabidopsis thaliana}

\subsubsection{Construções gênicas}

Procedimentos padrões foram utilizados na realização das construções gênicas (Sambrook et al., 1989).

As construções contendo diferentes comprimentos da seqüência de direcionamento de thi1 fusionados ao gene uid $A$, que codifica para a $\beta$ glucuronidase (GUS), foram realizadas da seguinte forma. O cDNA contendo a seqüência completa de thi1 foi clonado em KS(-)BlueScript (Stratagene) (Machado et al., 1996). Dois fragmentos de diferentes tamanhos foram obtidos por PCR. O primeiro deles, denominado THI4 corresponde ao peptídeo de trânsito completo de THI1 seguido por 4 aminoácidos da proteína madura, o segundo (THI27) corresponde ao peptídeo de trânsito completo seguido de 27 aminoácidos da proteína THI1 madura, incluindo a região onde encontram-se as metioninas conservadas (Chabregas et al., 2001).

A necessidade de se adequar os fragmentos de DNA (o gene thi1 e o gene uidA) a fim de facilitar a clonagem e garantir a fusão traducional das construções, exigiu modificações nas extremidades (via PCR).

Foram sintetizados oligonucleotídeos providos com o sítio para a enzima Hindll (em itálico) nas extremidades. Os oligonucleotídeos utilizados para amplificação do fragmento THI4 foram os seguintes: 
THI : 5'- CCCAAGCTTCAAAATGGCTGC -3'

THI 4 : 5'- CCCAAGCTTGGGTCGAACGTGAAAGC -3'

Para amplificação do fragmento THI27, foram utilizados os oligonucleotídeos:

THI: idem à anterior

THI 27 : 5'-CCCAAGCTTCCAGCATAAGTGATC-3'

Todas as reações de PCR utilizadas durante o trabalho foram baseadas na seguinte:

DNA

Tampão (10X concentrado)

$\mathrm{THI}$

THI-4/THI27

dNTP

Taq DNA polimerase
$0,1 \mu \mathrm{g}$

$5,0 \mu \mathrm{l}$

30,0 pmoles

30,0 pmoles

$0,03 \mathrm{mM}$

1,5 unidades

O volume da reação foi completado a $50 \mu \mathrm{l}$ com água.

- desnaturação: $94^{\circ} \mathrm{C}$ por 30 segundos

- anelamento: $55^{\circ} \mathrm{C}$ por 30 segundos

- extensão: $72^{\circ} \mathrm{C}$ por 30 segundos

25 ciclos

A seqüência codificando para a proteína GUS, foi clonada nos sítios Hindll e EcoRI do plasmídeo SK(+)BlueScript (Stratagene), resultando no vetor denominado SK(+)GUS (Silva-Filho et al., 1996). Depois da amplificação, os fragmentos foram digeridos com Hindll e subclonados no mesmo sítio no vetor, resultando nas fusões THI4-GUS e THI27-GUS. 
Para a clonagem destas fusões em um vetor de transformação de plantas, os plasmídeos SK(+)THI4-GUS e SK(+)THI27-GUS foram parcialmente digeridos com Hindll, seguida por uma digestão total por EcoRI, liberando os fragmentos THI4-GUS e THI27-GUS, respectivamente. Estes fragmentos foram inseridos dentro dos sítios correspondentes no vetor binário utilizado para transformação de plantas Bin2-35ScatE9' (Chaumont et al., 1994), produzindo os vetores de transformação Bin2-35S-THI4-GUS-E9' e Bin2-35S-THI27-GUS-E9'.

\subsubsection{Cepas bacterianas}

Durante as etapas de clonagem, foram utilizadas as cepas bacterianas Escherichia coli JM109 (Yanisch-Perron et al., 1985) e Agrobacterium tumefaciens LBA4404 (Hoekema et al., 1983).

\subsubsection{Análise dos transformantes ("Screening" por PCR)}

A análise das colônias transformantes foi realizada via PCR: as colônias foram repicadas em uma placa "Master", antes do início da amplificação.

Os clones referentes à transformação com as construções SK(+)THI4-GUS e SK(+)THI27-GUS foram analisados diretamente, utilizando numa primeira etapa, os oligonucleotídeos:

THI : descrito acima

GUS 2 : 5'- ACGCTGCGATGGATTCCGGC -3' (que se anela ao gene uidA).

A fim de verificar o número de fragmentos THI4 e THI27 ligados ao vetor, uma segunda análise foi realizada somente com as colônias cujo resultado foi positivo no PCR anterior: 
UP : 5'- TGACCGGCAGCAAAATG -3' (anela-se ao vetor SK(+)gus)

GUS 2 : descrito acima.

Todas as reações de PCR utilizadas nesta etapa foram semelhantes à descrita anteriormente, diferindo somente para a temperatura de anelamento dos oligonucleotídeos utilizados.

\subsubsection{Seqüenciamento dos clones SK(+)THI4-GUS e SK(+)THI27-GUS}

Alguns clones positivos foram enviados para seqüenciamento automático (seqüenciador de DNA ABI PRISM 377) no Laboratório de Entomologia, Fitopatologia e Zoologia Agrícola da ESALQ, sob a coordenação do Prof. Dr. Luiz Eduardo Aranha Camargo.

A reação de seqüenciamento, foi realizada usando-se os procedimentos descritos no manual do kit "ABI PRISM ${ }^{\circledR}$ Big Dye $^{T M}$ TERMINATOR CYCLE SEQUENCING READY REACTION KITS". Seguindo este protocolo, em tubos de 0,2 $\mathrm{mL}$ foram adicionados $2 \mu \mathrm{L}$ de "mix Big Dye" (que contém dNTP, terminadores ddNTPs associados à substâncias fluorescentes e AmpliTaq DNA polimerase, FS), 3 picomoles de primer (no caso, UP descrito anteriormente), 10,5 $\mu \mathrm{L}$ de água estéril, $6 \mu \mathrm{L}$ de tampão Tris$\mathrm{HCl}$ pH 9,0 contendo cloreto de magnésio e 0,5 $\mu \mathrm{L}$ de DNA plasmidial (200-500 ng). A seguinte reação de PCR foi utilizada:

- $\quad 96^{\circ} \mathrm{C}$ por 2 minutos

- $\quad 96^{\circ} \mathrm{C}$ por 20 segundos

- $\quad 50^{\circ} \mathrm{C}$ por 10 segundos 25 ciclos

- $60^{\circ} \mathrm{C}$ por 4 minutos

- $\quad 72^{\circ} \mathrm{C}$ por 7 minutos 
Após a reação de amplificação, as amostras foram transferidas para microtubos de 0,65 mL e adicionou-se uma solução contendo $20 \mu \mathrm{L}$ de água estéril $+60 \mu \mathrm{L}$ de isopropanol. Essa mistura foi deixada à temperatura ambiente por 15 minutos e centrifugada em uma microcentrífuga de bancada (velocidade máxima) por 20 minutos. O sobrenadante foi cuidadosamente descartado e o precipitado lavado com $250 \mu \mathrm{L}$ de etanol $70 \%$ (preparado na hora). Centrifugou-se por mais 15 minutos sob as mesmas condições anteriores e o sobrenadante foi novamente descartado. Os tubos, com as tampas abertas, foram colocados por 1 minuto em termociclador, previamente aquecido à $90^{\circ} \mathrm{C}$ para a completa evaporação da água das amostras.

No laboratório onde foi realizado o seqüenciamento, as amostras foram ressuspendidas em $4 \mu \mathrm{L}$ de tampão contendo 5 partes de formamida e 1 parte de "loading buffer" (0,25\% azul de bromofenol, 0,25\% xileno cianol e $40 \%$ sacarose), o DNA foi desnaturado à $98{ }^{\circ} \mathrm{C}$ por 2 minutos e $1 \mu \mathrm{L}$ de cada amostra foi aplicado no gel por Daniela Truffi.

As colônias com a seqüência desejada foram repicadas e estocadas em glicerol a $-80^{\circ} \mathrm{C}$.

\subsubsection{Meios de cultura}

Para crescimento de E. coli e A. tumefaciens foi utilizado o meio de cultura Luria-Bertani (LB), composto de $1 \%(\mathrm{p} / \mathrm{v})$ de bacto-triptona, $0,5 \%$ $(\mathrm{p} / \mathrm{v})$ de extrato de levedo, $1 \%(\mathrm{p} / \mathrm{v})$ de $\mathrm{NaCl}, \mathrm{pH} 7,5$, acrescido de $0,01 \%(\mathrm{p} / \mathrm{v})$ de canamicina (para E. coli) e $0,01 \%(\mathrm{p} / \mathrm{v})$ de rifampicina (para A. tumefaciens). Quando necessário, 0,8\% de bácto-agar foi adicionado ao meio.

Para a transformação e crescimento das plantas, o meio MS de Murashige e Skoog (1962) foi adquirido da SIGMA e suplementado com 0,8\% $(\mathrm{p} / \mathrm{v})$ de ágar. Foram também utilizados os meios: 
- MSACKC: que consiste no meio básico MS, acrescido de $2 \times 10^{-5} \%(\mathrm{p} / \mathrm{v})$ de ácido indol acético, $2 \times 10^{-5} \%(\mathrm{p} / \mathrm{v})$ de $6-\mathrm{BAP}, 0,04 \%(\mathrm{p} / \mathrm{v})$ de carbenicilina, $0,01 \%(p / v)$ de canamicina e $0,04 \%(p / v)$ de cefotaxime;

- MSAKC: idêntico ao meio descrito acima, sem a adição de 6-BAP e carbenicilina.

\subsubsection{Transformação de plantas}

Discos foliares de aproximadamente $1 \mathrm{~cm}^{2}$ foram retirados de plantas de Nicotiana tabacum, variedade SRI, crescidas in vitro, e colocados em meio MS (Murashige \& Skoog, 1962). Os discos foram perfurados com uma agulha contendo $A$. tumefaciens transformada com as construções Bin2-35STHI4-GUS-E9' e Bin2-35S-THI27-GUS-E9'.

Após três dias, foram transferidos para meio MSACKC. A partir de 15 dias após a transferência, surgiram as primeiras plântulas por organogênese direta. O enraizamento foi favorecido pela transferência das plântulas para meio MSAKC.

\subsubsection{Análise das plantas transgênicas}

\subsubsection{Teste GUS histoquímico}

Para análise da expressão do gene uidA, foi realizado um teste histoquímico utilizando o substrato X-Gluc (5-bromo-4-cloro-3-indol $\beta$-Dglucuronide ciclohexilamino) (Jefferson et al., 1987).

Uma amostra foliar foi retirada da planta a ser analisada com a tampa de um microtubo e depositada dentro dele. Tampão de reação composto de $10 \mathrm{mM}$ de $\mathrm{NaH}_{2} \mathrm{PO}_{4}, 100 \mathrm{mM}$ de $\mathrm{Na}_{2}$ EDTA, 0,5 mM de $\mathrm{K}_{4} \mathrm{Fe}(\mathrm{CN})_{6} .3 \mathrm{H}_{2} \mathrm{O}$, $0,1 \%$ de TRITON X-100 e $0,1 \mathrm{mM}$ de X-Gluc foi adicionado em quantidade 
suficiente para cobrir a amostra. Esta preparação foi incubada a $37^{\circ} \mathrm{C}$ por $1 \mathrm{a}$ 24 horas (a reação deve ser monitorada).

Após a reação, o material é fixado em uma solução de ácido acético e etanol na proporção de 3:1.

\subsubsection{Extração de DNA de plantas}

O DNA genômico das plantas com reação histoquímica positiva foi extraído segundo metodologia descrita por Edwards e colaboradores (1991).

\subsubsection{Reações de PCR}

As reações de PCR utilizadas na análise das plantas transformadas foram realizadas com os primers THI e GUS2, descritos anteriormente.

\subsubsection{Fracionamento subcelular}

Para isolamento de cloroplastos e mitocôndrias, cerca de 10 gramas de folhas foram lavados e colocados em liqüidificador juntamente com $100 \mathrm{~mL}$ de tampão de homogeneização [330 mM de sacarose, $50 \mathrm{mM}$ de Tris$\mathrm{Cl} \mathrm{pH} \mathrm{8,0,0,2 \%} \mathrm{(p/v)} \mathrm{de} \mathrm{BSA,} \mathrm{0,4 \%} \mathrm{(v/v)} \mathrm{de} \beta$-mercaptoetanol e 0,2\% (p/v) de polivinilpirrolidona (PVP)] e 3 a 5 pulsos foram efetuados para rompimento das células. Todos os passos subsequentes foram realizados no gelo.

O homogeneizado foi filtrado utilizando-se duas camadas de papel Miracloth $^{\circledR}$ e duas frações de $1 \mathrm{~mL}$ foram recolhidas em tubos de microcentrífuga. Um dos tubos foi mantido no gelo [homogeneizado $(H)$ ] e o outro centrifugado por 5 minutos em microcentrífuga de bancada a rotação máxima. Deste último, separaram-se as frações referentes ao precipitado $(P)$ e o sobrenadante citosólico (S) em outros tubos. O restante do homogeneizado 
filtrado foi centrifugado ( 3 minutos, $3.500 \mathrm{rpm}$, rotor Sorvall ST-H50). O sobrenadante foi recuperado em garrafas plásticas de $250 \mathrm{~mL}$ e centrifugado para separação mitocondrial (descrito a seguir) e o precipitado ressuspendido em $2 \mathrm{~mL}$ de tampão de suspensão [0,4 $\mathrm{M}$ de manitol, $10 \mathrm{mM}$ de $\mathrm{KH}_{2} \mathrm{PO}_{4} \mathrm{pH}$ 7,2 $(\mathrm{KOH}), 0,2 \%(\mathrm{p} / \mathrm{v}) \mathrm{BSA}$ ]. Essa amostra foi depositada cuidadosamente sobre um gradiente de Percoll contido num tubo Corex [4 $\mathrm{mL}$ de Percoll $80 \%(\mathrm{v} / \mathrm{v})$, $250 \mathrm{mM}$ de sacarose e 4,8 $\mathrm{mL}$ de Percoll 40\% (v/v), $250 \mathrm{mM}$ de sacarose]. $\mathrm{O}$ tubo Corex foi centrifugado por 10 minutos, $10.000 \mathrm{rpm}$, rotor ST-H50 da Sorvall. Após a centrifugação, a fração enriquecida de cloroplastos intactos foi coletada na interface das camadas de Percoll e diluída em tampão de suspensão sem BSA. Centrifugou-se por 3 minutos, $3.500 \mathrm{rpm}$ no rotor ST-H50. O sobrenadante foi descartado e o precipitado, correspondente à fração enriquecida de cloroplastos, ressuspendido em $1 \mathrm{~mL}$ de tampão de suspensão sem BSA. Esta etapa foi repetida para a eliminação do Percoll. O precipitado final foi ressuspendido em $0,15 \mathrm{~mL}$ de tampão de suspensão sem BSA.

Mitocôndrias foram isoladas como segue: o sobrenadante da primeira centrifugação, recuperado em garrafas de $250 \mathrm{~mL}$, foi centrifugado por 15 minutos, $12.500 \mathrm{rpm}$, rotor Sorvall SL-250T. O precipitado foi ressuspendido em $2 \mathrm{~mL}$ de tampão de suspensão e depositado cuidadosamente sobre um gradiente de Percoll [ $6 \mathrm{~mL}$ de Percoll 45\% (v/v), $250 \mathrm{mM}$ de sacarose e $9 \mathrm{~mL}$ de Percoll 21\% (v/v), $250 \mathrm{mM}$ de sacarose], sendo posteriormente centrifugado por 30 minutos, $20.000 \mathrm{rpm}$, rotor SW 30 Beckman. Uma fração enriquecida com mitocôndrias intactas foi recuperada da interface das camadas de Percoll e diluída em tampão de suspensão sem BSA. Centrifugou-se por 5 minutos, em rotação máxima em microcentrífuga. $O$ sobrenadante foi descartado e 0 precipitado ressuspendido em $1 \mathrm{~mL}$ de tampão de suspensão sem BSA. Essa etapa foi repetida para a eliminação do Percoll. O precipitado final foi ressuspendido em $0,1 \mathrm{~mL}$ de tampão de suspensão sem BSA (Bartlett et al., 1982; Pilon et al., 1992; Silva-Filho et al., 1997). 


\subsubsection{Quantificação de proteínas das frações subcelulares}

A dosagem de proteínas nas frações subcelulares obtidas foi realizada segundo método descrito por Lowry (1951).

\subsubsection{Eletroforese e imunodetecção}

Proteínas das frações subcelulares foram solubilizadas em $80 \mathrm{mM}$ Tris, 2\% (p/v) SDS, 10\% (p/v) Glicerol, 0,005\% (p/v) Azul de Bromofenol e 1\% Dithiothreitol, pH 6,8 ( $\mathrm{HCl})$ por 15 minutos à $55^{\circ} \mathrm{C}$ e, então, separadas por SDS em eletroforese em gel de poliacrilamida (Laemmli, 1970), a uma corrente constante de $100 \mathrm{~V} / g$ el. As proteínas foram transferidas para uma membrana de nitrocelulose 0,45 $\mu \mathrm{m}$ da BioRad (Towbin et al., 1979).

Após a transferência, a membrana de nitrocelulose foi lavada, sob agitação, com aproximadamente $50 \mathrm{~mL}$ de tampão fosfato salino (PBS) composto de de $137 \mathrm{mM}$ de $\mathrm{NaCl}, 2,7 \mathrm{mM}$ de $\mathrm{KCl}, 30,2 \mathrm{mM}$ de $\mathrm{NaH}_{2} \mathrm{PO}_{4}, 1,8$ $\mathrm{mM}$ de $\mathrm{KH}_{2} \mathrm{PO}_{4}, \mathrm{pH} 7,4$ durante 5 minutos. Depois, ela foi saturada com uma solução contendo $5 \%$ de leite em pó desnatado e $0,2 \%(\mathrm{v} / \mathrm{v})$ de Tween 20. A membrana foi lavada 3 vezes por 10 minutos com tampão Tris salino (TBS) + 0,1\% (v/v) de Tween 20 (TBS-T), e incubada por 1 hora e 30 minutos com anticorpos. Os anticorpos utilizados foram:

- ANTI-LDH (marcador mitocondrial), gentilmente cedido pelo Prof. Marc Boutry da Université Catholique de Louvain - Bélgica, na diluição de 1:2.500 (Silva-Filho et al., 1996);

- ANTI-RUBISCO (marcador cloroplástico), gentilmente cedido pelo Prof. Carlos Alberto Labate, Departamento de Genética - ESALQ/USP, na diluição de 1:8.000.

Após a incubação com o respectivo anticorpo primário, a membrana foi novamente lavada 3 vezes por 10 minutos em TBS-T e incubada 1 hora com o anticorpo secundário. Os anticorpos secundários utilizados foram: 
- ANTI-RABBIT Ig (ECL - Wester Blotting Analysis System - Amersham LIFE SCIENCE) na diluição 1:2.000;

- ANTI-RABBIT IgG conjugado à fosfatase alcalina (Promega) nas diluições de 1:5000 e 1:10.000.

Novamente, a membrana foi lavada 3 vezes 10 minutos com TBST e a detecção foi realizada segundo orientação do fabricante do anticorpo secundário.

\subsubsection{7- Quantificação da atividade GUS}

A atividade GUS nas frações subcelulares foi detectada a partir de material acondicionado a $-80^{\circ} \mathrm{C}$. Segundo protocolo adaptado de Jefferson e colaboradores (1987), 2,5 a $5 \mu \mathrm{g}$ de proteína dos extratos foram colocadas em tubos de microcentrífuga, o volume completado com $180 \mu \mathrm{l}$ de tampão fosfato $50 \mathrm{mM} \mathrm{pH} \mathrm{7,0} \mathrm{e} \mathrm{incubados} \mathrm{por} 10$ minutos a $37^{\circ} \mathrm{C}$. A reação iniciou-se com a adição de $20 \mu \mathrm{l}$ de solução $10 \mathrm{mM}$ MUG (4-Metilumbeliferril $\beta$-D-glucuronide trietilamina). Nos tempos 0,5 e 10 minutos uma amostra de $60 \mu \mathrm{l}$ foi transferida para uma cuveta contendo $0,9 \mathrm{~mL}$ de $0,2 \mathrm{M} \mathrm{Na}_{2} \mathrm{CO}_{3}$ à temperatura ambiente $\mathrm{e}$ a concentração de $4 \mathrm{MU}$ (7-hidroxi-4-metilcoumarine), produto da reação do substrato MUG com a enzima $\beta$-glucuronidase (GUS), foi determinada em fluorômetro (excitação a 365 nm e emissão a 455 nm) (Jefferson et al., 1987).

\subsubsection{8- Gel de atividade GUS}

Eletroforese das proteínas das frações subcelulares (homogeneizado, cloroplastos e mitocôndrias) foi realizada conforme descrito anteriormente, sem adição de SDS aos tampões (condições não desnaturantes). 
Após a eletroforese, a detecção da atividade GUS foi realizada incubando-se o gel em uma solução de MUG (0,5 mM em tampão fosfato) a $37^{\circ} \mathrm{C}$ por 10 minutos, segundo procedimentos adaptados de Lee e Schöffl (1997).

\subsection{4- Preparação de anticorpos policlonais Anti-THl1}

O desenvolvimento de todo o trabalho para a obtenção dos anticorpos Anti-THI1 foi realizado no laboratório do Prof. Dr. Flávio César Almeida Tavares, Departamento de Genética, ESALQ, em colaboração com a Dra. Keila Maria Roncato Duarte.

A proteína THI1 foi expressada e purificada em E. coli e gentilmente cedida por Douglas D. Luche (Instituto de Ciências Biomédicas 2/USP) e Paulo Henrique Conaggin Godoi (USP/São Carlos).

\subsubsection{Imunização dos animais}

Os procedimentos foram utilizados conforme descrito por Duarte (1996) com pequenas alterações.

4 fêmeas de camundongo pertencentes à linhagem BALB/c, com características favoráveis para a produção de anticorpos, foram utilizadas. As fêmeas foram marcadas com ácido pírico e inoculadas a cada 15 dias com a proteína THI1.

$\mathrm{Na}$ primeira inoculação, foram utilizados $10 \mu \mathrm{g}$ da proteína por camundongo, misturados a $400 \mu \mathrm{l}$ de Adjuvante Completo de Freud (Sigma) e $500 \mu \mathrm{l}$ de PBS. A inoculação é feita por injeção subcutânea de aproximadamente $0,1 \mathrm{~mL}$ por camundongo em 2 sítios diferentes (duas patas traseiras). A segunda imunização foi realizada usando Adjuvante Incompleto de Freund (Sigma) e PBS, além da mesma concentração da proteína. A partir da 
terceira imunização utilizou-se apenas PBS e a proteína (10 $\mu \mathrm{g}$ por camundongo).

\subsubsection{Titulação do soros por "Enzyme Linked Immunosorbent Assay" (ELISA)}

Os soros foram coletados, antes de cada imunização, do plexo ocular dos camundongos, previamente anestesiados em éter, com o auxílio de uma pipeta Pasteur.

As alíquotas de sangue coletadas (cerca de 0,1 $\mathrm{mL}$ ) foram mantidas a $37^{\circ} \mathrm{C}$ por 1 hora, centrifugadas a $200 \times \mathrm{g}$ por 2 minutos para a separação do soro. O soro é retirado e acondicionado no freezer.

A titulação do soro dos animais foi feita através de teste ELISA indireto. Para o teste, foram usadas 3 diluições da proteína THI1: 0,5 $\mu \mathrm{g} \cdot \mathrm{mL}^{-1}$, $1,0 \mu \mathrm{g} \cdot \mathrm{mL}^{-1}$ e $2,0 \mu \mathrm{g} \cdot \mathrm{mL}^{-1}$. Os soros foram diluídos na proporção de 1:200 em PBS.

Placas de polivinil de 96 orifícios foram sensibilizadas com $50 \mu \mathrm{l}$ antígeno (proteína THI1 nas concentrações citadas acima) e incubadas por 1 hora a $37{ }^{\circ} \mathrm{C}$. Em seguida foram aplicados $50 \mu$ de tampão de bloqueio, composto de PBS e 1\% de BSA (soro de albumina bovina), que constitui uma proteína inerte encarregada de preencher os espaços deixados pela proteína THI1. Seguiu-se incubação por 1 hora a $37^{\circ} \mathrm{C}$. Cinqüenta $\mu$ da diluição dos soros a serem testados foram aplicados em duplicata e incubados por 1 hora a $37^{\circ} \mathrm{C}$. Os orifícios foram, então lavados por 3 vezes com uma solução de PBST-G constituída de PBS, 0,05\% de Tween 20 e 0,25\% de gelatina.

A seguir, a placa foi incubada por mais 1 hora a $37^{\circ} \mathrm{C}$ com conjugado Anti-Mouse IgG (Pierce) marcado com fosfatase alcalina 1.000 vezes diluído. Foram feitas mais 3 lavagens com Tampão PBS-T-G e foi aplicado o substrato da fosfatase alcalina (PNPP- p-Nitrofenil Fosfato) juntamente com o 
tampão de revelação constituído de $10 \mathrm{mM}$ de dietanolamina e $0,5 \mathrm{mM}$ de $\mathrm{MgCl}_{2}$. A placa foi incubada por 20 minutos no escuro para revelação e procedeu-se a leitura em leitor de ELISA a $405 \mathrm{~nm}$.

\subsubsection{Purificação e quantificação dos anticorpos Anti-THl1}

O soro total foi retirado dos camundongos e a purificação do anticorpo policlonal ANTI-THI1 foi realizada em coluna de Sepharose Proteína A, segundo procedimento sugerido por Duarte (1996).

A coluna foi lavada com Tris- $\mathrm{NaCl} \mathrm{pH} 8,2$ por 1 hora. $\mathrm{O}$ soro foi preparado na proporção de $1,5 \mathrm{~mL}$ de soro : $4 \mathrm{~mL}$ de Tris- $\mathrm{NaCl} \mathrm{pH} 8,2$ e filtrado na coluna em sistema fechado por 2 horas. Depois, a coluna é, novamente lavada com Tris- $\mathrm{NaCl}$ pH 8,2 por 1 hora. $\mathrm{O}$ anticorpo é recuperado em tampão glicina- $\mathrm{NaCl}$ pH 3,0 (50 mM glicina, $150 \mathrm{mM} \mathrm{NaCl}$ ) e recolhido em tubos contendo $50 \mu \mathrm{l}$ de Tris- $\mathrm{HCl} 1 \mathrm{M} \mathrm{pH}$ 9,0. Os anticorpos purificados foram quantificados em espectrofotômetro à $280 \mathrm{~nm}$.

\subsubsection{Teste dos anticorpos Anti-THI1 em extratos de plantas}

\subsection{Extração de proteínas foliares de N. tabacum e A. thaliana}

Para a extração de proteínas totais, cerca de $1 \mathrm{~g}$ de folha fresca foi macerado em nitrogênio líquido e misturado a $2,5 \mathrm{~mL}$ de tampão de extração composto de $100 \mathrm{mM}$ de Tris-Cl pH 7,6 e 0,1\% (p/v) de ácido ascórbico. Ao descongelar, o extrato foi recolhido em microtubos e centrifugado por 2 minutos a máxima rotação em microcentrífuga. $O$ sobrenadante contendo o extrato protéico foi recolhido em novos tubos e armazenado a $-80{ }^{\circ} \mathrm{C}$ para análises posteriores. 


\subsection{Quantificação de proteínas dos extratos protéicos foliares}

O teor de proteína no extrato foi determinado pelo método descrito por Bradford (1976), modificado para ensaio em placas de ELISA, onde $200 \mu \mathrm{L}$ de reagente de Bradford (50 mg de Coomassie Briliant Blue G-250 dissolvidas em $25 \mathrm{~mL}$ de etanol, aos quais adiciona-se $50 \mathrm{~mL}$ de ácido fosfórico, completando-se o volume com água para $500 \mathrm{ml}$ ) foi adicionado a $2 \mu \mathrm{L}$ de extrato para reagir por 5 minutos. A concentração protéica das amostras foi determinada via espectrofotômetro, na densidade óptica a $595 \mathrm{~nm}$, tomando-se como base a regressão linear de uma curva padrão construída com soro de albumina bovina (BSA), em concentrações de proteína variando de 2,0 a 12,0 g. $\mathrm{L}^{-1}$.

\subsection{Teste ELISA}

Os anticorpos Anti-THI1 foram testados em placa ELISA usando a proteína THI1 pura $(0,1 \mu \mathrm{g})$ e extratos foliares de $N$. tabacum $(75 \mu \mathrm{g}$ de proteína total). O anticorpo Anti-THI1 foi utilizado nas concentrações 50 e $100 \mu \mathrm{g} \cdot \mathrm{mL}^{-1}$. Os procedimentos do teste ELISA realizado foram semelhantes aos descritos anteriormente.

\subsection{Eletroforese e imunodetecção}

Os anticorpos produzidos também foram testados em experimentos de "western blotting", semelhantes aos descritos anteriormente. Os anticorpos utilizados foram os seguintes:

- ANTI-THI1, usado nas diluições de 1:500 e 1:1.000;

- ANTI-MOUSE IgG conjugado à fosfatase alcalina (Promega) na diluição de 1:2.000. 
Os testes foram realizados com a proteína THI1 pura nas concentrações de 2, 1, 0,5 e 0,2 $\mu \mathrm{g}$ e com extratos foliares de $A$. thaliana nas concentrações de 120, 100, 50 e $20 \mu \mathrm{g}$ de proteína total.

\subsubsection{Imunolocalização da proteína THI1 em A. thaliana}

Os experimentos de imunolocalização da proteínas THI1 em $A$. thaliana foram realizados pelo Prof. Dr. Alberto Ribeiro e por Waldir Caldeira, do Núcleo de Microscopia Eletrônica do Instituto de Biociências da USP.

Plantas jovens de $A$. thaliana de aproximadamente um mês, cortadas em seções de $0,5 \mathrm{~mm}$, foram fixadas em $4 \%$ de paraformaldeído com

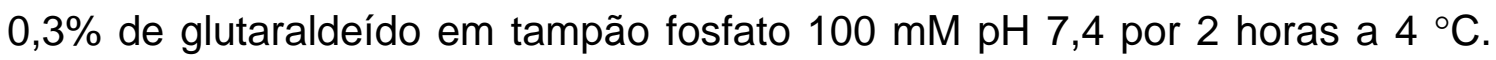
Depois de lavado com tampão fosfato, o material foi desidratado em soluções de etanol à temperatura ambiente, e embebido em resina acrílica L.R.White (Electron Microscopy Sciences, Ft. Washington, USA). Seções ultra-finas foram cortadas em ultramicrótomo LKBONova e coletados em grades coletores de níquel, malha 200. As grades foram flutuadas em gotas de TBS a $\mathrm{pH} \mathrm{7,2}$ contendo $1 \%$ de BSA (Sigma, USA) por 1 minuto e colocados em NGS (Amersham, UK), diluição 1:30, por 30 minutos. As seções foram incubadas durante a noite em anticorpo primário (Anti-THI1) diluído 1 vez em TBS a pH 7,2 , contendo $1 \%$ de BSA a $4{ }^{\circ} \mathrm{C}$.

Como um controle, secções foram incubadas com soro não imune usando as mesmas condições. Depois de lavadas 4 vezes por 5 minutos em TBS $\mathrm{pH} 7,2$ com $0,2 \%$ de $B S A, 0,05 \%$ de $\mathrm{NaN}_{3}$ e $0,1 \%$ de Tween 20 , as amostras foram colocadas em TBS pH 8,2 com 1\% de BSA e 0,05\% de $\mathrm{NaN}_{3}$ por 1 hora à temperatura ambiente, e incubadas com Anti-mouse lgG acoplado com partículas de ouro de $15 \mathrm{~nm}$ (Amersham, UK) diluído 1:15 em TBS pH 8,2 mais $1 \%$ de $\mathrm{BSA}$ e $0,05 \%$ de $\mathrm{NaN}_{3}$, por 1 hora a temperatura ambiente.

As grades foram, então, lavadas $4 \times 5$ minutos em TBS a pH 7,2 contendo $0,2 \%$ de $\mathrm{BSA}, 0.05 \%$ de $\mathrm{NaN}_{3}$ e $0,1 \%$ de Tween 20 , seguido pela 
mesma solução sem BSA ( $2 \times 5$ minutos). Depois da fixação em 2,5\% de glutaraldeído em $100 \mathrm{mM}$ de tampão sódio cacodilato $\mathrm{pH} 7,4$ por 10 minutos a temperatura ambiente, as amostras foram finalmente lavadas em água bidestilada, marcada com uranil acetato e citrato de chumbo, e examinadas em microscópio eletrônico Zeiss EM 900.

\subsubsection{Análise de proteção à nuclease $\mathrm{S1}$}

Os experimentos de mapeamento do início do transcrito do gene thi1 foram realizados por Leonardo P. Farias (Laboratório da Profa Marie-Anne van Sluys - Instituto de Biociências/USP).

RNA foi extraído de plantas de $A$. thaliana crescidas in vitro usando TRIzol ${ }^{\circledR}$ (Life Technologies). A extremidade 5 ' foi mapeada por dois métodos: (a) sistema 5'-RACE ${ }^{\circledR}$ (Life Technologies). A primeira fita foi sintetizada a partir do RNA total usando o oligonucleotídeo 5'CCAGCAGATCCAGCACC -3' complementar à seqüência codante entre as posições +274 a +284 e transcriptase reversa. Depois da síntese da primeira fita de cDNA, o mRNA usado como molde original foi removido por tratamento com RNAse. Uma cauda homopolimérica foi adicionada à extremidade 3 ' do cDNA. Uma reação de PCR foi realizada utilizando-se o oligonucleotídeo descrito acima e um outro ancorador. Depois da amplificação, os produtos $5^{\prime}$ RACE foram clonados em vetor pGEM (Promega). Os clones foram analisados por seqüenciamento. (b) análise de proteção à nuclease S1 (Sharp et al., 1980). $\mathrm{O}$ oligonucleotídeo descrito acima foi marcado com $\mathrm{P}^{32}$ com polinucleotídeo quinase. A sonda foi gerada pelo anelamento do oligonucleotídeo ao DNA desnaturado contendo a região que codifica o promotor de thi1. $O$ oligonucleotídeo foi estendido usando DNA polimerase I (fragmento Kleenow) e digerido com Spel. A mistura de reação foi desnaturada e a sonda de DNA fita simples (402 pb) foi purificada em gel de agarose alcalino. $50 \mu \mathrm{g}$ de RNA total foi hibridizado com a sonda de DNA fita simples seguido pela digestão com 
nuclease S1. O fragmento protegido foi analisado em gel de poliacrilamida desnaturante a $6 \%$.

3.2 Caracterização dos mecanismos de regulação da expressão gênica de thi1 e suas implicações na localização subcelular da proteína

\subsubsection{Experimentos de transcrição e tradução in vitro}

\subsubsection{Construções gênicas}

A fim de realizar as construções gênicas que serão utilizadas nesta etapa do trabalho, foram amplificados alguns fragmentos a partir do cDNA de thi1. Em todos os casos, optou-se por trabalhar com 64 aminoácidos da proteína, fusionados ao gene repórter uidA (GUS). Mutações sítio-dirigidas foram introduzidas pontualmente por PCR. Todos os procedimentos utilizados para a clonagem foram semelhantes aos descritos anteriormente.

Os fragmentos amplificados a partir do cDNA de thi1 e os oligonucleotídeos utilizados, foram os seguintes:

- THI64:

THI2: 5'- CCCGGTACCCAAAATGGCTGC -3'

THI64: 5'- CCCAAGCTTCCAGGACTAACAGATTG -3'

- THI64A:

THI2A: 5'- CCCGGTACCCAAAATCGCTGC -3'

THI64: descrito anteriormente 
- THI64ه':

Para esta construção, foram amplificados dois fragmentos. $O$ primeiro deles contendo os 212 pb iniciais. O outro, contendo os próximos 155 pb, com a mutação desejada.

thia $=$ fragmento de $212 \mathrm{pb}$

THI2: descrito anteriormente THIcont1': 5'- CCCCTCGAGACGATCGATTCCTTG -3'

thib $\Delta$ = fragmento de $155 \mathrm{pb}$

THI2s': 5'- CCCCTCGAGGTCACGTGAGATCACGAG -3'

THI64: descrito anteriormente

- THI641 $\Delta$ :

THIcont1: 5'- CCCGGTACCCCAAATGCCTGC -3'

THI64: descrito anteriormente

- THI642A:

Para esta construção também foram necessárias 2 amplificações, com oligonucleotídeos semelhantes aos utilizados em THI64A'.

thia $=$ fragmento de $212 \mathrm{pb}$ (descrito anteriormente)

thib = fragmento de $155 \mathrm{pb}$

THlcont2: 5'- CCCCTCGAGGTCACGTACCATGGCGAG -3'

THI64: descrito anteriormente 
- THI6412A-gus:

Duas amplificações foram realizadas, da mesma forma que as anteriores.

thia' = fragmento $212 \mathrm{pb}$

THIcont1: descrito anteriormente

THIcont1': descrito anteriormente

thib = fragmento $155 \mathrm{pb}$ (descrito anteriormente)

A reação de amplificação utilizada foi semelhante à descrita anteriormente, com modificações na temperatura de anelamento, em função do conjunto de oligonucleotídeos utilizado.

Os fragmentos amplificados foram clonados em SK(+)GUS (SilvaFilho et al., 1996), da seguinte maneira:

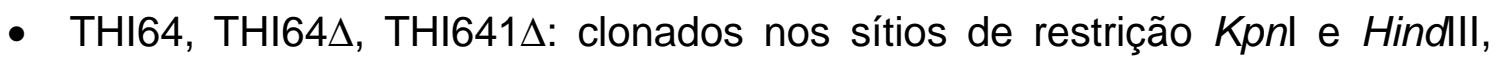
produzindo os vetores SK(+)THI64-GUS, SK(+)THI64A-GUS e SK(+)THI641ه;

- thib e thibs: clonados nos sítios de restrição Xhol e Hindll, produzindo os plasmídeos SK(+)thib-GUS e SK(+)thibs-GUS;

- thia e thia': foram clonados posteriormente, sempre nos sítios de restrição Hindll e Xhol, conforme detalhado a seguir.

Fragmento thia clonado no plasmídeo SK(+)thibs-GUS, produziu o vetor SK(+)THI64 '-GUS. Este mesmo fragmento clonado em SK(+)thib-GUS, produziu o vetor SK(+)THI642 $\Delta$-GUS. O fragmento thia' clonado em SK(+)thib-

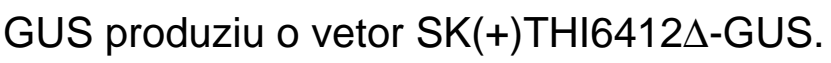

Estes vetores são bastante semelhantes e, em resumo, apresentam as seguintes características: 
- SK(+)THI64-GUS: seqüência original que codifica para o peptídeo de trânsito seguido de 64 primeiros aminoácidos da proteína TH11 madura, fusionada ao gene uidA (GUS);

- $\mathrm{SK}(+)$ THI64A-GUS: idem à anterior com uma mutação do $1^{\circ}$ ATG para ATC;

- SK(+)THI64 $\Delta^{\prime}-G U S:$ mutação do $2^{\circ}$ ATG para ATC;

- SK(+)THI641 - -GUS: mutação (em negrito) no contexto ao redor do 1 ATG (em itálico), de AAAATGGCT para CAAATGCCT, o que torna-o pior para iniciação da tradução, segundo Joshi et al. (1997).

- SK(+)THI642 $\Delta$-GUS: mutação (em negrito) no contexto ao redor do $2^{\circ}$ ATG (em itálico), de GAGATGACG para ACCATGGCG, tornando-o melhor para iniciação da tradução, segundo Joshi et al. (1997);

- SK(+)THI6412 $\Delta$-GUS: mutação no contexto ao redor do $1^{\circ}$ ATG e do $2^{\circ}$ ATG (mesmas mutações das duas construções anteriores);

- SK(+)GUS (Silva-Filho et al., 1996): foi utilizado como controle.

\subsubsection{Transcrição e tradução in vitro}

Os experimentos de transcrição e tradução in vitro foram realizados por Douglas D. Luche (Laboratório do Prof. Carlos Frederico Martins Menck - Instituto de Ciências Biomédicas/USP).

Para a realização do experimento foi utilizado o kit TNT T7 Coupled Transcription/Transduction System (Promega), que realiza a transcrição e a tradução de forma acoplada. Metionina marcada com enxofre radioativo $\left(S^{35}\right)$ (Sigma) foi utilizada.

A eletroforese dos peptídeos obtidos foi realizada em gel de poliacrilamida $10 \%$ desnaturante e a autorradiografia em filme Kodak. Diferentes tempos de exposição foram testados a fim de otimizar a visualização dos resultados 


\subsubsection{Análise da estrutura secundária do mRNA}

A determinação da possível estrutura secundária adquirida pelo mRNA da proteína THI1 foi realizada via internet, utilizando os seguintes endereços:

http://mfold2.wustl.edu/ mfold/rna/for1-2.3.cgi

http://www.ibc.wustl.edu/ zuker/rna/

\subsubsection{Experimentos com "Green Fluorescence Protein" (GFP)}

\subsubsection{Construções gênicas}

As construções gênicas utilizadas nesta abordagem são muito semelhantes às anteriores, contendo a seqüência que codifica para o peptídeo de trânsito da proteína THI1, no entanto seguido de 50 aminoácidos da proteína madura. Algumas mutações semelhantes (original; $1^{\circ}$ ATG mutado para ATC; $2^{\circ}$ ATG mutado para ATC) e outras ainda não descritas foram realizadas.

Os oligonucleotídeos utilizados para amplificação dos fragmentos foram os seguintes:

- THI50: amplificação a partir do plasmídeo KS(-)thi1 (Machado et al., 1996).

THIBgl: 5'- CCCAGATCTCAAAATGGCTGC -3'

THI50Spe: 5'- CCCACTAGTAGGGTTCTTACTGATCTC -3'

- THI50 : amplificação a partir do plasmídeo KS(-)thi1 (Machado et al., 1996).

THIBgI $\Delta:$ 5' - CCCAGATCTCAAAATCGCTGC -3'

THI50Spe: descrito acima 


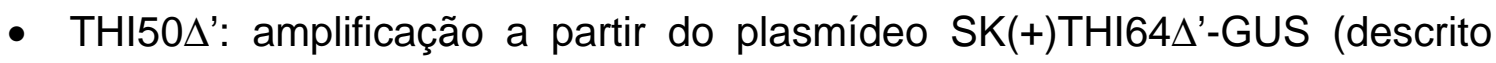
anteriormente)

THIBgl: descrito acima

THI50Spe: descrito acima

- MET2: corresponde à seqüência de direcionamento mitocondrial, iniciando a partir da segunda metionina.

MET2: 5'- CCCAGATCTGAGATGACGAGAAGGTAC -3'

THI50Spe: descrito anteriormente

Os fragmentos thi50, thi50 4 , thi50 $\Delta^{\prime}$ e MET2 amplificados foram digeridos com as enzimas Spel e Bg/ll e clonados nos respectivos sítios no plasmídeo pCAMBIA1302 (Roberts et al., 1997). Os procedimentos de clonagem foram semelhantes aos descritos anteriormente.

Outra mutação realizada foi a troca do aminoácido 43 (serina) por alanina:

- THIS43A:

Para esta construção, foram amplificados dois fragmentos. O primeiro deles contendo os 136 pb iniciais, com a mutação. O outro, contendo os próximos 184 pb.

$\mathrm{S} 43 \mathrm{~A}$ = fragmento de $136 \mathrm{pb}$.

THI2: 5'-CCCGGTACCCAAAATGGCTGC -3'

THIS43A: 5' - CCCGGGCCCGCGAACGGCGAAAGATCG -3'

SER' = fragmento de $184 \mathrm{pb}$.

THISER': 5' - CCCGGGCCCACAACCGCTGGTTACG -3' 
THI50Spe: 5'- CCCACTAGTAGGGTTCTTACTGATCTC -3'

Para a realização desta mutação foi necessária a introdução de um sítio de restrição (Apal) no meio da seqüência do peptídeo de trânsito de THI1, o que provocou a perda de uma alanina e o acréscimo de dois aminoácidos (glicina e prolina). A fim de verificar se estas modificações não interferem no direcionamento da proteína, foi realizada uma construção controle, possuindo todas as característica da anterior, sem conter a mutação da serina. Neste caso, o fragmento amplificado foi o seguinte:

- THISERcont:

Novamente, foram necessárias duas amplificações.

SERcont = fragmento de $136 \mathrm{pb}$.

THI2: descrito anteriormente

THISERcont: 5'- CCCGGGCCCGCGAACGGCGAAAGATCG -3'

SER' = fragmento de $184 \mathrm{pb}$ (descrito anteriormente).

Primeiramente, os fragmentos S43A e SERcont foram digeridos com as enzimas Apal e Kpnl e clonados nos respectivos sítios do plasmídeo SK(-) (Stratagene), resultando nos vetores SK(-)S43A e SK(-)SERcont. Após a análise das colônias transformadas, os plasmídeos foram extraídos e digeridos com Apal e Spel para a clonagem do fragmento SER' em fase de leitura, o que resultou nas construções SK(-)S43A-SER' e SK(-)SERcont-SER'. Para facilitar a clonagem destas construções em pCAMBIA1302 (Roberts et al., 1997), a partir destes plasmídeos foram amplificados, com os primers THIBgl e THI50Spe (descritos anteriormente), fragmentos com os sítios de restrição Bg/l e Spel nas extremidades. 
Foi realizada também a quebra da estrutura em $\alpha$-hélice anfifílica formada a partir da segunda metionina da proteína THI1. Para tanto foi necessária a troca dos aminoácidos carregados positivamente (2 argininas) por aminoácidos neutros (glicinas). Um sítio para a enzima Clal presente na seqüência de thi1 foi utilizado para a realização das mutações. Dois fragmentos foram amplificados:

- THI $\alpha$ :

THI $\alpha$ : 5' CCCATCGATCGTGTCACGTGAGATGACGGGAGGG -3'

THI50Spe: descrito anteriormente

- THI50: fragmento já descrito anteriormente.

A estratégia utilizada para a realização desta construção foi um pouco diferente das anteriores. Ambos os fragmentos foram digeridos com a enzima Clal, que cortou o fragmento THI50 ao meio e a extremidade 5' do fragmento THl $\alpha$. Após a digestão, foram colocados em gel de eletroforese de agarose e os fragmentos complementares (THl $\alpha$ e o fragmento de 190 pb, proveniente da digestão de THI50) foram extraídos do gel com o kit QIAEXII da QIAGEN. A seguir foi realizada uma reação de PCR, utilizando-se os primers THIBgl e THI50Spe (já descritos) e $1 \mu$ de cada um dos fragmentos purificados.

O fragmento THI $\alpha$ completo foi então digerido com Bglll e Spel e clonado no vetor pCAMBIA1302 (Roberts et al., 1997) digerido com as mesmas enzimas.

Portanto, para os experimentos com GFP, foram realizadas as seguintes construções:

- pCAMBIA-THI50-GFP: seqüência original que codifica para o peptídeo de trânsito da proteína THI1, seguida de 50 aminoácidos da proteína madura, fusionada ao gene $g f p$; 


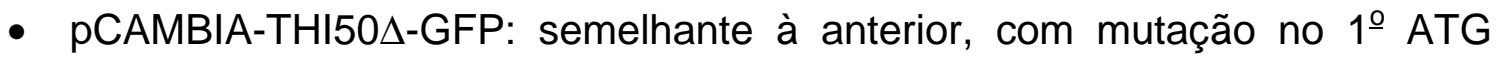
para ATC;

- pCAMBIA-THI50 $\Delta^{\prime}$-GFP: mutação do $2^{\circ}$ ATG para ATC;

- pCAMBIA-MET2-GFP: seqüência correspondente à preseqüência mitocondrial de THI1, com deleção no peptídeo de trânsito cloroplástico;

- pCAMBIA-S43A-GFP: mutação na serina presente no contexto PRSFS para alanina;

- pCAMBIA-SERcont-GFP: controle para a construção anterior, sem mutação na serina;

- pCAMBIA-THI $\alpha$-GFP: quebra da estrutura em $\alpha$-hélice anfifílica formada a partir da segunda metionina.

Alguns controles também foram utilizados:

- pCAMBIA1302 (Roberts et al., 1997): controle citosólico;

- $\beta$-GFP, gentilmente cedido pelo Prof. Marc Boutry e Dr Geoffrey Duby, Université Catholique de Louvain - Bélgica: marcador mitocondrial;

- RecA-GFP (Akashi et al., 1998), gentilmente cedido pelo Dr. Ian Small, INRA, França: marcador cloroplástico;

- SYCO-GFP (Peeters et al., 2000), gentilmente cedido pelo Dr. lan Small, INRA, França: controle mitocondrial e cloroplástico.

\subsubsection{Isolamento e eletroporação de protoplastos de $\mathbf{N}$. tabacum}

Folhas de N. tabacum crescidas in vitro foram pré-plasmolisadas em tampão CPW8 (Frearson et al., 1973) por 30 minutos. Após este período, foram realizados cortes finos e pouco profundos no mesófilo foliar, e as folhas foram incubadas com $5 \mathrm{~mL}$ de solução enzimática [celulase Onozuka 1\% (Merck), macerozima R-10 0,2\% (Yakult) e driselase 0,5\% (Sigma)] por 16 horas, sob leve agitação. 
Os protoplastos isolados foram retirados delicadamente com pipeta Pasteur e filtrados em peneira de malha $64 \mu \mathrm{m}$. O conteúdo filtrado foi transferido para tubos estéreis de centrífuga e centrifugados a aproximadamente $300 \mathrm{Xg}$ por 8 minutos. $\mathrm{O}$ sobrenadante foi cuidadosamente retirado e os protoplastos foram ressuspendidos em CPW8, girando-se o tubo entre as mãos. A centrifugação foi repetida para retirada de toda a solução enzimática e os protoplastos foram ressuspendidos em $1 \mathrm{~mL}$ de meio de eletroporação (asparagina $70 \mathrm{mM}$, gluconato de cálcio $5 \mathrm{mM}$, MES $5 \mathrm{mM}$, manitol 0,4 mM).

Uma alíquota de $0,25 \mathrm{~mL}$ foi retirada e os protoplastos foram contados em hemacitômetro e diluídos a uma concentração de $2 \times 10^{6}$ protoplastos. $\mathrm{mL}^{-1} \cdot 0,8 \mathrm{~mL}$ de protoplastos foram colocados em cuvetas de eletroporação $(0,4 \mathrm{~cm}$ de separação entre os eletrodos, Biorad) e o DNA plasmidial correpondente (de 5 a $50 \mu \mathrm{g}$ ) foi adicionado. A mistura foi incubada no gelo por 10 minutos. Vários experimentos foram realizados a fim de otimizar as condições de eletroporação. Os melhores resultados foram obtidos a 0,16 kVolts e $125 \mu \mathrm{F}$ de capacitância.

Os protoplastos eletroporados foram retirados das cuvetas, transferidos para tubos de centrífuga e incubados a temperatura ambiente no escuro por aproximadamente 48 horas.

A visualização da GFP foi realizada em microscópio de fluorescência (Axiophot 2 - Zeiss), com os filtros FITC (450-490 nm) e H546 (Zeiss). 


\section{RESULTADOS E DISCUSSÃO}

\subsection{THI1 apresenta duas seqüências de direcionamento in tandem}

A proteína THI1 é codificada por um único gene em Arabidopsis thaliana (Machado et al., 1996) e existem evidências de que ela seja uma proteína bifuncional, envolvida na biossíntese de tiamina (vitamina $B_{1}$ ) (Praekelt et al., 1994) e na proteção do material genético mitocondrial (Machado et al., 1997). Interessantemente, estas atividades estão localizadas em dois compartimentos subcelulares distintos: cloroplastos e mitocôndrias. Além disso, o cDNA de thi1 é capaz de complementar parcialmente cepas de leveduras mutantes para o gene homólogo (thi4). Isto é extremamente interessante, uma vez que THI4 é direcionada para mitocôndrias em S. cereviseae, onde ocorre a biossíntese de tiamina (Praekelt et al., 1994). Estes dados sugerem que a proteína THI1 pode ser direcionada simultaneamente tanto para cloroplastos quanto para mitocôndrias.

THI1 apresenta um peptídeo de trânsito cloroplástico na extremidade amino-terminal, que é observado em outros genes ortólogos (Belanger et al., 1995; Ribeiro et al., 1996; Jacob-Wilk et al., 1997; Kim et al., 1998). Uma análise detalhada da região 5' do mRNA de thi1 revela a presença de dois AUGs em fase de leitura que potencialmente poderiam ser usados para iniciação da tradução. A observação da estrutura secundária formada pelos 11 resíduos posteriores à segunda metionina (codificados a partir do segundo AUG) revela um potencial para formar uma $\alpha$-hélice anfifílica, com aminoácidos hidrofóbicos de um lado e carregados positivamente do outro, (Figura 6b), que é 
a estrutura típica das preseqüências mitocondriais (Neupert, 1997; Glaser et al., 1998).

a)

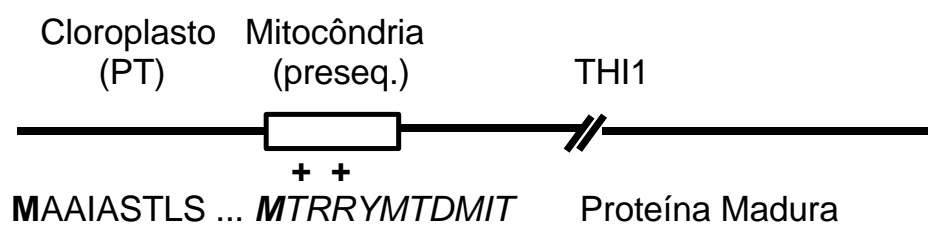

b)

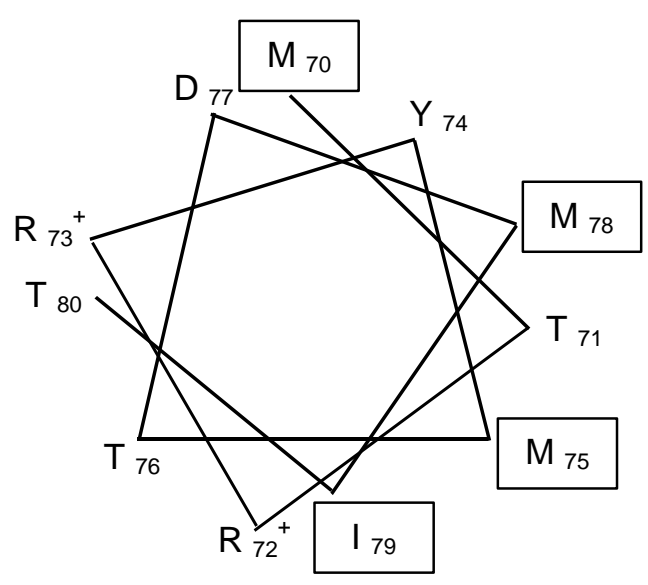

Figura 6 - Representação esquemática da extensão amino-terminal de THI1 de Arabidopsis thaliana. a) As metioninas resultantes dos códons de iniciação da tradução estão em negrito. b) Representação da estrutura em $\alpha$-hélice anfifílica formada pela região compreendida entre os aminoácidos 70-80. Os resíduos hidrofóbicos estão em caixas e os carregados positivamente estão indicados.

A presença desta estrutura em algumas proteínas direcionadas aos cloroplastos tem sido observada (Flügge et al., 1989; .Dreses- Werringloer et al., 1991; Willey et al., 1991; Knight \& Gray, 1994). No entanto, estas proteínas não foram encontradas em mitocôndrias de plantas in vivo (Brinck et 
al., 1994; Silva-Filho et al., 1997, Silva-Filho, 1999). Isso poderia sugerir que a proteína THI1 apresenta duas seqüências de direcionamento em sua extremidade amino-terminal, um peptídeo de trânsito cloroplástico seguido de uma preseqüência mitocondrial (Figura 6a). Entretanto, esta possibilidade é remota uma vez que foi mostrado anteriormente que quando seqüências de direcionamento mitocondriais e cloroplásticas são colocadas em tandem, em ambas orientações, aquela localizada na extremidade $\mathrm{N}$-terminal exerce o papel preponderante na determinação da especificidade (Silva-Filho et al., 1996).

\subsection{Um único gene potencialmente codifica as isoformas cloroplástica e mitocondrial}

A fim de verificar se THI1 é direcionada simultaneamente para cloroplastos e mitocôndrias in vivo, foi desenvolvido um anticorpo policlonal contra a proteína THI1 purificada a partir da expressão heteróloga em bactéria. A especificidade deste anticorpo foi duplamente testada em extrato de $E$. coli expressando THI1 (Figura 7a) e em extrato de proteínas foliares de A. thaliana (Figura 7b).

Uma proteína com o tamanho esperado $(\sim 33 \mathrm{kDa})$ foi detectada pelo anticorpo nas preparações de E. coli, confirmando que o anticorpo é específico para THI1. No entanto, as bandas reveladas pela análise via "western blot" em $A$. thaliana possuem um peso molecular maior que o esperado para esta proteína (Chabregas et al., 2001). Este resultado se repete quando o experimento é realizado com as frações enriquecidas de cloroplastos e mitocôndrias de tabaco (dados não mostrados). Provavelmente, isto pode ser explicado por modificações pós-traducionais que ocorrem em condições in vivo, que podem aumentar o peso molecular da proteína. 


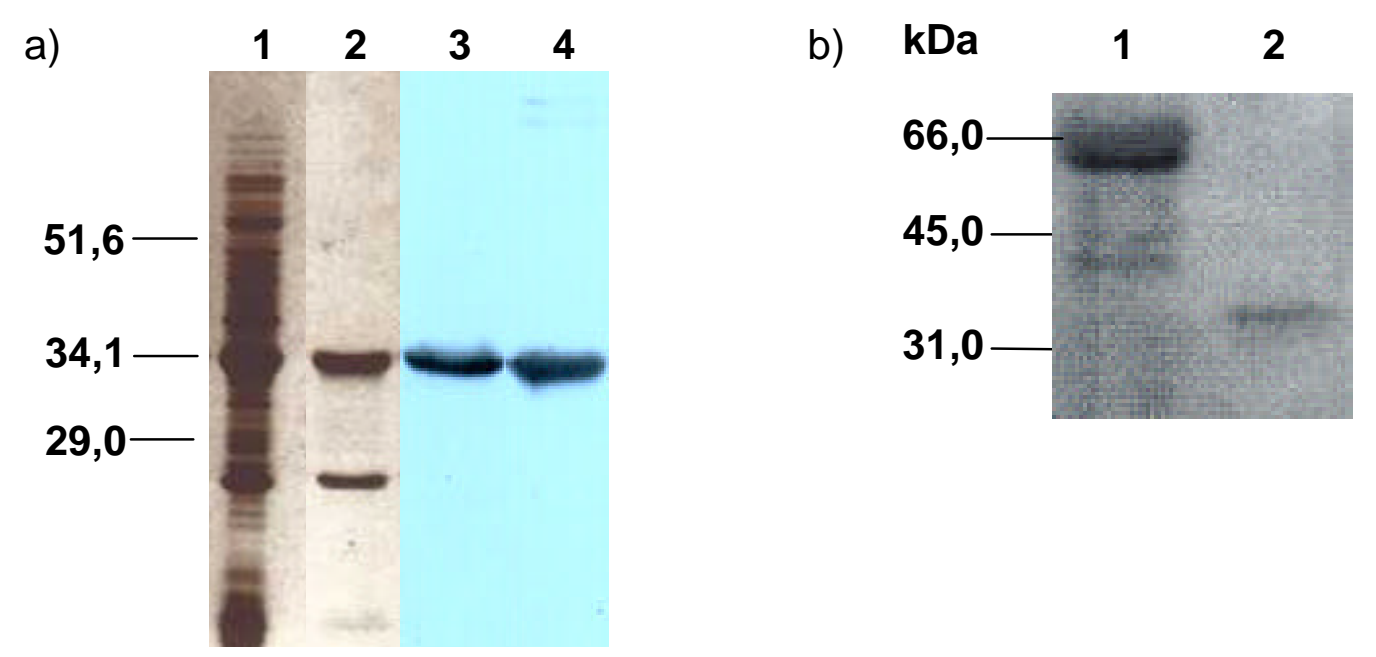

Figura 7 - Imunodetecção de THI1 em E. coli e A. thaliana. a) Extrato protéico de E. coli $(50 \mu \mathrm{g})$ superexpressando THI1 (linha 1), purificado através de uma coluna de afinidade $(5 \mu \mathrm{g}$ ) (linha 2), analisado em gel de poliacrilamida $15 \%$ e colorido com azul de comassie (linhas 1 e 2). Imunodetecção de THI1 no extrato de E. coli (linha 3) e THI1 purificada (linha 4) (experimento realizado por Douglas D. Luche). b) Imunodetecção de THI1 em um extrato de proteínas de $A$. thaliana (linha 1) e THI1 purificada (linha 2).

Uma vez que não foi possível comprovar a presença de THI1 nas frações subcelulares das plantas, optou-se por realizar um experimento de imunolocalização in situ. Conforme esperado, os experimentos de imunolocalização de THI1 em plantas jovens de $A$. thaliana revelaram que a proteína está presente tanto em cloroplastos quanto em mitocôndrias (Figura 8) com insignificante marcação em outras partes da célula. Estes resultados indicam que THI1 é direcionada simultaneamente para cloroplastos e mitocôndrias. 


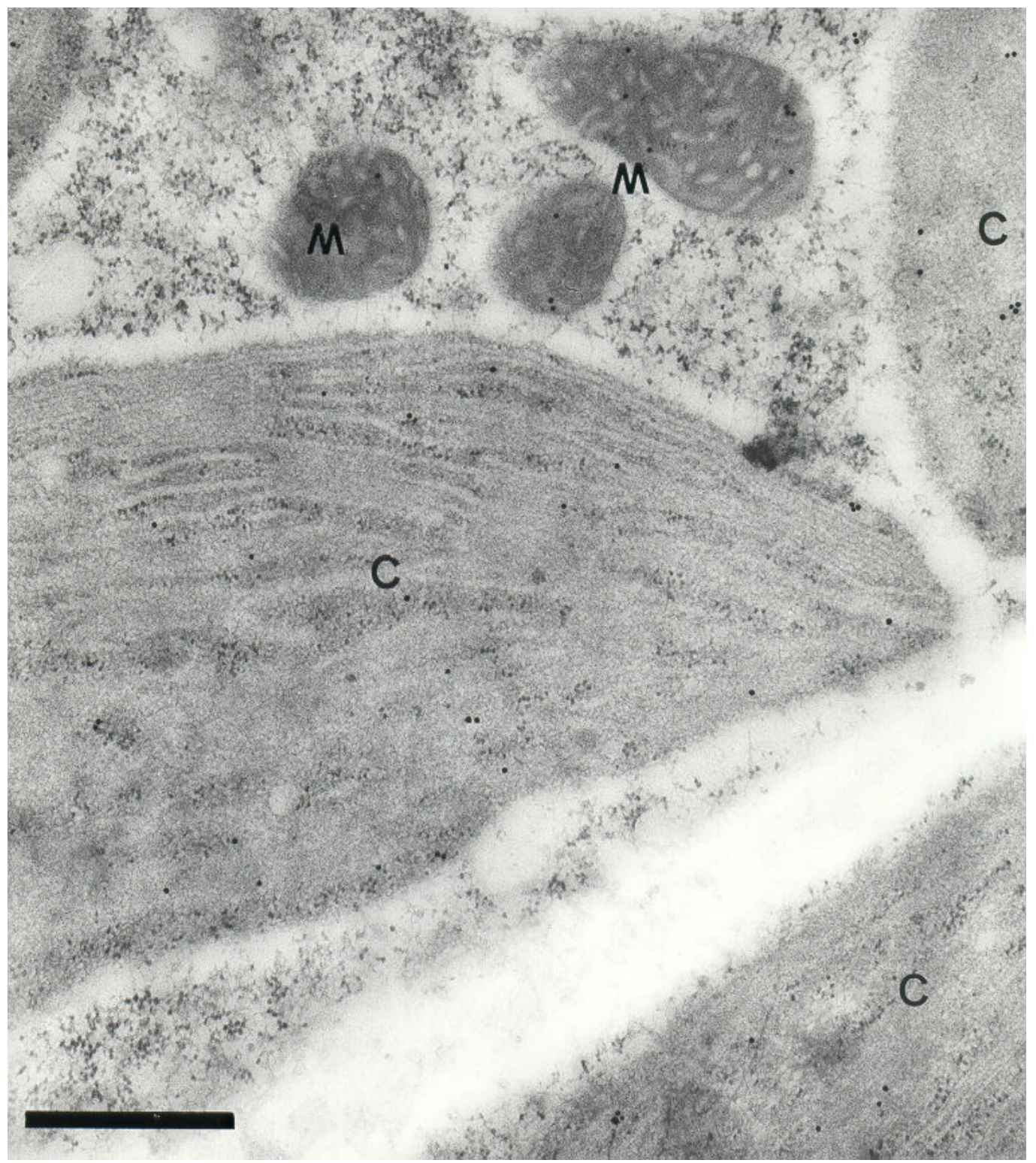

Figura 8 - Imunolocalização de THI1 em células de $A$. thaliana fixadas em aldeído, tratadas com anti-THI1 e anticorpo secundário conjugado a partículas de ouro. Os pontos indicam partículas de ouro de $15 \mathrm{~nm}$ em cloroplastos (C) e mitocôndrias (M). Barra $=0,5 \mu \mathrm{m}$. Experimento realizado por Alberto A. Ribeiro, conforme descrito em material e métodos. 


\subsection{Efeito da $\alpha$-hélice anfifílica no direcionamento de THI1 às mitocôndrias}

A fim de avaliar o papel da estrutura em $\alpha$-hélice anfifílica no direcionamento para mitocôndria, duas construções gênicas foram realizadas (Chabregas et al., 2001). A proteína THI1 madura foi substituída pela proteína repórter GUS, uma vez que já foi previamente demonstrado que, de acordo com a seqüência de direcionamento, GUS é especificamente direcionado para mitocôndrias e cloroplastos (Silva-Filho et al., 1996). As construções preparadas foram as seguintes: THI4-GUS, que corresponde ao peptídeo de trânsito de THI1 retendo ainda a seqüência que codifica para os primeiros 4 resíduos da proteína madura, que podem ser requeridos para seu processamento no interior da organela, fusionados ao gene uidA (GUS) (Figura 9a); e THI27-GUS, contendo além do peptídeo de trânsito, mais 27 resíduos da proteína madura, incluindo a estrutura em $\alpha$-hélice anfifílica, também fusionados à GUS (Figura 9b).

Uma vez que experimentos de importação de proteínas in vitro não constituem um bom sistema para estudo de especificidade (Silva-Filho et al., 1997), as construções THI4-GUS e THI27-GUS foram equipadas com o promotor constitutivo 35S do vírus do mosaico da couve-flor e com a região 3' não codante da pequena subunidade da Rubisco de ervilha. Os genes quiméricos foram introduzidos em plantas de fumo ( $N$. tabacum), usando um vetor derivado do plasmídeo ti de Agrobacterium tumefaciens. Várias plantas independentes foram obtidas e suas frações subcelulares (mitocôndrias e cloroplastos) caracterizadas para cada uma das construções.

O fracionamento subcelular das plantas transgênicas foi realizado a partir da homogeneização de folhas de tabaco seguida por uma centrifugação para obter-se o sobrenadante citosólico e o precipitado organelar. As frações enriquecidas de cloroplastos e mitocôndrias foram obtidas por centrifugação diferencial e subseqüente purificação das organelas em gradiente de Percoll. A fim de avaliar a qualidade e o grau de pureza das preparações, as frações 
enriquecidas de mitocôndrias e cloroplastos foram testadas com anticorpos dirigidos contra proteínas marcadoras destas organelas, notadamente a pequena subunidade da Rubisco, e a lipoamida desidrogenase (LDH), encontrada na matriz mitocondrial (Silva-Filho et al., 1996) (Figura 10a).

a) THI4-GUS

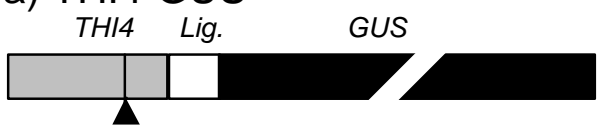

AAGCTTCAAAATGGCTGCCATAGCTTCT M A A I A S АСТСТСТСТСТTTCTTCAACCAAACCTCAG

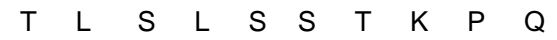
AGACTTTTCGATTCTTCCTTCCATGGCTCA

$R \quad L \quad F \quad D \quad S \quad S \quad F \quad H \quad G \quad S$ GCCATCTCCGCAGCTCCTATCTCCATCGGT

$A$ I S A A P I S I G CTCAAACCACGATCTTTCTCCGTTCGCGCC

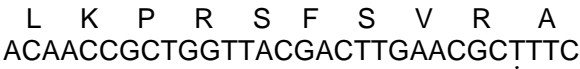
$\begin{array}{llllllllllll}T & T & A & G & Y & D & L & N & A \triangle & F\end{array}$ ACGTTCGACCCAAGCTTGCGGGGTGGTCAG

T F D $P$ S $L R \quad G \quad G Q$ TCCCTTATG

$S \quad L \quad M$ b) THI27-GUS
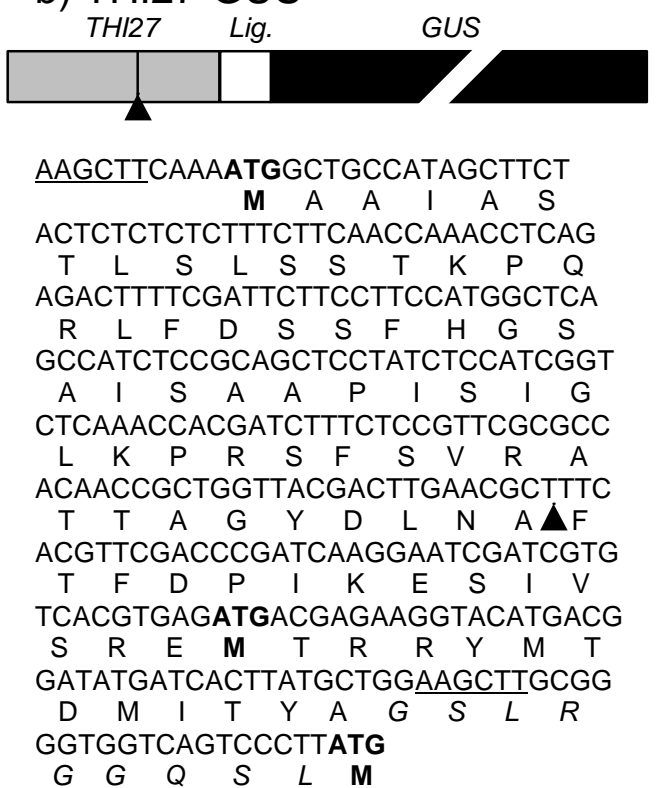

Figura 9 - Construções gênicas THI4-GUS (a) e THI27-GUS (b). Abaixo dos esquemas são mostradas as seqüências de nucleotídeos e aminoácidos do peptídeos de trânsito de THI1, a parte da proteína madura utilizada e a região de ligação até o ATG do gene uidA. Os aminoácidos da região de ligação estão em itálico, os códons de iniciação da tradução estão em negrito e a seta vertical indica o ponto de clivagem do peptídeo de trânsito.

O máximo de enriquecimento obtido para uma proteína direcionada para os cloroplastos é de 2 vezes, assumindo que as proteínas cloroplásticas representam cerca de $50 \%$ das proteínas solúveis do mesófilo foliar. Por outro lado, LDH, o marcador mitocondrial, foi encontrado em altos 
níveis na fração enriquecida de mitocôndrias, mas ausente na fração enriquecida de cloroplastos. Todavia, uma certa quantidade de Rubisco foi encontrada nas frações mitocondriais, conforme observado previamente (SilvaFilho et al., 1997). Isto deve-se ao fato de uma parte significativa dos cloroplastos é quebrada durante o processo de homogeneização liberando proteínas no meio, o que torna essencial o uso de marcadores organelares para estimar a contaminação cruzada.

a)

Rubisco

$\mathrm{LDH}$

c)
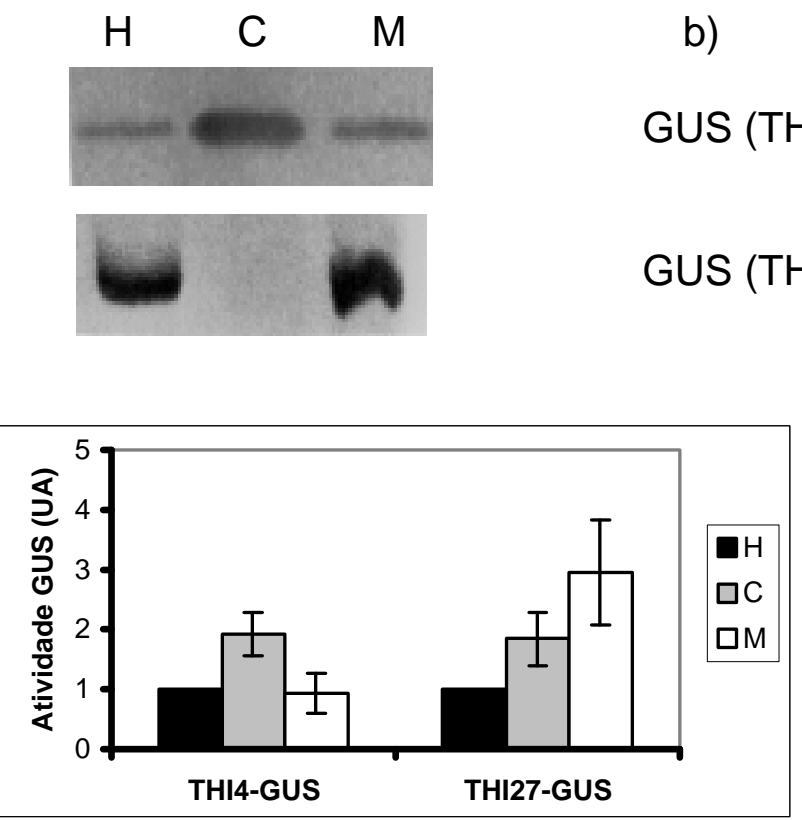

Figura 10 - Detecção da atividade GUS em frações subcelulares das plantas transgênicas. Homogeneizado $(H)$, cloroplasto $(C)$ e mitocôndria (M). a) Imunodetecção de proteínas marcadoras das organelas: Rubisco (topo) e LDH (base). b) Gel de atividade GUS de THI4GUS (topo) e THI27-GUS (base). c) Atividade GUS específica nas frações subcelulares, determinada por fluorimetria. A distribuição da atividade GUS nas frações foram expressas em unidades arbitrárias com base na atividade observada no homogeneizado $(H)$. Os resultados são médias de 3 a 4 preparações independentes +/- desvio padrão. 
A análise da atividade GUS através de gel de eletroforese incubado com o substrato fluorescente para a $\beta$-glucuronidase (MUG), para as plantas THI4-GUS mostrou que a proteína repórter foi direcionada somente para os cloroplastos, com um enriquecimento similar ao da Rubisco para esta fração (Figura 10b). A presença de uma pequena atividade na fração mitocondrial pode ser devida à contaminação por proteínas cloroplásticas, como observado para o marcador (Rubisco). O processamento da proteína quimérica no interior dos cloroplastos ocorreu no sítio esperado e nenhuma atividade GUS foi observada nas plantas não transformadas. Por outro lado, as plantas THI27GUS mostraram atividade em ambas as frações enriquecidas de cloroplastos e mitocôndrias (Figura 10b). Para cada construção, foram encontradas variações na atividade GUS de planta para planta, o que provavelmente representa efeito de posição. No entanto, a distribuição geral da atividade nas frações subcelulares foi similar para plantas expressando a mesma construção (Chabregas et al., 2001).

A atividade GUS também foi determinada por fluorimetria nas frações subcelulares das plantas transgênicas. A distribuição da atividade GUS específica em cada fração foi expressa com base na atividade observada no homogeneizado. A análise das frações enriquecidas com cloroplastos ou com mitocôndrias, torna possível dimensionar o direcionamento para cada organela. A análise da atividade enzimática GUS nas plantas THI4-GUS mostra que a proteína repórter foi direcionada para cloroplastos, uma vez que GUS e Rubisco tiveram enriquecimento similar na fração cloroplástica (Figura 10c). Não houve enriquecimento na fração mitocondrial. Com as plantas THI27-GUS, a análise confirma a presença de GUS tanto em cloroplastos quanto em mitocôndrias. Sendo assim, o peptídeo de trânsito de THI1 seguido de apenas 4 resíduos da proteína madura não é suficiente para endereçar GUS às mitocôndrias. $O$ direcionamento mitocondrial parece ser conferido pela seqüência posterior ao segundo ATG (Chabregas et al., 2001). 


\subsection{THI1 é codificado por um único transcrito nuclear}

Uma análise detalhada da região 5' do cDNA de thi1 revelou a presença de um segundo ATG em fase de leitura, localizado 217 pb após o primeiro ATG utilizado para iniciação da tradução da isoforma cloroplástica. Assim, a iniciação da tradução a partir deste segundo ATG pode gerar uma isoforma diferente com uma extensão amino-terminal típica de preseqüências mitocondriais.

Para investigar se a presença de múltiplos transcritos com extremidades 5' variáveis poderiam estar envolvidos na regulação do direcionamento da proteína, o mapeamento da extremidade $5^{\prime}$ de thi1 foi realizado por meio de um experimento de 5'-RACE (Frohman et al., 1988) e pela análise de proteção à nuclease $S 1$ (Figura 11). Um total de 63 produtos clonados via 5'-RACE foram analisados em gel de eletroforese. Destes, 58 fragmentos suportam a iniciação da transcrição no sítio -39 , em relação ao primeiro ATG. Os outros clones revelaram um sítio de iniciação da transcrição nas posições $+32,+74,+113,+146$ e +150 . Estes fragmentos não constituem uma segunda população de mRNA, mas provavelmente são resultado de um desacoplamento casual da transcriptase reversa in vitro (Chabregas et al., 2001).

Para o experimento de análise de proteção à nuclease $\mathrm{S} 1$, a sonda de cDNA empregada de 402 pb cobre ambos os códons AUGs (Figura 11a). A sonda foi hibridizada com RNA total de plantas jovens de A. thaliana, seguido por digestão com nuclease S1. O fragmento protegido foi então analisado por gel de eletroforese de seqüenciamento. Os resultados (Figura 11b) indicam a presença de um único fragmento protegido com início na posição -39 do primeiro ATG. Transcritos menores não foram detectados. Portanto, os dois experimentos sugerem que as isoformas mitocondrial e cloroplástica de THI1 são derivadas de um único transcrito (Chabregas et al., 2001). Análise da seqüência de nucleotídeos ao redor do sítio de iniciação da 
transcrição está de acordo com as encontradas para outros genes de plantas (Joshi, 1987).

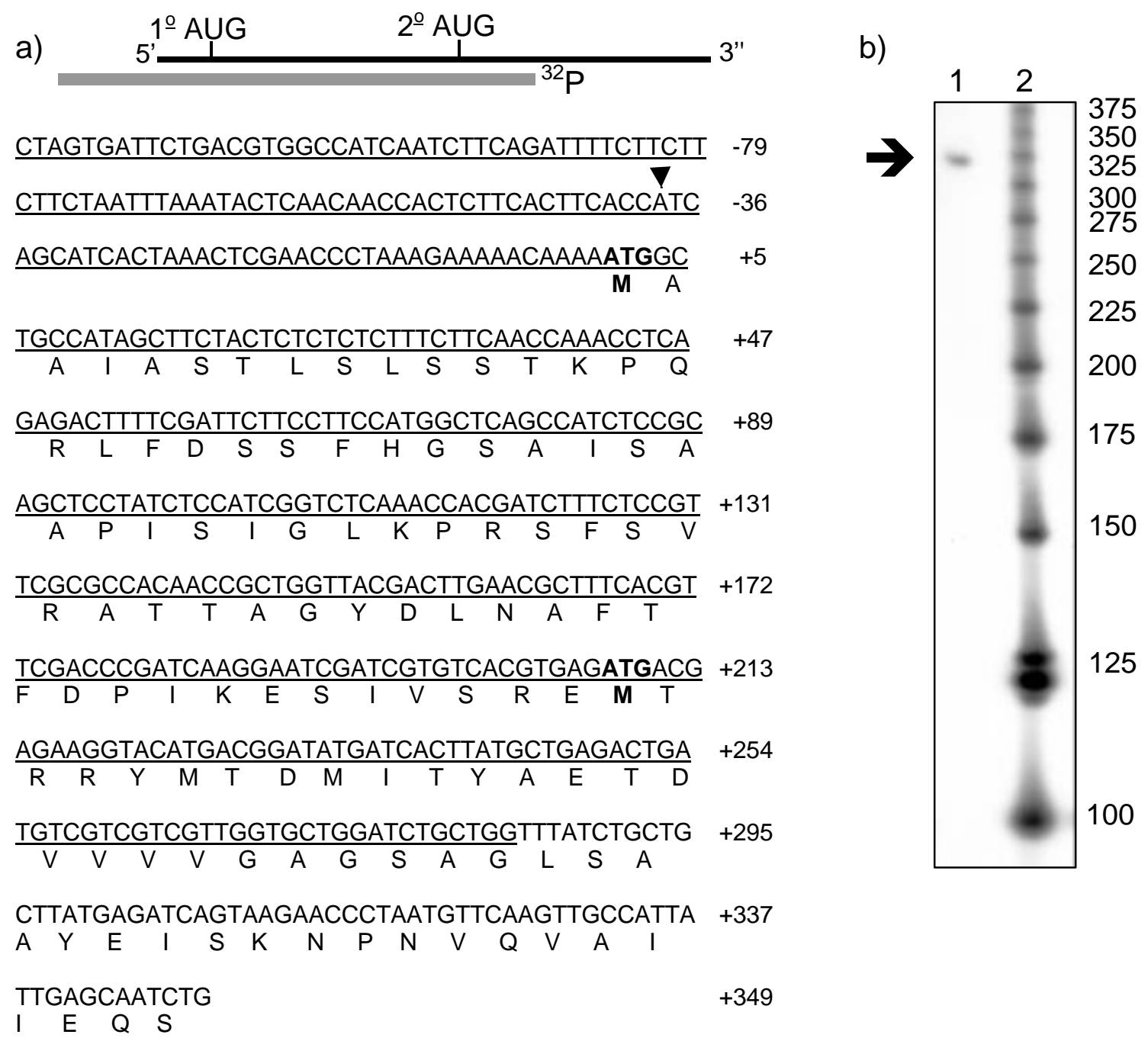

Figura 11 - Mapeamento da extremidade $5^{\prime}$ do transcrito de thi1 com nuclease S1. a) Representação esquemática do mRNA de thi1 (linha fina) e da sonda de $402 \mathrm{pb}$ marcada com ${ }^{32} \mathrm{P}$ (linha cinza). Na seqüência genômica está indicado a região de anelamento da sonda (sublinhado) e a posição de iniciação da transcrição (seta). b) Fragmento da região $5^{\prime}$ de $323 \mathrm{pb}$ protegido da digestão com nuclease S1 (linha 1, indicado pela seta) e marcador de peso molecular (linha 2, 25 pb DNA ladder). Experimento realizado por Leonardo P. Farias, conforme descrito em material e métodos. 
Tem sido observado um crescente aumento no número de proteínas multicompartimentalizadas codificadas por um único gene em células eucarióticas (Danpure, 1995; Small et al., 1998). Os mecanismos que tornam este processo possível envolvem formas alternativas de iniciação da transcrição ou da tradução, processamento alternativo do transcrito e modificações póstraducionais, conforme detalhado na introdução. A maioria dos estudos envolvendo proteínas multicompartimentalizadas envolvem o citosol, compartimento que não é dependente de qualquer sinal de direcionamento, e uma organela. Um exemplo interessante é o duplo direcionamento da alaniltRNA-sintetase de $A$. thaliana para citosol e mitocôndrias a partir da tradução diferencial de um único transcrito, contendo dois códons de iniciação (Mireau et al., 1996). De maneira similar, o gene da FPS1 de $A$. thaliana também determina a localização citosólica e mitocondrial da proteína pelo uso de dois códons AUG em fase de leitura (Cunillera et al., 1997). Este mecanismo pode ser o responsável pela localização de THI1 em cloroplastos e mitocôndrias.

Alguns poucos exemplos, onde um único gene produz transcritos com diferentes extremidades $5^{\prime}$ que podem dar origem a isoformas com localizações subcelulares distintas, são encontrados em células de plantas (Cunillera et al., 1997; Wimmer et al., 1997). No entanto, esta estratégia não pode explicar o duplo direcionamento de THI1, uma vez que os dados obtidos sugerem a existência de um único transcrito (Chabregas et al., 2001).

A ocorrência de dois sinais de direcionamento em uma mesma proteína é muito menos freqüente. No caso de um gene artificial, criado pela fusão de uma preseqüência mitocondrial e um peptídeo de trânsito cloroplástico fusionados em ambas as orientações com uma proteína repórter, foi verificado que a seqüência mais próxima à região amino-terminal determina a localização final da proteína (Silva-Filho et al., 1996). Parece que a seqüência da região amino-terminal afeta sobretudo o acesso ao segundo sinal de direcionamento (Danpure, 1995). Isto indica que quando dois sinais de direcionamento estão 
presentes, estabelece-se uma competição de um com o outro (Small et al., 1998).

A existência de dois sinais de direcionamento em THI1 é bastante provável. Outra hipótese seria a presença de um único peptídeo ambíguo, que poderia ser reconhecido pela maquinaria de importação das duas organelas. Vários fatores de ligação a preseqüências mitocondriais foram isolados de diferentes organismos, assegurando importação específica nesta organela (Murakami et al., 1992; Hachiya et al., 1993; Cartwright et al., 1997). Recentemente, foi reportado que proteínas 14-3-3 formam um complexo com precursores cloroplásticos (May \& Soll, 2000). Além disso, o peptídeo de trânsito cloroplástico é fosforilado (Waegemann \& Soll, 1996) e as preseqüências mitocondriais não.

\subsection{THI1 apresenta dois sítios de iniciação da tradução}

Uma característica bastante interessante de thi1 é a presença de dois ATGs em fase de leitura, ambos com potencial para constituir um sítio de início da tradução. No caso de um início alternativo, serão produzidas proteínas com diferentes extremidades amino-terminais, o que poderia explicar a compartimentalização diferencial de THI1 no interior da célula.

A fim de investigar esta hipótese foram realizadas algumas construções gênicas com mutações pontuais nas seqüências de direcionamento (Figura 12a), utilizadas em experimentos de transcrição e tradução in vitro (Figura 12b). Os dados obtidos indicam que o segundo AUG de thi1 constitui um sítio de iniciação da tradução, no entanto existe uma preferência bastante significativa em relação ao início no primeiro AUG (Figura $12 b$, coluna 1$)$.

Quando o primeiro AUG é mutado para AUC, abolindo o sítio de iniciação, somente é observada a proteína de $75 \mathrm{kDa}$, traduzida a partir do segundo AUG (Figura 12b, coluna 2). É possível detectar ainda uma 
porcentagem muito pequena de iniciação no primeiro AUG (mutado para AUC), no entanto isto constitui um artefato da técnica de transcrição e tradução in vitro, conforme relatado por Kozak (1999). O mesmo é observado quando a mutação ocorre no segundo AUG (Figura 12b, coluna 3).

a)

\begin{tabular}{|r|c|l|}
\hline PT & M & \multicolumn{1}{c|}{ GUS } \\
\hline ATG... & ATG... & ATG... \\
\end{tabular}

\begin{tabular}{|c|c|cc|}
\hline PT & M & \multicolumn{2}{c|}{ GUS } \\
\hline ATC... & ATG... & ATG... & \\
\hline
\end{tabular}

\begin{tabular}{|c|c|c|}
\hline PT & M & GUS \\
\hline \multirow[t]{2}{*}{ ATG... } & ATC... & ATG... \\
\hline & & GUS \\
\hline
\end{tabular}

b)

\begin{tabular}{|c|c|}
\hline Início da tradução: & Proteína de: \\
\hline $1^{\circ} \mathrm{AUG} \ldots \ldots \ldots \ldots \ldots . . . . . . . .$. & $\ldots \ldots .83 \mathrm{kDa} \rightarrow$ \\
\hline $\begin{array}{l}2^{\circ} \text { AUG.. } \\
\text { AUG do }\end{array}$ & $\ldots .70 \mathrm{~kL}$ \\
\hline
\end{tabular}

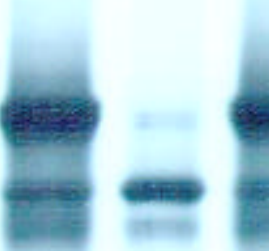

SK(-)THI64-GUS (1)

SK(-)THI64A-GUS (2)

SK(-)THI64 $\Delta^{\prime}-$ GUS (3)

SK(-)GUS (4)

\section{$\begin{array}{llll}1 & 2 & 3 & 4\end{array}$}

Figura 12 - Mutações nos sítios de iniciação da tradução. a) Esquema representando as construções gênicas realizadas, conforme detalhado em material e métodos. b) Experimento de transcrição e tradução in vitro, realizado por Douglas D. Luche. 1- SK(-)

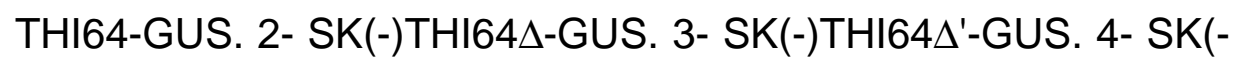
)GUS (controle). Os respectivos tamanhos das proteínas traduzidas a partir do $1^{\circ}$ AUG ou $2^{\circ}$ AUG e do GUS estão indicados. 
A iniciação no segundo AUG é um evento bastante interessante uma vez que geralmente a tradução de um proteína inicia-se unicamente no primeiro AUG (Kozak, 1991a). Casos raros de iniciação da tradução no segundo AUG ocorrem quando os dois AUGs encontram-se muito próximos, fazendo com que a subunidade menor do ribossomo (40S) reconheça igualmente os dois sítios para iniciar a tradução (Kozak, 1995). Isto provavelmente não ocorre com thi1, visto que os dois AUGs estão separados por 204 nucleotídeos. Uma outra possibilidade é de que o primeiro AUG esteja localizado muito próximo ao "cap" (extremidade 5'), dificultando o acesso da subunidade ribossomal. Além disso, a presença de um contexto subótimo para início da tradução no primeiro AUG ou mesmo a presença de estrutura secundária na forma de grampo podem levar a tradução para o segundo AUG (revisado por Kozak, 1999).

Outros casos são observados quando o primeiro AUG encontra-se inserido em um contexto pior que o segundo, dessa forma a subunidade $40 \mathrm{~S}$ "passa" pelo primeiro AUG sem reconhecê-lo como um sítio para iniciação, indo parar no segundo AUG (Kozak, 1995). Segundo Joshi e colaboradores (1997), a seqüência consenso em plantas é AACAAUGGC. Ou seja, uma purina na posição -3 (preferencialmente uma Adenina) e uma Guanina na posição +4. No caso de thi1 o contexto em que está inserido o primeiro AUG (AAAAUGGC) é melhor que 0 do segundo (GAGAUGAC). A fim de verificar mais detalhadamente $o$ efeito dos contextos dos dois $A U G$ s de thi1 sobre a iniciação da tradução, outras construções foram realizadas para análise da transcrição e tradução in vitro (Figura 13).

O contexto ao redor dos AUGs foi alterado, tornando o primeiro pior em relação ao consenso (de AAAAUGGC para CAAAUGCC) e melhorando o segundo (de GAGAUGAC para ACCAUGGC). É possível perceber uma forte influência do contexto para iniciação da tradução no primeiro AUG, uma vez que quando ele é mutado para pior, ocorre uma redução bastante significativa na síntese da proteína de $83 \mathrm{kDa}$, sintetizada a partir do $1^{\circ}$ AUG (Figura 13b, 
coluna 1). No entanto, ao contrário do esperado, quando o contexto ao redor do segundo AUG é alterado para melhor, não é observado aumento da tradução neste sítio. Isto poderia sugerir a presença de elementos cis no mRNA que dificultariam a tradução a partir do segundo AUG.

a)

\begin{tabular}{|c|c|cc|}
\hline PT & $M$ & & GUS \\
CAAATGC... & ATG... & ATG... \\
\hline PT & $M$ & & GUS \\
\hline
\end{tabular}

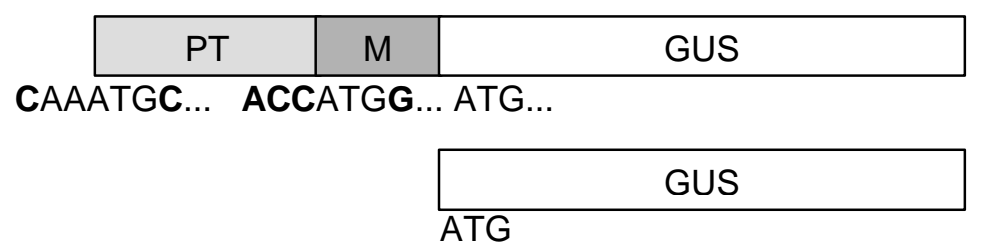

b)

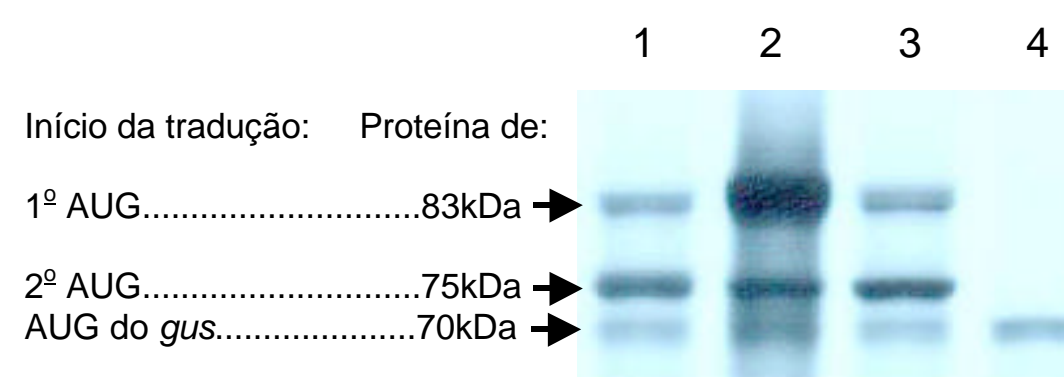

SK(-)THI641 $\Delta$-GUS (1)

SK(-)THI642D-GUS (2)

SK(-)THI6412L-GUS (3) SK(-)GUS (4)

4

Figura 12 - Mutações nos contextos ao redor dos códons de início da tradução. a) Esquema representando as construções gênicas realizadas, conforme detalhado em material e métodos. b) Experimento de transcrição e tradução in vitro, realizado por Douglas D. Luche. 1-

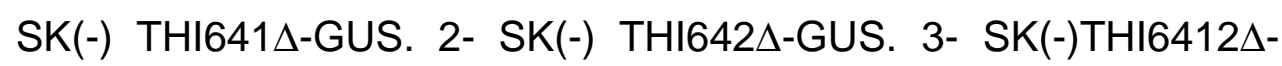
GUS. 4- SK(-)GUS (controle). Os respectivos tamanhos das proteínas traduzidas a partir do $1^{\circ} \mathrm{AUG}$ ou $2^{\circ} \mathrm{AUG}$ e do GUS estão indicados. 
A fim de verificar a ocorrência de estrutura secundária no mRNA de thi1, a seqüência foi analisada em programas de predição de estrutura secundária (ver material e métodos para detalhes). Os resultados mostram a presença de uma estrutura estável em forma de grampo que dificulta o acesso do complexo de iniciação da tradução ao segundo AUG (Figura 14).

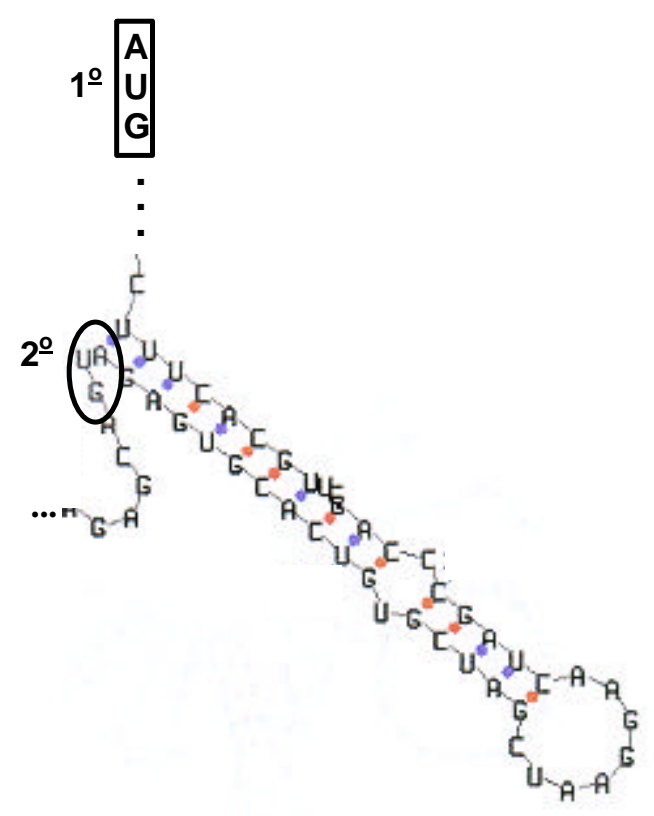

Figura 14 - Predição de estrutura secundária no mRNA de thi1. Os dois AUGs onde ocorre iniciação da tradução estão indicados.

THI1 é traduzida preferencialmente a partir do primeiro AUG (Figura 12b, coluna 1), no entanto, a despeito de um contexto pior e de uma estrutura secundária desfavorável do mRNA, a iniciação da tradução também é observada no segundo AUG. Neste panorama, pode-se especular o que ocorre com o mRNA de thi1 que permite início da tradução a partir do segundo AUG.

O processo de iniciação da tradução é bastante complexo, são necessários vários fatores traducionais, cuja interação correta constitui-se em mais um nível de regulação. Para iniciação da tradução, a região 5' do mRNA 
deve estar livre de qualquer estrutura secundária. Várias proteínas são necessárias, dentre elas a helicase elF4A, que associa-se com 0 fator de iniciação da tradução elF4G, que por sua vez interage com o fator de ligação ao "cap" elF4E, com a proteína de ligação à cauda poli-A (Pab1p) e com o mRNA. Somente depois do recrutamento de todos estes fatores traducionais é que a subunidade $40 S$ une-se ao complexo para realizar a exploração da extremidade 5' do mRNA até encontrar um sítio de iniciação da tradução (Sachs, 2000).

No entanto, este mecanismo "cap"-dependente não é a única forma de iniciação da tradução. A descoberta de sítios internos de entrada do ribossomo (IRES) no mRNA de picornavírus revela que a pequena subunidade ribossomal pode ligar-se diretamente ao mRNA de uma maneira "cap"independente (Jang et al., 1990). Como resultado desta propriedade, os elementos IRES provêm a primeira exceção para o mecanismo geral de iniciação (Sachs, 2000). Estes elementos são geralmente caracterizados por regiões do mRNA que formam estrutura secundária do tipo grampo e aumentam de forma significativa a afinidade dos fatores traducionais ao mRNA (Sachs, 2000). Além de estarem presentes em vírus, IRES foram detectados em outros organismos. No entanto, Kozak (2001) critica duramente a maioria destes trabalhos alegando que os experimentos realizados para identificação destes sítios não foram realizados com controles adequados. No caso de thi1 trata-se de uma hipótese que merece investigação.

Além disso, existem relatos em que a iniciação da tradução no segundo AUG ocorre somente por razões regulatórias (Kozak, 1999). Recentes experimentos sugerem que o mecanismo pelo qual a subunidade $40 \mathrm{~S}$ não reconhece o primeiro $A U G$, pode ser modulado pela fase do desenvolvimento da célula ou temperatura. A temperatura regula a síntese de duas isoformas da FRQ (frequency), um componente central do rítmo circadiano em Neurospora, através da escolha da iniciação da tradução em dois sítios alternativos (Liu et al., 1997). Diferentes formas de NIFS, uma cisteína desulfurase de humanos, com localização subcelular distinta em mitocôndria ou citosol e núcleo, são 
sintetizadas a partir de um único transcrito através da iniciação da tradução em dois AUGs em fase de leitura. A seleção do sítio de iniciação varia de acordo com as condições de $\mathrm{pH}$ do meio ou citosol. Esta nova forma de regulação traducional permite rápida redistribuição desta proteína em diferentes compartimentos em resposta a mudanças nas condições metabólicas (Land \& Rouault, 1998). Estes trabalhos abrem uma nova perspectiva para o estudo do direcionamento da proteína THI1 em função da alteração de condições ambientais. Tratando-se de uma proteína bifuncional e dada as particularidades da tradução em um segundo sítio de iniciação, é bastante provável que THI1 apresente um mecanismo regulatório incomum.

\subsection{A localização subcelular de THl1 é regulada pela iniciação alternativa da tradução}

O mecanismo que controla o duplo direcionamento da proteína THI1 parece ser a utilização de sítios alternativos para iniciação da tradução, uma vez que um único transcrito é produzido e a partir dele são sintetizadas duas proteínas. A proteína traduzida a partir do primeiro AUG possui um peptídeo de trânsito cloroplástico amino-terminal e é direcionada para cloroplastos. O início da tradução a partir do segundo AUG, produz uma proteína com uma preseqüência mitocondrial na extremidade que é direcionada para mitocôndrias.

Para confirmar estas especulações, foram realizadas construções gênicas contendo diferentes mutações na seqüência de direcionamento de thi1, além da troca dos ATGs por ATCs, fusionadas ao gene que codifica para GFP ("green fluorescence protein") (Figura 15). Estas construções foram eletroporadas em protoplastos de tabaco e visualizadas em microscópio de fluorescência (Figura 15a, b, c, d, e). Estes experimentos foram monitorados por controles expressando GFP em compartimento subcelular previamente conhecido (Figura 16). 
filtros sobrepostos

a) PT $M \quad$ GFP
\begin{tabular}{|l|l}
\hline ATG... & ATG...
\end{tabular}

b) $\mathrm{PT} \quad \mathrm{M} \quad \mathrm{GFP}$

\begin{tabular}{|l|l|l|}
\hline & 1 & \\
\hline ATC... & ATG...
\end{tabular}

c) $\mathrm{PT} \quad \mathrm{M}$

\begin{tabular}{|l|l|l|}
\hline \multicolumn{1}{c}{ PT } & GFP \\
\hline ATG... & ATC... &
\end{tabular}

d)

\begin{tabular}{c}
$M \quad$ GFP \\
\hline \multicolumn{1}{c}{1} \\
\hline ATG...
\end{tabular}

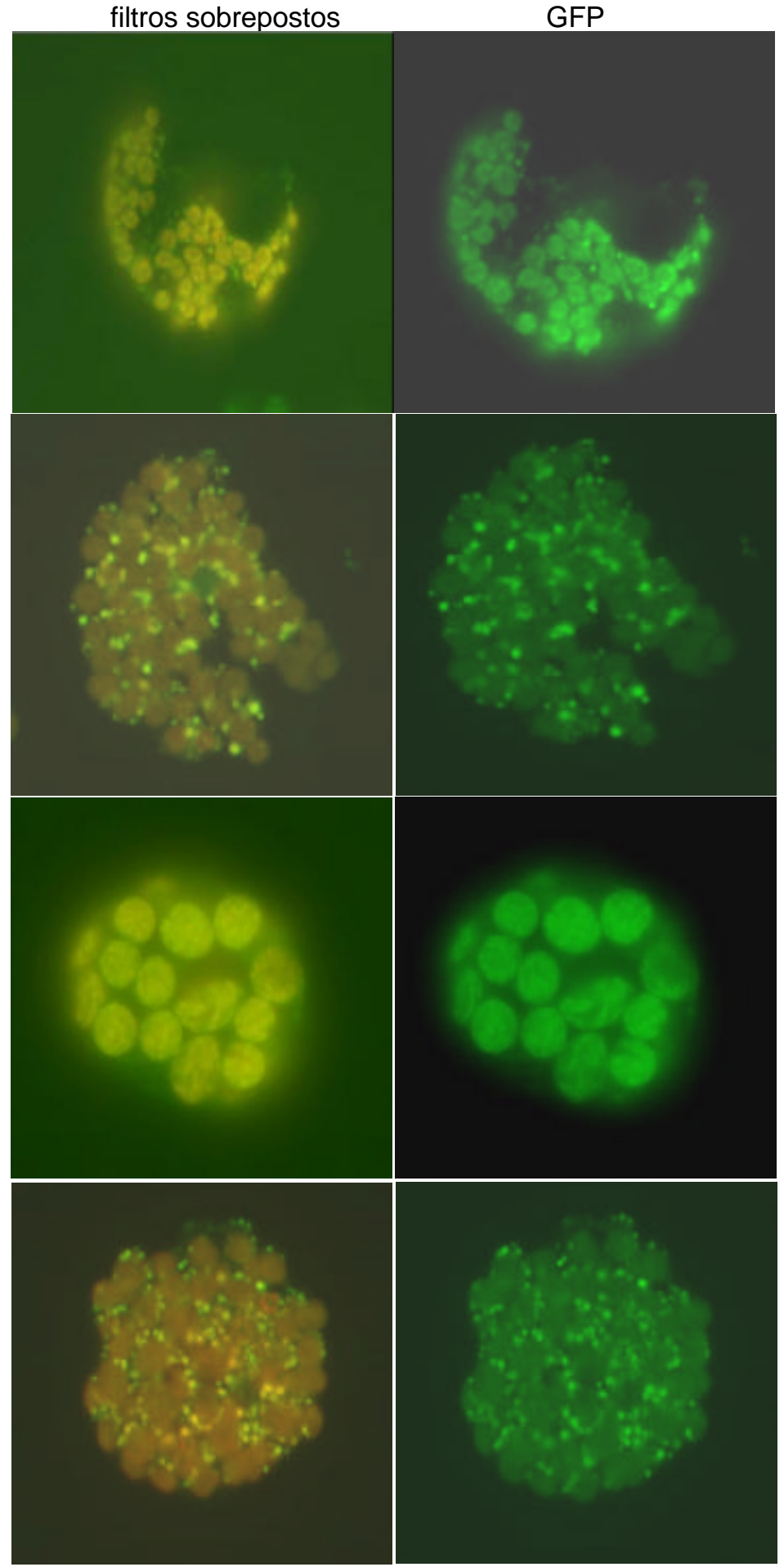


Figura 15 - Transporte de GFP fusionada à seqüência amino-terminal de THI1. a) Seqüência original do peptídeo de trânsito seguido de 50 aminoácidos da proteína madura. b) Mutação no primeiro ATG para ATC. c) Mutação no segundo ATG para ATC. d) Deleção do peptídeo de trânsito. A fluorescência da GFP foi observada em filtro FITC (excitação $470 \mathrm{~nm}$ e emissão $520 \mathrm{~nm}$ ) e a autofluorescência dos cloroplastos em filtro com excitação $540 \mathrm{~nm}$ e emissão $600 \mathrm{~nm}$. As imagens sobrepostas captadas pelos dois filtros e as imagens só de GFP estão indicadas.
a) WT
b) Citosol
c) Cloroplasto
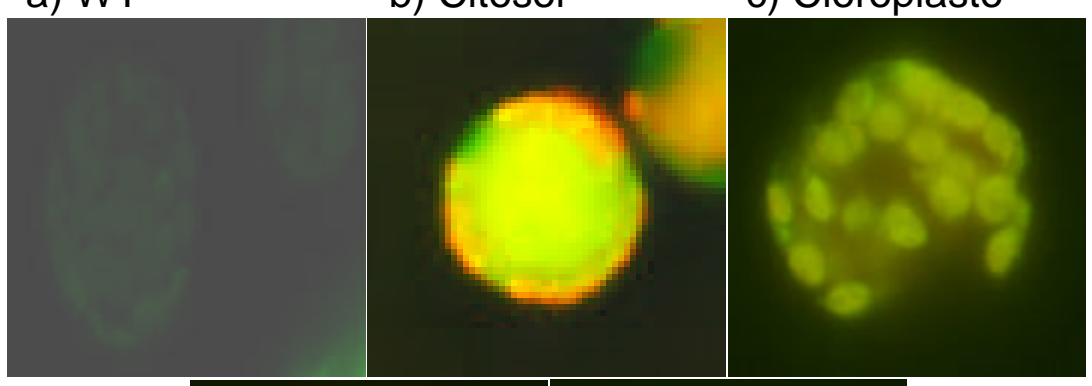

d) Mitocôndria

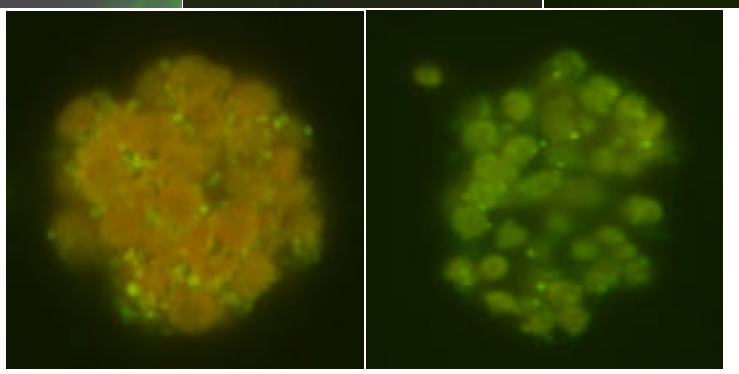

e) Cloroplasto e mitocôndria

Figura 16 - Células expressando fusões de GFP utilizadas como controle. a) WT célula não eletroporada. b) Citosol: pCAMBIA (35S-GFP). c) Cloroplasto: RecA-GFP (Akashi et al., 1998). d) Mitocôndria: $\beta$-GFP (cedido pelo Prof. Marc Boutry). e) Duplo direcionamento para cloroplasto e mitocôndria: SYCO-GFP (Peeters et al., 2000). A fluorescência da GFP foi observada em filtro FITC (excitação 470 nm e emissão 520 nm). 
A construção contendo a seqüência amino-terminal original de THI1 (peptídeo de trânsito mais 64 aminoácidos da proteína madura) foi capaz de direcionar GFP tanto para cloroplastos quanto para mitocôndrias (Figura 15a), confirmando os resultados anteriormente obtidos (Chabregas et al., 2001). Quando o primeiro ATG é mutado para ATC, a proteína começa a ser traduzida a partir da segunda metionina. Esta construção direciona GFP somente para mitocôndrias (Figura 15b). Trata-se de um resultado extremamente interessante que parece confirmar a hipótese levantada. Além disso, um resultado semelhante foi observado quando o peptídeo de trânsito foi deletado completamente (Figura 15d), indicando que a região em $\alpha$-hélice anfifílica realmente constitui uma preseqüência mitocondrial. Ao contrário, quando o segundo ATG foi mutado para ATC a proteína GFP é direcionada somente para cloroplastos (Figura 15c). Estes resultados fortemente sugerem que 0 mecanismo de controle do direcionamento subcelular de THI1 acontece durante a tradução, pelo uso alternativo de dois sítios de iniciação.

Um mecanismo semelhante é observado com a protoporfirinogênio oxidase II (Protox II) de espinafre, a enzima final da biossíntese de clorofila e heme (Watanabe et al., 2001). Este é o único relato presente na literatura atual que descreve o direcionamento de uma proteína para cloroplastos e mitocôndrias pelo uso alternativo de dois códons de iniciação da tradução em fase de leitura. Portanto, a proteína THI1 de $A$. thaliana constitui um caso extremamente raro na natureza.

Unindo a estes dados, que confirmam que o direcionamento de TH11 para mitocôndrias e cloroplastos é regulado em nível traducional, aos resultados obtidos com a tradução e transcrição in vitro, que indicam preferência significativa do início da tradução no primeiro AUG, pode-se especular que a proteína THI1 seja preferencialmente direcionada para cloroplastos, e menos freqüentemente destinada a mitocôndrias. Ou então, haja um efeito do ambiente no sentido de interferir na localização da proteína, conforme observado em outros trabalhos (veja acima). 
O propósito fisiológico para o direcionamento de THI1 para ambas as organelas é pouco conhecido. Existem várias evidências que mostram esta proteína está implicada na biossíntese de tiamina e também na manutenção da estabilidade do genoma organelar depois de um dano ao DNA (Machado et al., 1996, 1997). A tolerância ao dano ao material genético é necessária em ambas as organelas, mas a biossíntese de tiamina parece ocorrer somente em cloroplastos (Belanger et al., 1995). Assim, a existência de dois códons AUGs para iniciação alternativa da tradução pode estar relacionado à necessidade de expressão diferencial de cada função, dependendo das condições do meio ambiente. Se tiamina é o fator limitante, então THI1 seria preferencialmente direcionada aos cloroplastos, sendo o início da tradução principalmente realizado a partir do primeiro AUG. Se o material genético organelar é danificado por algum tipo de estresse, então ambos os códons de iniciação são empregados e as duas isoformas de THI1 são sintetizadas (Chabregas et al., 2001). Assim, os mecanismos que controlam o uso dos dois códons alternativos de iniciação parecem ser bastante complexos, dependendo das condições fisiológicas da célula. 


\section{CONCLUSÕES}

- A proteína THI1 de Arabidopsis thaliana é direcionada para cloroplastos e mitocôndrias in vivo;

- Uma estrutura em $\alpha$-hélice anfifílica presente na região posterior à segunda metionina é responsável pelo direcionamento da proteína às mitocôndrias;

- A localização subcelular da proteína é determinada pelo início alternativo da tradução a partir de dois códons AUG em fase de leitura;

- O contexto ao redor do primeiro AUG é mais favorável para a tradução de THI1;

- O mRNA de thi1 forma uma estrutura secundária bastante desfavorável para inicio da tradução no segundo AUG. 


\section{REFERÊNCIAS BIBLIOGRÁFICAS}

ADAMS, K.L.; DALEY, D.O.; QIU, Y.L.; WHELAN, J.; PALMER, J.D. Repeated, recent and diverse transfers of a mitochondrial gene to nucleus in flowering plants. Nature, v.408, n.6810, p.354-357, 2000.

AKASHI, K.; GRANDJEAN, O.; SMALL, I. Potential dual targeting of an Arabidopsis archaebacterial-like histidyl-tRNA synthase to mitochondria and chloroplasts. FEBS Letters, v.431, n.1, p.39-44, 1998.

BARATA, R.M.; CHAPARRO, A.; CHABREGAS, S.M.; GONZÁLEZ, R.; LABATE, C.A.; AZEVEDO, R.A.; SARATH, G.; LEA, P.J.; SILVA-FILHO, M.C. Targeting of the soybean leghemoglobin to tobacco chloroplasts: effects on aerobic metabolism in transgenic plants. Plant Science, v.155, n.2, p.193202, 2000.

BAR-PELED, M.; BASSHAM, D.C.; RAIKHEL, N.V. Transport of proteins in eukaryotic cells: more questions ahead. Plant Molecular Biology, v.32, n.12, p.223-249, 1996.

BARTLETT, S.G.; GROSSMAN, A.R.; CHUA, N-H. Methods in Chroroplast Molecular Biology. In: EDEIMAN, M.; HALICK, R.B.; CHUA, N-H. (Ed.). In vitro synthesis and uptake of cytoplasmatic-synthesized chloroplast proteins. Amsterdam: Elsevier North-Holland Biomedical Press, 1982. p.1081-1091. 
BAUER, J.; HILTBRUNNER, A.; KESSLER, F. Molecular biology of chloroplast biogenesis: gene expression, protein import and intraorganellar sorting. Cellular and Molecular Life Sciences, v.58, n.3, p.420-433, 2001.

BEDWELL, D.M.; STROBEF, A.S.; YUN, K.; JONGWARD, G.D.; EMR, S. Sequence and structural requeriments of a mitochondrial protein import signal defined by saturation cassete mutagenesis. Molecular and Cell Biology, v.9, n.3, p.1014-1025, 1989.

BEGLEY, T.P. The biosynthesis and degradation of thiamin (vitamin $B_{1}$ ). Natural Production Reports, v.3, n.3, p.177-185, 1996.

BELANGER, F.C.; LEUSTEK, T.; CHU, B.; KRIS, A.L. Evidence for thiamine biossyntetic pathway in higher plant plastids and its developmental regulation. Plant Molecular Biology, v.29, n.4, p.809-821, 1995.

BOUTRY, M.; NAGY, F.; POULSEN, C.; AOYAGI, K.; CHUA, N.H. Targeting of bacterial chloramphenicol acetyltransferase mitochondria in transgenic plants. Nature, v.328, n.6128, p.340-342, 1987.

BRADFORD, M.M. A rapid and sensitive method for the quantification of microgram quantities of protein utilizing the principle of protein-dye binding. Analytical Biochemistry, v.72, n.1-2, p.248-254, 1976.

BRAUN H-P.; SCHMITZ U.K. The mitochondrial processing peptidase. International Journal of Biochemistry \& Cell Biology, v.29, n.8-9, p.10431045, 1997. 
BRINCK, S.; FLÜGGE, U-I.; CHAUMONT, F.; BOUTRY, M.; EMMERMANN, M.; SCHMITZ, U.; BECKER, K.; PFANNER, N. Preproteins of chloroplast envelope inner membrane contain targeting information for receptordependent import into fungal mitochondria. The Journal of Biological Chemistry, v.269, n.23, p.16478-16485, 1994.

BRUCE, B. The role of lipids in plastidial protein transport. Plant Molecular Biology, v.38, n.1-2, p.223-246, 1998.

BRUCE, B. Chloroplast transit peptides: struture, function and evolution. TiBS, v.10, n.10, p.440-447, 2000.

CARTWRIGHT, P.; BEILHARZ, T.; HANSEN, P.; GARRETT, J.; LITHGOW, T. Mft52, an acid-bristle protein in the cytosol that delivers precursor proteins to yeast mitochondria. The Journal of Biological Chemistry, v.272, n.8, p.5320-5325, 1997.

CHABREGAS, S.M.; LUCHE, D.D.; FARIAS, L.P.; RIBEIRO, A.F.; VAN SLUYS, M-A.; MENCK, C.F.M.; SILVA-FILHO, M.C. Dual targeting properties of the $\mathrm{N}$-terminal sequence of Arabidopsis thaliana THI1 protein to mitochondria and chloroplasts. Plant Molecular Biology, v.46, n.6, p.639-650, 2001.

CHAUMONT, F.; O'RIORD, V.; BOUTRY, M. Protein transport into mitochondria is conserved between plant and yest species. The Journal of Biological Chemistry, v.265, n.28, p.16856-16862, 1990.

CHAUMONT, F.; SILVA-FILHO, M.C.; THOMAS, D.; LETERME, S.; BOUTRY, M. Truncated presequences of mitochondrial F1-ATPase $\beta$-subunit from Nicotiana plumboginifolia transport CAT and GUS proteins into mitochondria of transgenic tobacco. Plant Molecular Biology, v.24, n.4, p.631-641, 1994. 
CHEN, K.; CHEN, X.; SCHNELL, D.J. Initial binding of preproteins involving the Toc159 receptor can be bypassed during import into chloroplasts. Plant Physiology, v.122, n.3, p.813-822, 2000.

CHOI, G.H.; MAREK, E.T.; SCHARDL, L.C.; RICHEY, M.G.; CHANG, S.; SMITH, D.A. sti35, a stress-responsive gene in Fusarium spp. Journal of Bacteriology, v.172, n.8, p.4522-4528, 1990.

CHOW, K-S.; SINGH, D.P.; ROPER, J.M.; SMITH, A.G. A single precursor for Ferrochelatase-I from Arabdopsis is imported in vitro into both chloroplast and mitochondria. The Journal of Biological Chemistry, v.272, n.44, p.2756527571, 1997.

CLAROS, M.G.; VINCENS, P. Computational method to predict mitochondrially imported proteins and their targeting sequences. European Journal of. Biochemistry, v.241, n.3, p.779-786, 1997.

CORSI, A.K.; SCHEKMAN, R. Mechanism of polypeptide translocation into the endoplasmic reticulum. The Journal of Biological Chemistry, v.271, n.48, p.30299-30302, 1996.

CREISSEIN, G.; REYNOLDS, H.; XUE, Y.; MULLINEAUX, P. Simultaneous targeting of pea glutathione redutase and of a bacterial fusion protein to chloroplast and mitochondria in transgenic tabacco. The Plant Journal, v.8, n.2, p.167-175, 1995.

CUNILLERA, N.; BORONAT, A.; FERRER, A. The Arabidopsis thaliana FPS1 gene generates a novel mRNA that encodes a mitochondrial farnesyldiphosphate synthase isoform. The Journal of Biological Chemistry, v.272, n.24, p.15381-15388, 1997 
DALBEY R.E.; ROBINSON, C. Protein translocation into and acroos the bacterial plasma membrane and the plant thylakoid membrane. TIBS, v.24, n.1, p.17-22, 1999.

DANPURE, C.J. How can the products of a single gene be localized to more than one intracellular compartment? Trends in Cell Biology, v.5, n.6, p.230238, 1995.

DRESES-WERRINGLOER, U.; FISCHER, K.; WACHTER, E.; LINK, T.A.; FLÜGGE, U.-I. cDNA sequence and deduced amino acid sequence of the precursor of the 37-kDa inner envelope membrane polypeptide from spinach chloroplasts. Its transit peptide contains an amphiphilic alpha-helix as the only detectable structural element. European Journal of Biochemistry, v.195, n.2, p.361-368, 1991.

DUARTE, K.M.R. Anticorpos monoclonais aplicados à agricultura. Piracicaba: NAPMA/ESALQ-USP, 1996. 48p.

DUCHÊNE, A-M.; PEETERS, N.; DIETRICH, A.; COSSET, A.; SMALL, I.D.; WINTZ, $H$. Overlapping destinations for two dual targeting glycyl-tRNA synthetases in Arabidopisis thaliana and Phaseolus vulgaris. The Journal of Biological Chemistry, v.276, n.18, p.15275-15283, 2001.

EDWARDS, A.; JOHNSTONE, C.; THOMPSON, C. A simple and rapid method for the preparation of plant genomic DNA for PCR analysis. Nucleic Acids Research, v.19, n.6, p.1349, 1991. 
FLÜGGE, U.-I.; FISCHER, K.; GROSS, A.; SEBALD, W.; LOTTSPEICH, F.; ECKERSKORN, C. The triose phosphate-3-phosphoglycerate-phosphate translocator from spinach chloroplasts: nucleotide sequence of full-length cDNA clone and import of the in vitro synthesized precursor protein into chloroplasts. EMBO Journal, v.8, n.1, p.39-46, 1989.

FRANZÉN, L.G.; ROCHAIX, J.D.; VON HEIJNE, G. Chloroplast transit peptides from the green alga Chlamydomonas reinhardtii share features with both mitochondrial and higher plant chloroplast presequences. FEBS Letters, v.260, n.2, p.165-168, 1990.

FREARSON, E.M.; POWER, J.B.; COCKING, E.C. The isolation, culture and regeneration of Petunia leaf protoplasts. Developmental Biology, v.33, n.1, p.130-137, 1973.

FROHMAN, M.A.; DUSH, M.K.; MARTIN, G.R. Rapid production of full-length cDNAs from rare transcripts: amplification using a single gene-specific oligonucleotide primer. Proccedings of the National Academy of Sciences of the United States of America, v.85, n.23, p.8998-9002, 1988.

GABRIEL, K.; BUCHANAN, S.K.; LITHGOW, T. The alfa and the beta: protein translocation across mitochondrial and plastidial outer membranes. TIBS, v.26, n.1, p.36-40, 2001.

GIETL, C. Partitioning of Malate Desydrogenase Isoenzimes into glyoxysomes, mitochondria and chloroplast. Plant Physiology, v.100, n.2, p.557-559, 1992. 
GLASER, E.; SJÖLING, S.; TANUDJI, M.; WHELAN, J. Mitochondrial protein import in plants. Signals, sorting, targeting, processing and regulation. Plant Molecular Biology, v.38, n.1-2, p.311-338, 1998.

GLICK, B.S. Can Hsp70 proteins act as force-generating motors? Cell, v.80, n.1, p.11-14, 1995.

HACHIYA N.; ALAM R.; SAKASEGAWA Y.; SAKAGUCHI M.; MIHARA K.; OMURA T. A mitochondrial import factor purified from rat liver cytosol is an ATP-dependent conformational modulator for precursor proteins. EMBO Journal, v.12, n.4, p.1579-1586, 1993.

HEDTKE, B.; MEIXNER, M.; GILLANDT, S.; RICHTER, E.; BÖRNER, T.; WEIHE, A. Green fluorescent protein as a marker to investigate targeting of organellar RNA polymerases of higher plants in vivo. The Plant Journal, v.17, n.5, p.557-561, 2000.

HERRMANN, J.M.; NEUPERT, W. What fuels polypeptide translocation? An energetical view on mitochondrial protein sorting. Biochimica et Biophysica Acta, v.1459, n.2-3, p.331-338, 2000.

HOEKEMA, A; HIRSCH, P.R; HOOYKAAS, P.J.J; SCHILPEROORT, R.A. A binary plant vector strategy based on separation vir- and T-region of Agrobacterium tumefaciens Ti-plasmid. Nature, v.303, n.5828, p.179-180, 1983.

HUANG, J.; HACK, E.; THORNBURG, W.; MYERS, M. A yest mitochondrial leader peptide functions in vivo as a dual targeting signal for both mitochondria and chloroplast. The Plant Cell, v.2, n.12, p.1249-1260, 1990. 
HUANG, L.J-S.; WANG, L.; MA, Y.; DURICK, K.; PERKINS, G.; DEERINCK, T.J.; ELLISMAN, M.H.; TAYLOR, S.S. $\mathrm{NH}_{2}$-terminal targeting motifs direct dual specificity A-kinase-anchoring protein 1 (D-AKAP1) to either mitochondria or endoplasmic reticulum. Journal of Cell Biology, v.145, n.5, p.951-959, 1999.

HURT, E.C.; SOTTANIFAR, N.; GOLDSCHMIDT-CLERMONT, M.; ROCHAIX, J.D.; SCHATZ, G. The cleavable pre-sequence of an imported chloroplast protein directs attached polypeptides into yest mitochondria. EMBO Journal, v.5, n.25, p.1343-1350, 1986.

JACOB-WILK, D.; GOLDSCHMIDT, E.E.; RIOV, J.; SADKA, A.; HOLLAND, D. Induction of a Citrus gene highly homologous to plant and yest thi genes involved in thiamine biosynthesis during natural and ethylene-induced fruit maturation. Plant Molecular Biology, v.35, n.5, p.661-666, 1997.

JANG, S.K.; KRAUSSLICH, H.G.; NICKLIN, M.J.; DUKE, G.M.; PALMENBERG, A.C.; WIMMER, E. A segment of the $5^{\prime}$ nontranslated region of encephalomyocarditis virus RNA directs internal entry of ribosomes during in vitro translation. Journal of Virology, v.62, n.8, p.2636-2643, 1988.

JANG, S.K.; PESTOVA, T.V.; HELLEN, C.U.; WITHERELL, G.W.; WIMMER, E. Cap-independent translation of picornavirus RNAs: structure and function of the internal ribosomal entry site. Enzyme, v.44, n.1-4, p.292-309, 1990.

JEFFERSON, R.A.; KAVANAGER, T.A.; BEVAN, M.W. Gus fusions: $\beta$ glucuronidase as a sensitive and versatile gene fusion marker in higher plants. EMBO Journal, v.6, n.13, p.3901-3907, 1987. 
JOSHI, C.P. An inspection of the domain between putative TATA box and translation start site in 79 plant genes. Nucleic Acids Research, v.15, n.16, p.6643-6653, 1987.

JOSHI, C.P.; ZHOU, H.; HUANG, X.; CHIANG, V.L. Context sequences of translation initiation in plants. Plant Molecular Biology, v.35, n.6, p.993$1001,1997$.

JULLIARD, J.H.; DOUCE, R. Biosynthesis of the thiazole moiety of thiamin (vitamin $B_{1}$ ) in higher plant chloroplasts. Proccedings of the National Academy of Sciences of the United States of America, v.88, n.6, p.20422045, 1991.

KEEGSTRA, K.; CLINE, K. Protein import and routing systems of chloroplasts. The Plant Cell, v.11, n.4, p.557-570, 1999.

KIM, Y.S.; NOSAKA, K.; DOWNS, D.M.; KWAK, J.M.; PARK, D.; CHUNG, I.K.; NAM, H.G. A Brassica cDNA clone encoding a bifunctional hydroxymethylpyrimidine kinase/thiamin-phosphate pyrophosphorylase involved in thiamin biosynthesis. Plant Molecular Biology, v.37, n.6, p.955966, 1998.

KNIGHT, J.S.; GRAY, J.C. Expression of genes encoding the tobacco chloroplast phosphate translocator is not light-regulated and is repressed by sucrose. Molecular and General Genetics, v.242, n.5, p.586-594, 1994.

KOEHLER, C.M.; MERCHANT, S.; SCHATZ, G. How membrane proteins travel across the mitochondrial intermembrane space. TIBS, v.24, n.11, p.428-432, 1999. 
KOEHLER, C.M. Protein translocation pathways of the mitochondria. FEBS Letters, v.476, n.1-2, p.27-31, 2000.

KOURTZ, L.; KO, K. The early stage of chloroplast protein import involves Com70. The Journal of Biological Chemistry, v.272, n.5, p.2808-2813, 1997.

KOZAK, M. Point mutations define a sequence flanking the AUG initiator codon that modulates translation by eukaryotic ribosomes. Cell, v.44, n.2, p.283292, 1986.

KOZAK, M. Structural features in eukaryotic mRNAs that modulate the initiation of translation. The Journal of Biological Chemistry, v.266, n.30, p.1986719870, 1991a.

KOZAK, M. An analysis of vertebrate mRNA sequences: intimations of translational control. Journal of Cell Biology, v.115, n.4, p.887-903, $1991 \mathrm{~b}$.

KOZAK, M. Adherence to the first-AUG rule when a second AUG codon follows closely upon the first. Proccedings of the National Academy of Sciences of the United States of America, v.92, n.7, p.2662-2666, 1995.

KOZAK, M. Initiation of translation in prokaryotes and eukaryotes. Gene, v.234, n.2, p.187-208, 1999.

KOZAK, M. New ways of initiating translation in eukaryotes? Molecular and Cellular Biology, v.21, n.6, p.1899-1907, 2001.

LAEMMLI, U.K. Cleavage of structural proteins during the assembly of the head of bacteriophage $T_{4}$. Nature, v.227, n.259, p.680-685, 1970. 
LAND, T.; ROUAULT, T.A. Targeting of a human iron-sulfur cluster assembly enzyme, nifs, to different subcellular compartments is regulated through alternative AUG utilization. Molecular Cell, v.2, n.6, p.807-815, 1998.

LEE, J.H.; SCHÖFFL, F. GUS activity staining: a powerful tool in plant molecular biology. In: GELVIN, S.B.; SCHILPEROORT, R.A. (Ed.) Plant Molecular Biology Manual. London: Kluwer Academic Publishers, 1997. Section C5, p.1-10.

LERMONTOVA, I.; KRUSE, E.; MOCK, H.P.; GRIMM, B. Cloning and characterization of a plastidial and a mitochondrial isoform of tobacco protoporphyrinogen IX oxidase. Proccedings of the National Academy of Sciences of the United States of America, v.94, n.16, p.8895-8900, 1997.

LI, H.M.; CHEN, L.J. A novel chloroplastic outer membrane-targeting signal that functions at both termini of passenger polypeptides. The Journal of Biological Chemistry, v.272, n.16, p.10968-10974, 1997.

LITHGOW, T. Targeting of proteins to mitochondria. FEBS Letters, v.476, n.12, p.22-26, 2000.

LIU, Y.; GARCEU, N.Y.; LOROS, J.J.; DUNLAP, J.C. Thermally regulated translational control of $F R Q$ mediates aspects temperature response in the neurospora circadian clock. Cell, v.89, n.3, p.477-486, 1997.

LOWRY, O.H.; ROSEBROUGH, N.J.; FARR, A.L.; RANDALL, R.J. Protein measurement with the folin phenol reagent. The Journal of Biological Chemistry, v.193, n.1, p.267-275, 1951. 
LUKASZEWICZ, M.; FEUERMANN, M.; JEROUVILLE, B.; STAS, A.; BOUTRY, M. In vivo evaluation of the context sequence of the translation initiation codon in plants. Plant Science, v.14, n.1, p.412-423, 2000.

LÜTCKE, H.Á.; CHOW, K.C; MICKEL, F.S; MOSS, K.A; KERN, H.F; SCHEELE, G.A. Selection of AUG initiation codons differs in plants and animals. EMBO Journal, v.6, n.1, p.43-48, 1987.

MACHADO, C.R.; COSTA DE OLIVEIRA, R.L.; BOITEUX, S.; PRAEKELT, U.M.; MEACOCK, P.A.; MENCK, C.F.M. THI1, a thiamine biosynthetic gene in Arabdopsis thaliana, complements bacterial dafects in DNA repair. Plant Molecular Biology, v.31, n.3, p.585-593, 1996.

MACHADO, C.R.; PRAEKELT, U.M.; COSTA DE OLIVEIRA, R.L.; BARBOSA, A.C.C.; BYRNE, K.L.; MEACOCK, P.A.; MENCK, C.F.M. Dual role for the yeast thi4 gene in thiamine biosynthesis and DNA damage tolerance. Journal of Molecular Biology, v.273, n.1, p.114-121, 1997.

MAHADEVAN, L.; MATSUDAIRA, P. Motility powered by supramolecular springs and ratchets. Science, v.288, n.5463, p.95-100, 2000.

MAY, T.; SOLL, J. 14-3-3 proteins form a guidance complex with chloroplast precursor proteins in plants. The Plant Cell, v.12, n.1, p.53-63, 2000.

MENAND, B.; MARÉCHAL-DROUARD, L.; SAKAMOTO, W.; DIETRICH, A.; WINTZ, $H$. A single gene of chloroplast origin codes for mitochondrial and chloroplastic methionyl-tRNA synthetase in Arabidopdsis thaliana. Proccedings of the National Academy of Sciences of the United States of America, v.95, n.18, p.11014-11019, 1998. 
MIRANDA-RIOS, J.; NAVARRO, M.; SOBERON, M. A conserved RNA structure (thi box) is involved in regulation of thiamin biosynthetic gene expression in bacteria. Proccedings of the National Academy of Sciences of the United States of America, v.98, n.17, p.9736-9741, 2001.

MIREAU, H.; LANCELIN, D.; SMALL, I.D. The same Arabidopsis gene encodes both cytosolic and mitochondrial alanyl-tRNA synthetases. The Plant Cell, v.8, n.6, p.1027-1039, 1996.

MURAKAMI, K.; TANASE, S.; MORINO, Y.; MORI, M. Presequence binding factor-dependent and -independent import of proteins into mitochondria. The Journal of Biological Chemistry, v.267, n.19, p.13119-22, 1992.

MURASHIGE, T.; SKOOG, F. A revised medium for rapid growth and bioassays with tobacco tissue cultures. Plant Physiology, v.15, n.2, p.473-497, 1962.

NEUPERT, W. Protein import into mitochondria. Annual Review of Biochemistry, v.66, p.863-917, 1997.

PEETERS, N.M.; CHAPRON, A.; GIRITCH, A.; GRANDJEAN, O.; LANCELIN, D.; LHOMME T.; VIVREL, A.; SMALL, I. Duplication and quadruplication of Arabidopsis thaliana cystenil- and asparaginyl-tRNA synthetase genes of organellar origin. Journal of Molecular Evolution, v.50, n.5, p.413-423, 2000.

PELLETIER, J.; SONENBERG, N. Internal initiation of translation of eukaryotic mRNA directed by a sequence derived from poliovirus RNA. Nature, v.334, n.6180, p.320-325, 1988. 
PETERSON, M.; PERRY, R.P. Regulated production of $\mu_{\mathrm{m}}$ and $\mu_{\mathrm{s}} \mathrm{mRNA}$ requires linkage of the poly $(A)$ addition sites and is dependent on length of the $\mu_{\mathrm{m}}-\mu_{\mathrm{s}}$ intron. Proccedings of the National Academy of Sciences of the United States of America, v.83, n.23, p.8883-8887, 1986.

PFALLER, R.; PFANNER, N.; NEUPERT, W. Mitochondrial protein import. By pass of proteinaceous surface receptors can occur with low specificity and efficiency. The Journal of Biological Chemistry, v.264, n.1, p.34-39, 1989.

PFISTERER, J.; LACHMANN, P.; KLOPPSTECH, K. Transport of proteins into chloroplasts. Binding of nuclear-coded chloroplast proteins to the chloroplast envelope. European Journal of Biochemistry, v.126, n.1, p.143-148, 1982.

PILON, M.; KRUIJFF, B. de; WEISBEEK, P. New insights into the import mechanism of ferredoxin precursor into chloroplast. Journal of Biological Chemistry, v.267, n.4, p.2548-2556, 1992.

PRAEKELT, U.; BYRNE, K.L.; MEACOCK, P.A. Regulation of THI4 (MOL1), a thiamine-biosynthetic gene of Saccharomyces cerevisiae. Yeast, v.10, n.4, p.481-490, 1994.

RIBEIRO, A.; PRAEKELT, U.; AKKERMANS, A.D.L.; MEACOCK, P.A.; KAMMEN, A. V.; BISSELING, T.; PAWLOWSKI, K. Identification of agthi1, whose product is involved in biosynthesis of the thiamine precursor thiazole, in actinorhizal nodules of Alnus glutinosa. The Plant Journal, v.10, n.2, p.361-368, 1996. 
RICHTER, S.; LAMPPA, G.K. Stromal processing peptidases binds transit peptides and initiates their ATP-dependent turnover in chloroplast. The Journal of Cell Biology, v.147, n.1, p.33-43, 1999.

ROBERTS, C.S.; RAJAGOPAL, S.; SMITH, L.A.; NGUYEN, T.A.; YANG, W.; NUGROHO, S.; RAVI, K.S.; CAO, M-L.; VIJAYACHANDRA, K.; PATELLI, V.; HARCOURT, R.L.; DRANSFIELD, L.; DESAMERO, N.; SLAMET, I.; KEESE, P.; KILIAN, A.; JEFFERSON, R.A. A comprehensive set of modular vectors for advanced manipulations and efficient transformation of plants by both Agrobacterium and direct DNA uptake methods. pCAMBIA Vector release manual version 3.05, 1997. 6p.

ROBINSON, C.; HYNDS, P.J.; ROBINSON, D.; MANT, A. Multiple pathways for the targeting of thylakoid proteins in chloroplasts. Plant Molecular Biology,. v.38, n.1-2, p.209-21, 1998.

RYAN, M.T.; WAGNER, R.; PFANNER, N. The transport machinery for the import of preproteins across the outer mitochondrial membrane. The International Journal of Biochemistry \& Cell Biology, v.32, n.1, p.13-21, 2000.

SACHS, A.B. Cell cycle-dependent translation initiation: IRES elements prevail. Cell, v.101, n.3, p.243-245, 2000.

SAMBROOK, J.; FRITSCH, E.F.; MANIATIS, T. Molecular cloning: A Laboratory Manual. New York: Cold Spring Harbor Laboratory, 1989.

SCHMITZ, U.;LONSDALE, D.M. A yeast mitochondrial presequence functions as a signal for targeting to plant mitochondria in vivo. The Plant Cell, v.1, n.8, p.783-791, 1989. 
SCOTT, S.V.; THEG, S.M. A new chloroplast protein import intermediate revels distinct translocation machineries in the two envelope membranes: energetics and mechanistic implications. The Journal of Cell Biology, v.132, n.1-2, p.63-75, 1996.

SHARP, P.A.; BERK, A.J.; BERGET, S.M. Transcription maps of adenovirus. Methods in Enzymology, v.65, n.1, p.750-768, 1980.

SILVA-FILHO, M.C.; CHAUMONT, F.; LETERME, S.; BOUTRY, M. Mitochondria and chloroplast targeting sequences in tandem modify protein import specifity in plant organelles. Plant Molecular Biology, v.30, n.4, p.769-780, 1996.

SILVA-FILHO, M.C.; WIEËRS, M.C.; FLÜGGE, U.I.; CHAUMONT, F.; BOUTRY, M. Different in vitro and in vivo targeting properties of the transit peptide of a chloroplast envelope inner membrane protein. The Journal of Biological Chemistry, v.272, n.24, p.15264-15269, 1997.

SILVA-FILHO, M.C. Translocation of a reporter protein into mitochondria is mediated by a chloroplast transit peptide and follows a normal import route. Journal of Plant Physiology, v.154, p.51-54, 1999.

SIMON, S.M.; PESKIN, C.S.; OSTER, G.F. What drives the translocation of proteins? Proccedings of the National Academy of Sciences of the United States of America, v.89, n.9, p.3770-3774, 1992.

SMALL, I; WINTZ, H; AKASHI, K; MIREAU, H. Two birds with one stone: genes that encode products targeted to two or more compartments. Plant Molecular Biology, v.38, n.1-2, p.265-277, 1998. 
SOLL, J.; TIEN, R. Protein translocation into and across the chloroplast envelope membranes. Plant Molecular Biology, v.38, n.1-2, p.191-207, 1998.

SUBRAMANI, S. (1996) Protein translocation into peroxisomes. The Journal of Biological Chemistry, v.271, n.51, p.32483-32486, 1996.

TOWBIN, H.; STAEHELIN, T.; GORDON, J. Eletrophoretic transfer of proteins from polyacrylamide gels to nitrocellulose sheets: Procedure and some applications. Proccedings of the National Academy of Sciences of the United States of America, v.76, n.9, p.4350-4354, 1979.

TRANEL, P.J.; KEEGSTRA, K. A novel, bipartite transit peptide targets OEP75 to the outer membrane of the chloroplastic envelope. The Plant Cell, v.8, n.11, p.2093-2104, 1996.

VON HEIJNE, G.; STEPPUHN, J.; HERRMANN, R.G. Domain struture of mitochondrial and chloroplast targeting peptides. European Journal of Biochemistry, v.180, n.3, p.535-545, 1989.

WACHTER, C.; SCHATZ, G.; GLICK ,B.S. Protein import into mitochondria: the requirement for external ATP is precursor-specific whereasintramitochondrial ATP is universally needed for translocation into the matrix. Molecular and Biology Cell, v.5, n.4, p.465-474, 1994.

WAEGEMANN, K.; SOLL, J. Phosphorylation of the transit sequence of chloroplast precursor proteins. The Journal of Biological Chemistry, v.271, n.11, p.6545-6554, 1996. 
WATANABE, N.; CHE, F-S.; IWANO, M.; TAKAYAMA, S.; YOSHIDA, S.; ISOGAI, A. Dual targeting of spinach protoporphyrinogen oxidase II to mitochondria and chloroplasts by alternative use of two in-frame initiation codons. The Journal of Biological Chemistry, v.276, n.23, p.20474-20481, 2001.

WILLEY, D.L.; FISCHER, K.; WACHTER, E.; LINK, T.A.; FLÜGGE, U.-I. Molecular cloning and structural analysis of the phosphate translocator from pea chloroplasts and its comparison to the spinach phosphate translocator. Planta, v.183, n.3, p.451-461, 1991.

WIMMER, B.; LOTTSPEICH, F.; KLEI, I.V.D.; VEEHUIS, M.; GIETL, C. The glyoxysomal and plastid molecular chaperones (70-kDa heat shock protein) of watermelon cotyledons are encoded by a single gene. Proccedings of the National Academy of Sciences of the United States of America, v.94, n.25, p.13624-13629, 1997.

YANISCH-PERRON, C.; VIEIRA, J.; MESSING; J. Improved M13 phage cloning vectors and host strains: nucleotide sequences of the M13mp18 and pUC19. Gene, v.33, n.1, p.103-109, 1985. 
APÊNDICE

(ARTIGO PUBLICADO) 

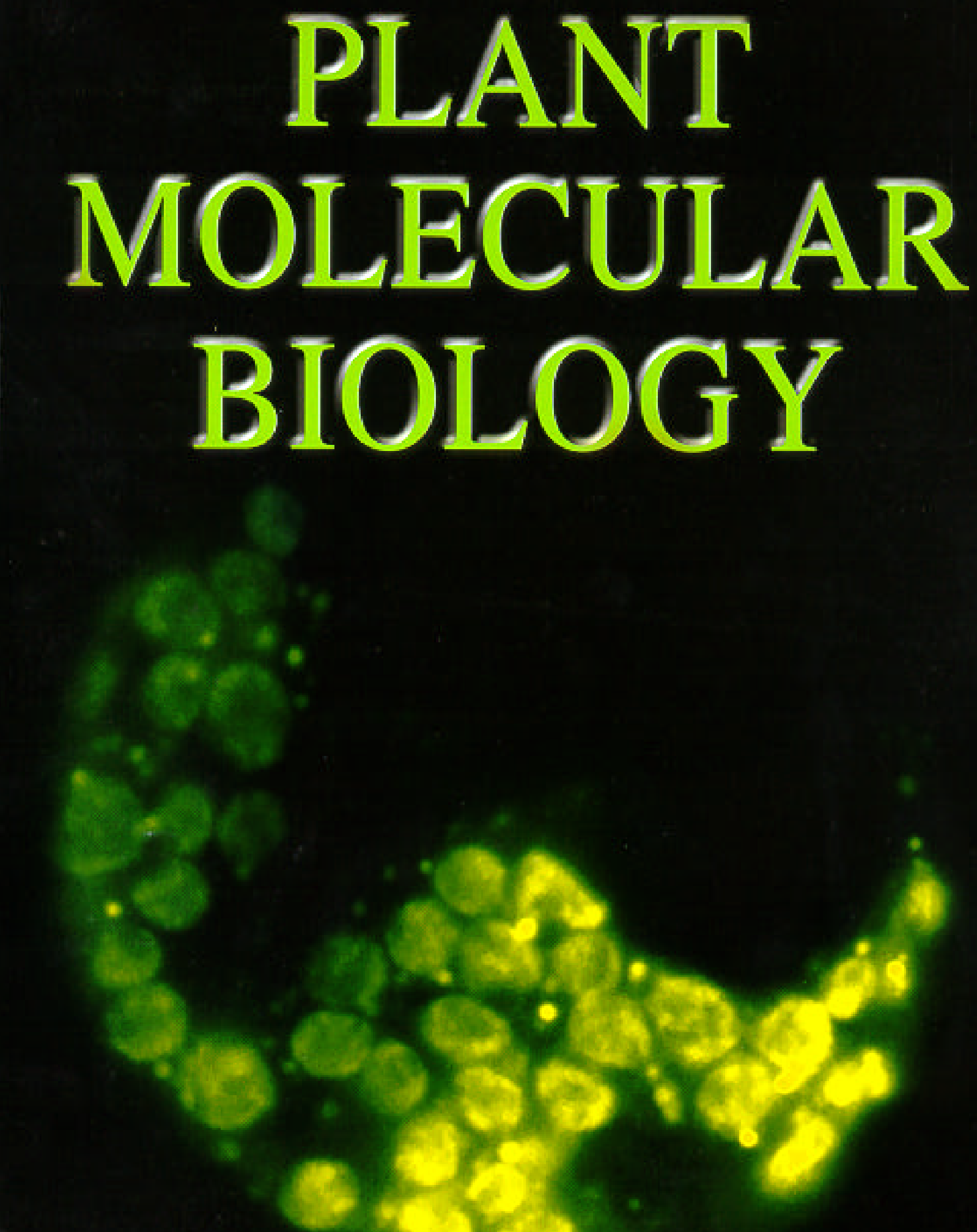

$\triangle$ International Society for ISPMB Plant Molecular Biology

Kluwer Academic Publishers
Dual Targeting of THI1 N-terminal signal sequence 


\title{
Dual targeting properties of the N-terminal signal sequence of Arabidopsis thaliana THI1 protein to mitochondria and chloroplasts
}

\author{
Sabrina M. Chabregas'. Douglas D. Luche ${ }^{2}$, Leonardo P. Farias ${ }^{3}$, Alberto F. Ribeiro ${ }^{4}$, Marie- \\ Anne van Sluys ${ }^{3}$, Carlos F. M. Menck ${ }^{2}$ and Marcio C. Silva-Filho ${ }^{1 *}$ \\ 'Departamento de Genética, Escola Sizperior de Agricultuma 'Luiz de Queirzz', Bhiversidade de Säo Paulo, Caira \\ Possal 83, $33400-970$ Piracicala, SP, Brazb; ${ }^{2}$ Departaneno de Bicobliologia, Institato de Ciéncias Bionedicus

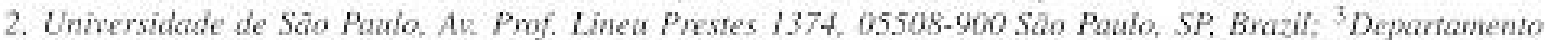

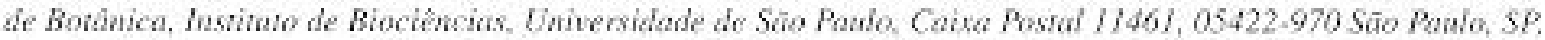 \\ Brazil: ${ }^{4}$ Departanento de Biologia, Instituto de Biociencias, Universidade de Sâo Paulo, Caixa Posal I7fol, \\ 05.22-970 Süo Putio, SP, Brazli; 'Adidress for correspondence: Deparsanento de Genética, Escola Superior de

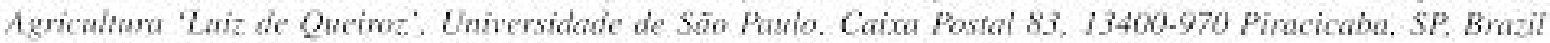

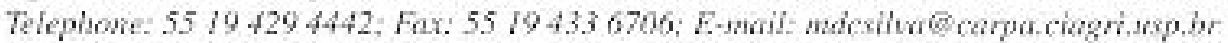

Reveivat 31 May 2000 ; axepted in revisat farm 1 Maxh zool

Key words: chloroplasts, import, mitochondria, presequence. THII, transit peptide

\begin{abstract}
finif has been recently isolated from Arzbidopsis thationa and is probably involved in both thiamine biosynthesis and as protection of organellar DNA from damage. Studies of thiamine biosynthesis in plants suggests a plastid location for the pathway, which is in agneement with the predicted THII N-terminal chloroplastic transit peptide (TP). On the other hand, thiamine is synthesized in mitochondria in yeast cells. Interestingly, A. rializan bil CDNA complements a yeast strain dismpted for the bomologous gene. Analysis of THII amino acid secjuence nevealed the presence of a putative amphiphilic $\alpha$-helix, which is typical for mitochondrial presequences, located downstream of the chloroplast transit peptide. To define the putative role of the two predicted largeting sequences in tandem, we produced two chimerio genes encompussing the chloroplastic TH1I TP and either 4 or 27 (including the putative mitochondrial presequence) N-terminal residues of the mature THII, both linked to the reporter (gasA) gene. Analysis of GUS distribution in subcellular fractions of transgenic plants revealed that in the construct retaiaing only 4 residues of mature THII, GUS was found in the chloroplastic fraction. Extension of the THI 1 transit peptide 1027 residues of the mature protein allowed import and processing of GUS into both mitochondria and chloroplasts. Direct analysis by immunogold-labeling with an anti-THII polyclonal antihody identified THI in both organelles in Ambidopsis. We also provide evidence that the precursors of both organellar isotoms are encoded by a single nuclear transcript. Thus, THI] is targeted simultaneously to mitochondria and chloroplasts by a post transcriptional mechanism.
\end{abstract}

\section{Introduction}

The majority of the mitochondria and chloroplast proteins are encoded by nuclear genes and synthesized as larger molecular weight precursors in the cyrosol. These molecules carry anino-terminal targeting sequences that are responsible for specific import of the proteins to their respective organelles (Glaser et al. 1998: Soll and Tien. [998). Analysis of mitochon- drial and chloroplast targeting signals, presequence and transit peptide, respectively, reveals some structural similarities. Both are rich in basic and hydroxylated amino acids and bave low contents of negatively charged residues (von Heijne and Nishikawa, 1989; Claros and Vincens, 1997), However, mitochondrial presequences are predicted to fold into a positively charged amphiphilic $\alpha$-helix, whereas chloro- 
plast transit peptides display a random coil structure (Schmidt et at., 1979; won Heijne er al., 1989). Therefore, protein import into mitochondria and chloroplasts is supposed to be specific, as extensively ob. served in previous work (Boutry et ah. 1987; Schnitz. and Lonsdak, 1989: Chaumont of $a$., 1990; Batata et al. 2000). On the other hand, mis-sorting of proteins has also been reported in a few cases, but in general, it does not represent a physiological event. since most cases are based on expression in heterologous hosts and unusual targeting signals (Hurt et al.. 1986: Pfaller el al., 1989: Franzén et al., 1990: Huang et al. 1990: Brinck et al., 1994; Silva-Filho, 1999).

Mitechondria and thloroplasts share some overJapping functions such as DNA replication and repair, transcription, translation. protection against oxidative stress, etc (Small $\&$ al.. 1998). As a consequence, there are some enzymes that are present in both organelles, but the general rule is that one gene encoles each isozyme. On the other hand, there are few cases showing that the product of a single gene is found in both organelles (Creissen ef al. 1995: Chow et al.. 1997: Menand $\ell t$ al. 1998: Akashi at at. 1998). This is. however, not related to mis-sorting, but a cell requirement. Apparently, this mutual targeting is due to umbivalent targeting signals (Small ct al, , 1998).

The Arwbidopsis thationa thil gene encodes an enzyme of the thiamine biosynthetic pathway. However, it was originally cloned due to its capacity to complement bacterial detects in DNA repair (Machado ef al. 1996). In addition, it has been recently shown that THIA (the Saccharonyces cerevisize thij homolog) is also involved in milochondrial DNA damage telerance (Machado et al. 1997). Thus. TH[1 may be considered as a bifunctional protein acting either in DNA repair and in thianine biosynthesis.

Thiamine pyrophosphate is an essential constituent of all living cells since it is a cofactor of major metabolic pathways such as citric acid cyele, pentose phosphate cycle, and glycolysis (Kim et al., 1998). In plant cells, it also acts as a cofactor for the plastidlocalized isozymes pyruvate dehydrogentse and transketolase. Despite the fact that the thamine biosynthetic pathway in plant cells is poorly understood, there is some evidence suggesting its occurence in chloroplasts (Belanger et al, 1995). In addition, the A. thaikana and matize THIl proteins are synthesized with typical $\mathrm{N}$-terminal chloroplastic targeting signals. In contrast, in yeast cells thiamine biosynthesis is located in mitochondria. Interestingly, the maize thil-l and Arabidopsis thil genes complement yeast striains distupted for the homologous gene (Belanger et af., 1995: Machado et al., 1997). This suggess that the chloroplast transil peptide directs transport of THII to yeast mitochondria.

In the present study, we focused on the targeting properties of the N-terminal sequence of TIIII. Analysis of the amino acid sequence revealed the presence of a putative mitochondrial presequence downstream of the chloroplas transit peptide. suggesting that THIt has two targeting signals organized in tanden. Thus, the targeting of THIl to both organelles was investigated either directly by immunological detection or cmploying two chimeric genes linking the THII putative targeting signals to $\beta$-glucuronidase (GLS), at soluble reporter protein. The data indicated that THII is in fact targeted simultancously to mitochondria and chloroplasts and also provides evidence that the chloroplastic and mitochondrial isoforms are produced by a single nuclear trancript.

\section{Results}

THII presentx nw largering signals arrarged in kenden

THI1 is encoded by a single gene in Arabidopsis sholinan (Machado et al.. 1996). It bears a chloroplast targeting signal at the $\mathrm{N}$-terminus as it has been observed in homologous genes (Machado et al., 1996: Kin et al. 1998). However, it partially complemented a yeast strain disupled with the homologous gene, an unexpected result sinee the thiamine biosynthetic pathway occurs in mitochundria in Sacchanonyces cerevisiae. A detailed analysis of the N-terminal sequence of THIl revealed the presence of a putative mitochondrial presequence downstream of the chloroplast transit peptide (Figure 1aj. Helical wheel analysis of region of 11 residues revealed the potentiality to form an amphiphilic a-helix with positively charged and hydrophobic fuces, beginning close to a potential methionine start codon (Figure lb).

\section{A single gene potentially encowes bie witochondrat and chloroplast enzynies}

The observation that THII may have two targeting signals organized in tandem led us to speculate about the bivalent targeting properties to milochonaria and chloroplasts. To verify whether THIl is divected to both organelles in vivo, we have raised 
A)

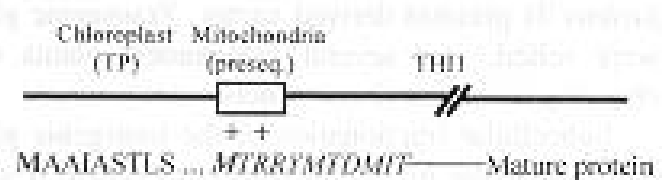

13)

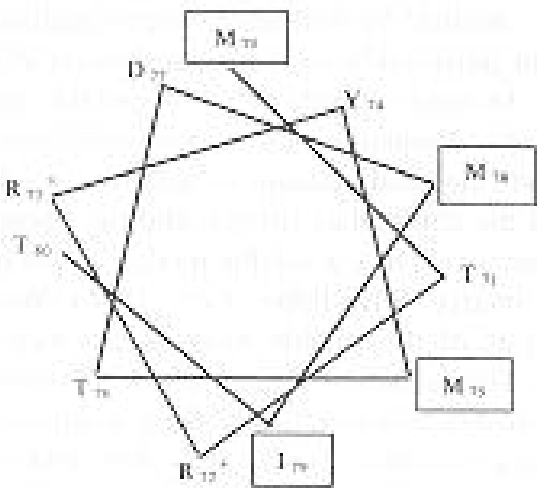

Figure 1. Schematic recresentation of lte A simiken THII $\mathrm{NH}_{2}$-terminal cxiension. $\mathrm{A}$. The consensus sequences for tramsational initistien are tenteribed with the exdons for the proposed stert methionines in boid ispe. B. Helical sbeel representation of ansine acids 70-81) in the TH[1 sequence. Hidropbobic residese are loved, and positive clarests inc indiated.

antibodies against the purified protein ufter heterologous expression in bacteria. The antibody specificity was double-checked on either Escherichia coli crude extrat of cells expressing THH (Figure 2a) or on A. thaliana homogenate from leaf cells (Figure $2 \mathrm{~b}$ ). A protein with the expected size is revealed by the antibodies in the E. coli protein preparations (Eigure 2il), confirming that the antibody is specitic for THII. However. the hands revealed by Western blot analysis in A. thaliona extracts indicated a molccular weight higher than the expected for this protein (Figure $2 b$. In addition, probing tobacco mitochondriaor chloroplast-enriched fractions with anti-THII antibody also revealed the same pattern observed in A. thationa homogenate (not shown). These results can be explained by post-translational moditication events occuring in plant cells, that would increase the protein molecular weight. This antibody prepuration was employed for in situ THI] localization. In fact, immunoGold-labeling experiments (secondary antibody conjugated to $15 \mathrm{~nm}$ gold) in Arabidopsis shoot buds demonstrated the presence of THIt in chloroplasts and mitochondria (Figure 3) with insignificant labeling in other parts of the cell. These results support
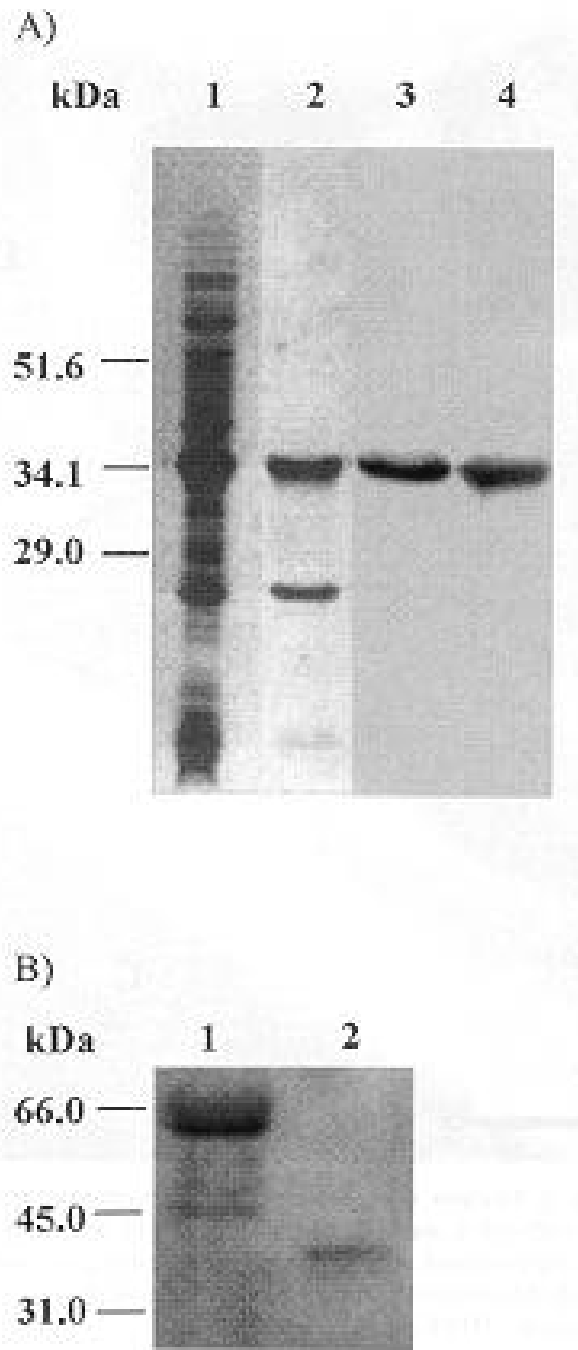

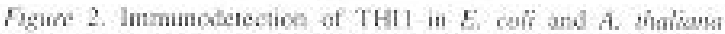
leaf cells. A. Crude extract of $f$ wafi cells $(50)$ mg) enerexpress-

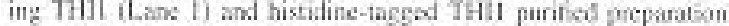
(5 $16 \mathrm{~g})$ (Laine 2) were analyzed by $15 \%$ SDS.PAGE and sraimed with Coomssie Blue (Lines 1 and 2). Lmmanodetection of crude extract

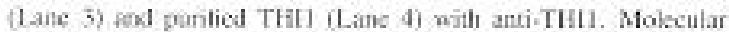
mass markers (h.Das ane shewn on the lef. B. Immunodetection of A. mabaia chide hemogense (Lase 1$)$ and purified THII (Lane 2k,

the observation that THIl is targeted simultaneously to both mitochondria and chloroplasts.

\section{Subcelledar localization of fasion proteins}

To evaluate the putative role of the amphiphilic $\alpha$ helix on mitochondrial import, we have prepared two chimeric genes. We replaced the mature THII by the GUS reporter protein since it had been previously 


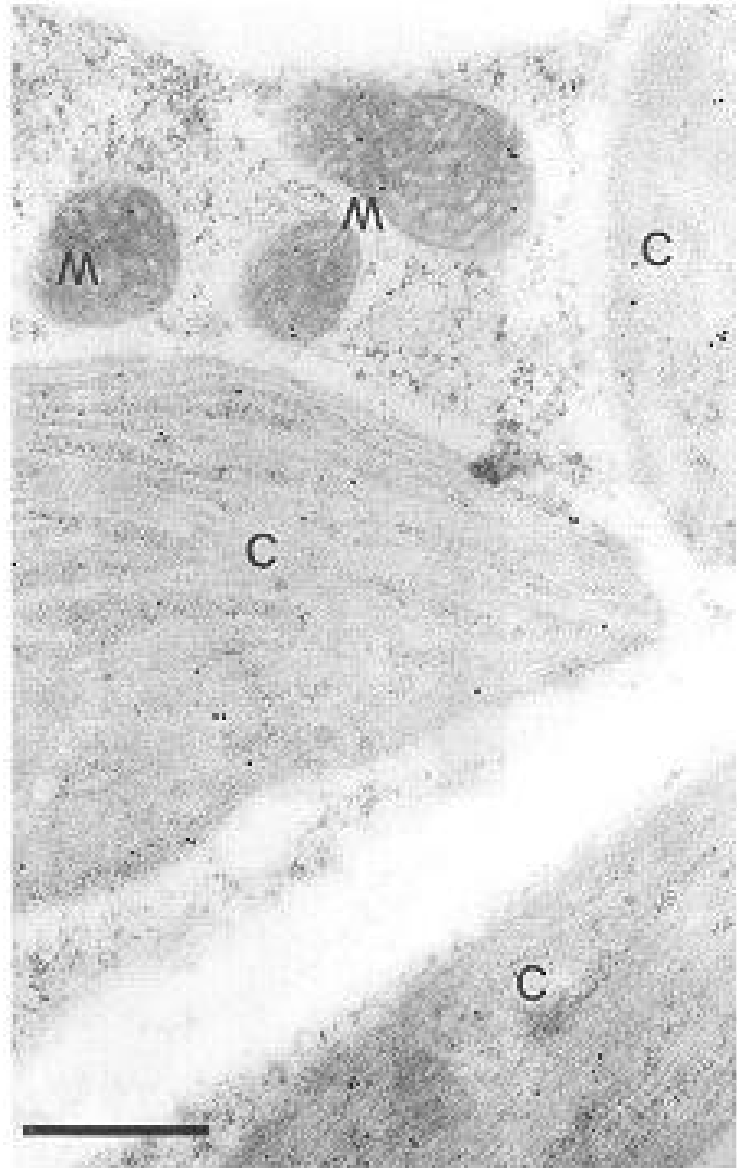

figure 3. Electron micrographs of an aldehyde-fixed cell from cos-usonit-eld $A$. shaliasta plantlet trested with an anti-tui ant body and visalixed with $15 \mathrm{~nm}$ gold cenjagzed gost anti-mouse antibody. Dees indicale $15 \mathrm{~mm}$ gokl particles in shloroplasts $(\mathrm{C})$ and mitochoondrix (M). Cahoralon bar $=0.5 \mathrm{~mm}$.

shown that according to the targeting signal, GUS is specifically targeted to either mituchondria or chluroplasts (Silva-Filho er al., 1996). The prepared constructs (Figure 4) were as follows. First, TH14-GUS, retained 4 residues of the mature THIl to still allow processing of the transit peptide which might bave required surrounding residues. Second, THI27-GUS. presented 27 residues of the mature THI, including the putative mitochondrial presequence. Since in vitro import experiments are not a good system to study specificity of protein import (Silva-Filho et al., 1997). we equipped the THI4-GUS and THI27-GUS with the strong constitutive $35 \mathrm{~S}$ transcription promoter of cauliflower mosaic virus and the $3^{\prime}$-noncoding region of a pea Rubisco small subunit gene. The chimeric genes were introduced into tobacco. using an $A$. nome- faciens Ti plasmid-derived vector. Transgenic plants were selfed, and several independent plants were characterized for both constructs.

Subcellular fractionation of the transgenic plants was performed by centrifugation to obtain a crude cylosolic supermatant and a crude organellar pel. let. Chloroplast- and mitochondria-enriched fractions were also obtained by differential centrifugation and subsequent purification of the organelles on Percoll gradients. In order to evaluate the organellar enrichment and cross-contamination, we immunodetected in all fractions the small subunit of Rubisco, a soluble marker of the chloroplast stroma, and the lipoumide dehydrogenase (LDH), a soluble marker of the mitochondrat matrix (Silva-Filho ef al., 1996). Western blet analysis of the soluble markers are shown in Figure 5a. The maximum entichment for a protein targeted to chloroplasts would be 2 -fold. assuming that chloroplastic proteins represent up to $50 \%$ of the soluble proteins of the leaf tissue. On the other hand. LDH. the mitochondrial marker, was found in higher levels in the mitochondrial enriched fractions, but absent in the chloroplastic fractions. Nevertheless, a certain amount of Rubisce was observed in the mitochondrial fraction, as reported previously (Silva-Filho et al., 1997). We must point out that targeting efficiency is difficult to evaluate precisely since part of the organellar proteins are released daring homogenization. Therefore, the use of organellar soluble markers are essential to estimate the cross-contamination.

GUS activity was performed by gel staining antalysis of THI4-GUS showed that the reporter protein was only addressed to chloroplasts, with a similar Rubisco enrichment in the chloroplast fraction (Figure 5b). The presence of a small activily in the mitochondrial fraction can be due to a contamination by chloroplast proteins, as observed with the Rubisco marker. Processing of the chimeric protein inside the chloroplasts occurred at the expected site and no GUS activity was observed with non-transformed plants. On the other hand, THI27.GUS plants showed GUS activity in both mitcchondrial- and chloroplastic-enriched fractions. Probing both organellar fractions with the antiserum against LDH or Rubisco confirmed that there was no signifricant cross-contamination. For each construct, we found that GUS activity varied from plant to plant, what probably represents the so-called position-effect. Nevertheless, the general distribution of activity in the subcellular fractions was similar for plants with the same construct. 


\section{THItGUS}

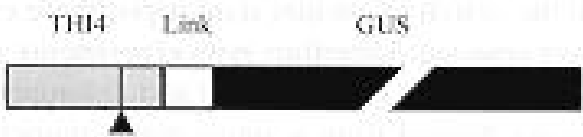

DMCCTCAMATGGCTGCCATAGCTTCT ACTCACTCTCTTCOTCAACCAAACCTCAC T L S L S S T K \& Q AGACITTTCGATTCTTCCTTCCATGGCTCA R L L F D S S F H G S GCCATCRCCGCAGCTCCTATCTCCATCGGT $\begin{array}{llllllllll}A & \mathrm{~S} & \mathrm{~S} & \mathrm{P} & \mathrm{P} & \mathrm{S} & \mathrm{S} & 1 & \mathrm{G}\end{array}$ CTCAAACCACOATCTTICTCCGTICGCGCC

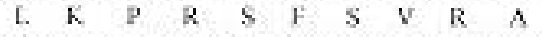
ACACCGCTGGTTACGACTTGANCGCTTIC $\mathrm{T}$
$\mathrm{T}$ ACGTTCGACCCAAGCTIGCGGGGTEOCAG $T F \quad D \quad P \quad S L \&$ \& $G Q$ TCcCTIATE.

$S$ i $\mathrm{I}$

\section{TH127-GUS}

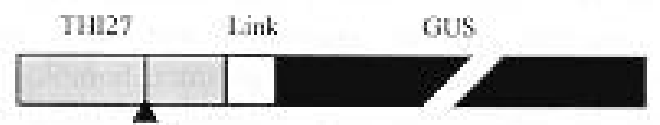

AAGECTCAAAATGGCTGCCATAGCTTCT

$$
\text { M } A \wedge \text { i } A \text { S }
$$

ACTCTCTCTCTTTCTTCANCANACTCA

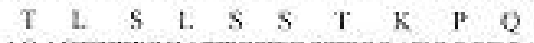
AGACTTTCCGATTCTTCCTTCCATGECTCA R L L F D $S$ S F H G S GCCATCTCCGCAGCTCCIATCTCCATCGGI

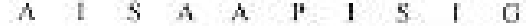
CTCAAACCACGATCTTCMCCGTTCGCQCC L. $K$ P $R \quad \& \quad F \quad \& \quad V \quad K \quad A$ ACAACCGCTOGIT ACGACTTGAACGCTTC T T A G Y D L N A ACGTTCGACCCGNTCAAGGAATCGATCGTO $\mathrm{T} F \mathrm{D} P \mathrm{P}$ K E S I V TCACGTGAGATGACGAGAMGGTACATGACG $\begin{array}{lllllllllll}S & R & E & M & T & R & R & Y & M & T\end{array}$ GATATGATCACTIATGCTGGAANOTTKEGG I) $\mathrm{M}$ I T Y A G $\bar{S}$ I R GGTGGTCAGTCCCTTATG

$$
G \quad G \quad Q \quad S \quad \& \quad M
$$

Figwe s. Chimeric THI4-GUS and TH127-GUS gene sonistrucls Below the scheme of the THI4.GLS and the THI23-GIIS consinucts ane slown with tho roxlectide and aminozid sejuences from the THII if atisit peptide. the kept mature TJIIt, as well as the linker repion tupstream of the GUS initistion coden. linker anino scid residues are in ifuikex. FimdIII restriction siles are unürlined. GUS and THIL-GUS initiation codans are in bold. The verties anow havd represenss the clestage point between the THIl teansit peptis. sod the mature peotein. Drawing is nat to scale.
A)

Rubisco

LDH

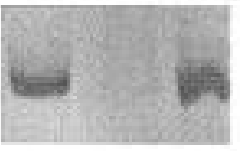

B)

$\mathrm{H} \quad \mathrm{C} \quad \mathrm{M}$

GUS

(THL)

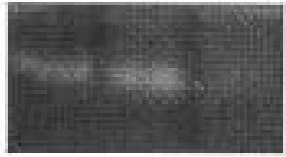

GUS

(TH27)

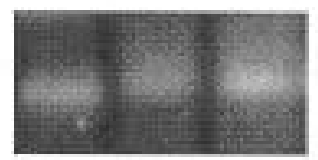

c)

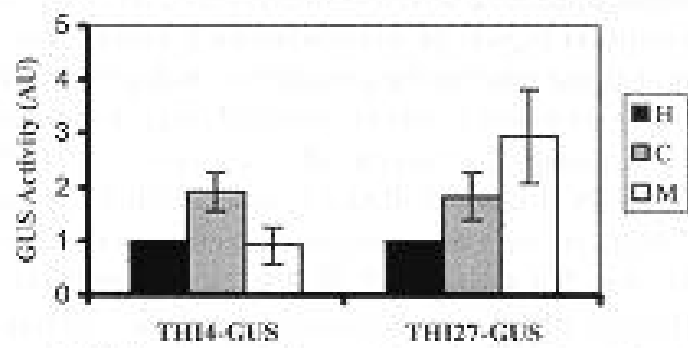

Figure 5. GLS activity and immunodetection of markers in subeeflular feactions of transestaic plints. Hejmoperization and sub. extlular fenctionatioe of TH14-GUS and TH127-GUS transpenics plants were camiad ou as desentod ubler 'Eepcrimental Proce dures'- Westem hloc analysis was carried out on 2- (Rubiseo) or 1 Tipoumide dehydrogenasey as proteins =xd GUS actriviy act staining in 50 ag peoteins of the hemagenate $(\mathrm{H})$, the chloroplasr $(\mathrm{C})$ and the mikochandria (M) enriched fractions. A. Western bloc analysis

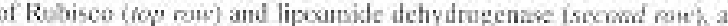
chloroplast and mitochoceltia marker. rospectively. B. GLS activisy sel staining of TH14-GUS (top row and THI27-GUS isecrond rant C. GLS specific activity in subcellider tractions selerminas by flet orimetry. The distribution of GUS activiny in chloroplast ICI amt the mitochondria (M) enriched fractions aas expoessed in atbitary units with respect wo sctivity observed in the hamogenate. Resulss are the nxean 5 SD of 3104 independent preparations. 
GUS specific activity was also determined by fluorometry in subcellular fractions of the transgenic plants. The distribution of GUS specific activity in cach fraction was expressed with respect to the activity observed in the homogenate (Figure 5cl. Analysis of fractions enriched in either chloroplasls or mitochondria makes it possible to determine the extent the reporter protein is addressed to each organelle. Encyme aclivity analysis of GUS in a THI4-GUS plants shows that the reporter protein was addressed to chloroplasts since GUS and Rubisco enrichment in the chloroplast fraction was similar (Figure $5 \mathrm{c}$ ). There was no enrichment in the mitochondrial fraction. On the other hand, GUS activity in THI27-GUS plants confirmed the presence of GUS associated to the thloroplast and mitochondrial fractions. We therefore conclude that in viv the THII transit peplide together with 4 residues of the mature THII is not sufticient to address GUS into mitochondria.

THII is encoded by a single major nucicur transcript

A detailed analysis of the S'-ftanking region of this CDNA (Figure 1a) revealed the presence of an inframe AUG located 217 bp downstream from the ATG start codon used in the translation of the chloroplastic isoform. Thus, transtation initiation from the 2nd AUG could generate a different isoform with an $\mathrm{N}$-terminal extension rypical of mitochondrial preseyuences. To investigate whether the presence of multiple transcriptional start sites would be involved on proper organellar targeting, we determined the 5 'end of thil mRNA by the PCR-based 5 -RACE ${ }^{3}$ system (Frohman et at. 1988). and by a S1-nuclease-protection analysis (Figure 6). A total of 63 5 -RACE cloned products for the wif mRNA were analyzed by gel electrophoresis. From these, 58 fragments support transeription initiation sile at position -39 , in relation to the first ATG (as indicated in Figure 6aj as ten randomly chosen clones were sequenced and all of them fall between positions -32 and -39 . The other clones each revealed a different transcription stan site as follows $+32,+74,+113$. +146 and +150 . These fragments do not constiture a second population of mRNA but are supposed to be a casual arrest of the in vitwo reverse transcription. For the SI-maclease experiment, the cDNA probe employed was a 402 bp fragment covering both AUG codons (Figure 6a). The probe was hybridised with tolal mRNA from A. thationa scedlings, followed by digestion with $\mathrm{S} 1$ nuclease. The protected fragment was then analyzed by sequencing-gel electrophore- sis, The results (Figure 6b) also indicate only onc protected fragment at the position -39 from the first ATG. Although the experiment was performed extensively in the search of smaller transcripts, these ones were never detected. Therefore, both experiments suggest that, in fact, the mitochondrial and chloroplastic isoforms are derived from a single major transcript. Further analysis of the nucleotide scquence surrounding the transcription site is consistent with those found for other plant genes (Joshi. 1987).

\section{Discussion}

TH[] is encoded by a single gene in Arubidopsis sholione and there are evidences that it is a bifunctional enzyme, participating in thiamine biosynthesis (Praekelt et al., 1994) and protection of mitochonśrial DNA from damage (Machado at al., 1997). Interestingly, these ativities are located in two distinct subcellulur compurtments: the chloroplasts and mitochondria. On the olher hand, in yeast cells, thiamine biosynthesis occurs in mitochondria. This fact is consistent with the observation that the Sacchawomyces cerevisiae THI4 gene product, homologous to the Arabidopsis thil gene, is targeted to mitochondria (Prackelt ef al., 1994). Previous reports have shown that Arabidopsis thil cDNA rescues both thiamine auxotrophy (Machado et at., 1996) and mtDNA damage tolerance in the thit disrupted yeast strain (Machado ef al., 1997). Thus, these data support the idea that THIl could he targeted simultaneously to both organelles Analysis of the Arabidopsis thil gene revealed the presence of two in-frame ATO colons. both of which coutd be used to initiate translation resulting in the production of proteins differing only at the $\mathrm{N}$-terminal targeting signal. Translation initiation at the first AUG would produce a precursor protein with a typical chloroplast transit peptide at the $\mathrm{N}$-terminus, This region is rich in the hydroxylated residues, serine and threonine, the hydrophobic amino acids, alanine and valine, and it has a net positive charge (Machado ol al., 1996). These features are common to chloroplast transit peptides (Keegstra et al. 1989). However, translation at the second AUG wonld release a preprotein with the ability to fold into an amphiphilic $\alpha$-helix at the amino-terminal sequence. This structure has been found in most of the mitochonsirially targeted proteins, but is absent in the transit peptides of chloroplast proteins from highter plants which are destined for the stroma or the thy- 
A)

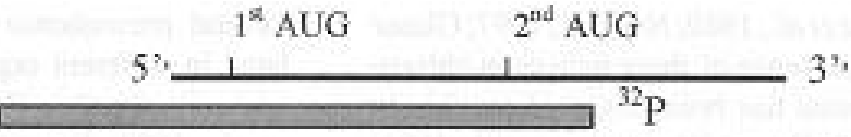
$3^{\prime}$

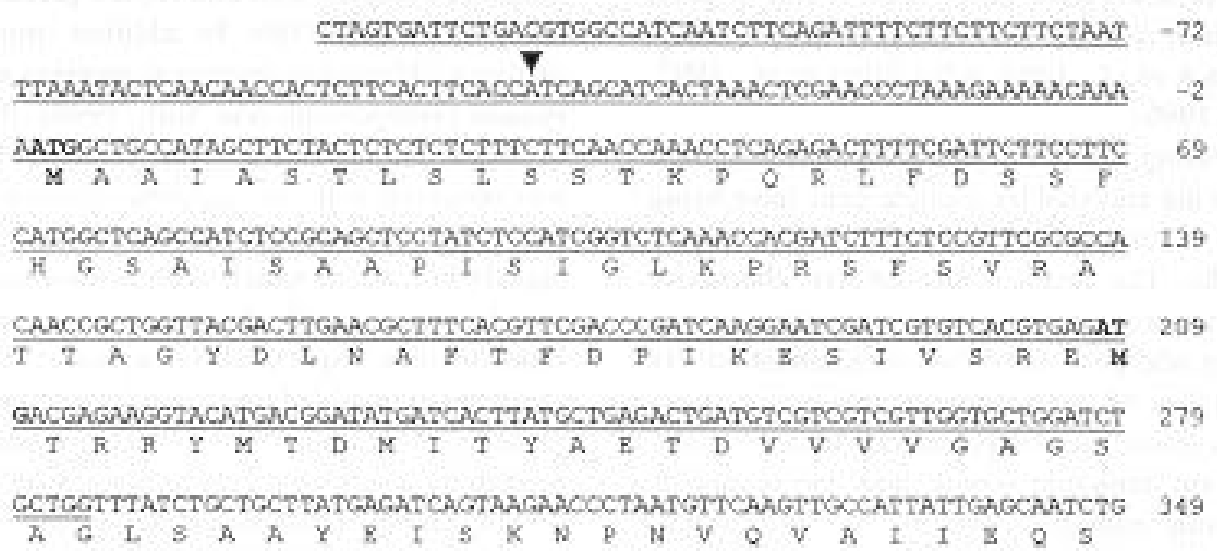

B)

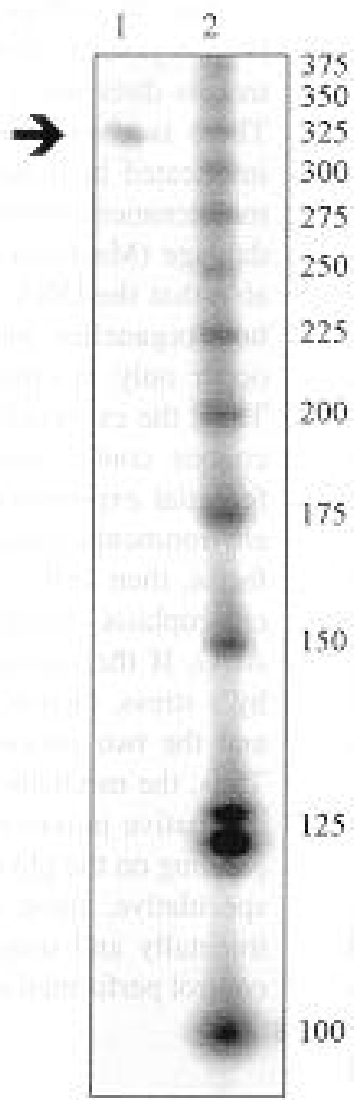

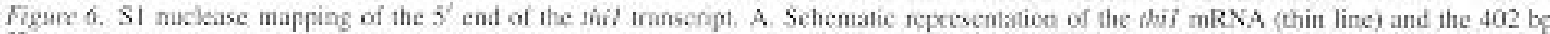

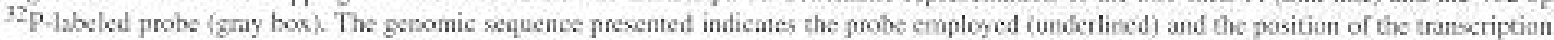

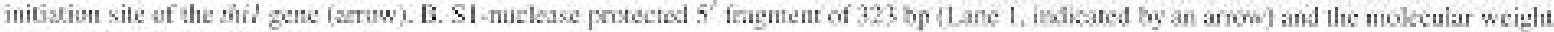
marker (Line 2, 25 bo DNa ladder). 
lakoids (von Heijne et al., 1989; Neupert, 1997; Glaser ef $a$. 1998). The presence of these helices in chloroplast targeted proteins has been observed previously Flugge ef ah. 1989: Dreses-Werringloer et al.. 1991: Willey et al. 1991; Knight and Gray, 1994), However, these proteins bave never been found in plant mitochondrit in vivo, but only in in vizo import experiments (Brinck ef al., 1994; Silva-Filino ef al. 1997: Silva-Jilho, 1999).

An increasing number of multicompartmentalized proteins that are encoded by a single gene have being observed in eukaryotic cells (Danpure, 1995; Small ct al. 1998). The mechanisms involve alternative forms of transcription initiation, Iranslation initiattion, splicing and post-translational modification. By far, most studies of multicompartmentalised proteins involve the cylosol, the compartment which is not dependent of any targeting signal, and one organelle. One interesting example concems the mitochondrial and cytosolic alanyl-tRNA synthelases which are formed depending on which of the two starting codons are used (Mireau et al., 1996). Similarly, the FPSI gene in $A$. ihaliana also determines the cytosolic or miluchondrial location of the encoded protein by an alternative use of two in-frame start codons (Cunillera. of al, 1997). This mechanism may also be related to the subxellular localization of THI 1 into mitochundria and chloroplasts. Few examples in plant cells that have shown a single gene giving rise to transcripts with different 5 ' ends could direct protein translocation to distinct organclles by the modulated use of its targeting signals iCunillera ef ol, 1997; Wimmer ct at. 1997). However, this strategy is unlikely in the case of the Arabidopsis shil gene, since the data presented strongly suggest that there is a single nucleat transcript.

The ccurrence of a duuble-targeting signal in a single protein is far less freguent. In the case of an artificial gene, that has been created by the fusion of a mitochondrial and a chloroplastic targeting sig. nal in both orientations with a passenger protein, the mos $\mathrm{N}$-terminal sequence determined the final lecalisation (Silva-Filho of al., 1996). It appears that the $\mathrm{N}$-terminus affects somehow the access of the second turgeting sequence (Danpure, 1995). This supports the observation that when two targeting signals are present, one of them out-competes the other (Small ef al, 1998). Supporting evidence against the presence of two targeting signals conferring import competence to mitochondria and chloroplasts relies on specific interations with distinct cylosolic factors.
Several presequence binding factors have been isolated in different organisms, assuring proper import into mitochondria (Murakami et al., 1992; Hachiya et ai., 1993; Cartwright et al., 1997). Recently, it was reported that cytosolic $14-3-3$ proteins form a guidance complex with chloroplast precursor proteins (May and Soll, 2000). In addition, transit peptides of major chloroplast precursor proteins are phosphorylated (Wacgemunn and Soll. 1996), bat not those of plant mitochondria. One remarkable exception was observed with the targeting of the mitochondrial P450MT2. The precursor protein carries two targeting signals in tandem which are responsible for specific translocation to both the endoplasmic reticulum and mitochondria, respectively (Bhagwat et al., 1999). The mechanism involved on the dual targeting relies on a protedytic cleavage of an N-terminal segnent of the protein by a cytosolic endoprotease which activates a cryptic mitochondrial targeting signal (Addya et al., 1997).

The physiological purpose for directing THII to both orginelles as well as the mechanisms that control its direction to one of the targets are unknown. There is considerable evidence that this protein is implicated in thiamine biosynthesis and also in the maintenance of organellar genome stability after DNA dumage (Machado es al. 1996, 1997). It is conceivable that the DNA damige tolerance is necessary for both organelles, but the thiamine synthesis seems to occur only in chloroplasts (Belanger et al., 1995). Thus, the existence of two alternative initiation AUG codons could have evolved from the need of differential expression of each function, depending on environmental conditions. If thiamine is a limiting factor, then THI would be preferentially targeted to chloroplasts, being translated mainly from the first AUG. If the organellar genetic material is damaged by at stress, then both initiation codons are employed and the two isoforms of THII would be produced. Thus, the mechanisms that control the use of the two alternative initiation codons should be complex, depending on the physiological cell condition. Although speculative, these assumptions can be tested experimentally and may reveal a new protein expression control performed at the ribosomal level in plants. 
Material and methods

\section{Gene Constraction}

Standard procedures were used for recombinant DNA work (Sambrook et al., 1989). The constructs assembling the this latgeting signals and GUS were made as follows. The thit full length CDNA was cloned into the $\mathrm{KS}(+)$ Blue Scriph (Stratagene). It carries the 5 -noncoding region. the entire transit peptide and the whole amino acid sequence of mature THIt. Two 3 '-shortened fragments were obtained by polymerase chain reaction. The first (THl4) coresponds to the entire THIl trunsit peptide followed by 4 amino acids from mature THIl; the second (TII27) wornprises the whole THII transit peptide and 27 amino acids from mature THI 1 , including the putative mitochondrial presequence. Synthetic primers provided with flanking HindIII sites were as follows. The THI4 and THI27 upstream primer was 5'CCCAAGCTTCAAAATGGCTGC. The THI4 downstream primer was S'.CCCAAGCTTGGGTCGAACG TGAAAGC. The THI27 downstream primer was 5'CCCAAGCTTCCAGCATAAGTGATC.

After PCR amplification, the fragments were digested with Histill and subcloned into the Hurdll site of the polylinker region of SK(+)BlueScript, resulting in the THI4 and TH127 plasmids, respectively. The constructs were checked by sequencing.

The GUS cncoding scquence was cloned at the HindII and EcoRl restriction sites of the plasmid SK(+) ges (Silwa-Filho er a.. 1996). To prepare the TIII4-GUS and THI27-GUS plasmids. the THI4 and TH127 fragments were obtained by HindII digestion of TH14 and THI27 plasmids. These fragments were inserted into the HindII site of the SK $(+)$ gus, previously digested with HindIII, resulting in THIA-GUS and THI27-GLS.

The development of plant vecrors were made as follows. The THI4-GUS and TH127-GUS plasnids were partially digested with HindII, followed by in EcoRI digestion, releasing the framents THI4. GUS and TH127-GUS, respectively, These fragments were inserted into the corresponding sites of Bin235ScatE9' (Silva-Fihho et al., 1996), digested previously with flindIII and EcoRI, producing the transformation vectors Bin2-35S-TH14-GUS and Bin2-35STHI27-GUS, respectively;
Antibody Prepanation

A N-terminal Histidine-tagged THII protein was expressed in Escherichia coli, and punified in onestep using immobilized metal affinity chromatography. This purified preparation of the protein was usedi to raise anti- $1 \mathrm{HII}$ polyclonal antibody in mouse.

\section{Electron Microscopy}

Buds from one-month Arabidopsis shalizana plantets (cut into $0.5 \mathrm{~mm}$ sections) were fixed in 48 paraformaldehyde with $0.3 \%$ glutaraldehyde in $0.1 \mathrm{M}$ phosphate buffer at $\mathrm{pH} 7.4$ for $2 \mathrm{~h}$ at $4{ }^{\circ} \mathrm{C}$. After rinsing with phosphate buffer, the material was dehy. drated in graded ethanol solutions at room temperature, and embedded in thard grade' L.R. White acrylic resin (Electron Microscopy Sciences, Fl. Washington, USA). Uttra-thin sections were cut on the ultramicrotome I.KB-Nova and collected on 200 mesh colloidoncoated nickel grids. The grids were then floated on drops of TBS at pH 7.2 containing $1 \%$ BSA (Sigma. USA), and plaked on NGS (Amersham. UK), diluted $1: 30$, for $30 \mathrm{~min}$. The secrions were then incubated overnight in the primary antisera diluted 1 -fold in TBS at $\mathrm{pH} 7.2$ containing is BSA at $4^{\circ} \mathrm{C}$. As a control, sections were incubated with non-immune serum using the same conditions. After rinsing $4 \times 5 \mathrm{~min}$ in TBS at pH 7.2 with $0.2 \%$ BSA, $0.05 \% \mathrm{NaN}_{3}$ and $0.1 \%$ Tween 20 , the samples were placed in TBS at pH 8.2 with $1 \%$ BSA and $0.05 \% \mathrm{NaN}_{3}$ for $30 \mathrm{~min}$ at room temperature, and incubated with goat anti-mouse IgG coupled to $15 \mathrm{~mm}$ gold particles (Amersham, UK) diluted $1: 15$ in TBS at $\mathrm{pH} 8.2$ plus I $1 \%$ BSA and $0.05 \%$ $\mathrm{NaN}_{3}$ for 1 h at room temperature. The grids were then washed $4 \times 5 \mathrm{~min}$ in TBS at pH 7.2 containing $0.2 \%$ BSA, $0.05 \% \mathrm{NaN}_{3}$ and $0.1 \%$ Tween 20 , followed by the same solution without BSA $(2 \times 5$ min). After fixation in $2.5 \%$ glutaraldehyde in $0.1 \mathrm{M}$ sodium cacodylate buffer pH 7.4 for 10 min at room temperature. the samples were finally washed in double distilled water, stained with uranyl acetute and lead citrate, and examined in a Zciss EM 900 electron microscope.

\section{Transforwation of Tobacen}

A medified freeze-thaw method for transformation of Agrobacterian tumefaciens with the plant expression vectors was used (Hofgen and Willmitzer, 1988), Leaf discs of Nicotiana tabacum cv SRI were infected, and transgenic plants were raised as described (Rogers 
cf $a\}$, 1986). All the experiments reported were cartied out on FI plants obtained after self-crossing.

\section{Sabcelluar Fractionation of Transgenic Plants and Protein Quanthation}

Subcellular fractions were obtained from $10 \mathrm{~g}$ of leaves as described previously iChaumont of at., 1994). except that homogenization was performed in $100 \mathrm{ml}$ of homogenization buffer and that 0.25 (w/v) polyvinylpyrrolidone was added to the buffer. Puritication of chloroplasts on a continuous Percoll gradient was performed as described (Bruce of al., 19941. Protein concentration was determined by the enhanced alkaline copper assay (Lowry of al., 1951\} using bovine serum albumin as a standard.

\section{Enzwie Acrivio}

GUS activity was measured either by fluorometry, using the substrate 4-methyl-Lumbelliferyl- $\beta$-D glucuronide (Jefferson et af.. 1987), or by staining gels as essentially described (Lee and Scbüfll. 1997).

\section{Western Blot Aratysis}

After sodium dodecyl sulfate-polyacrylamide gel electrophoresis, proteins were transferred to a nitrocellulose membrane and immunodetected against TH[ ] (1/500), lipoumide dehydrogenase $(1 / 2,500)$, ribulose 1,5-biphosphate carboxylase $(1 / 8,000)$, followed by alkaline phosphatase conjugated anti-rabbit (Promega) as secondary antibody.

\section{RNAse protection atzilysis}

RNA was extracted from in vino growing Arabidopsis scedlings ( 20 days old) using TRlzol teagent (Life Technologies). The 5 end of the shil mRNA was mapped by two methods: (a) by the $5^{\prime}$ RACE ${ }^{11}$ system (Life Technologies). The firs strand was synthesized from total RNA using a synthetic oligonncleotide 5' CCAGCAGATCCAGCACC 3 ' complementary to the coding sequence between positions +274 to +284 and reverse transcriptase. After first strand eDNA synthesis, the original mRNA template was removed by RNAse treatment. A homopolymeric tail was then added to the $3^{\prime}$ of the CDNA using TUT and ${ }^{3} \mathrm{CT}$. PCR were performed using the above oligonucleotide and an anchor oligonucleotide. Following amplification, 5 'RACE products were cloned into pGEM vector (Promega). The clones were analysed by sequencing. (b) by S1 nuclease protection anulysis (Sharp et al., 1980). The above oligonucleotide was ${ }^{32} \mathrm{P}$ labeled with polynucleotide kinase. The probe was generated by annealing the oligonucleotide to denatured DNA carrying the thit promoler-cosing region, extending the primer using the DNA polymerase I (Klenow fragment) and digesting with Spel. The reaction mixture was denatured and the radionctive single strand DNA probe $(402$ nucleotides) purified on an alkaline agarose gel. $50 \mu g$ of total RNA was bybridized to the single strand DNA probe followed by digestion with S1 ruclease. The protected fragment was analysed on a denaturing $6 \%$ polyacrylamide gel.

\section{Acknowledgements}

The authors ane very grateful to Dr Mare Boutry for critical reading of the manuscript and for the antiLDH antibody. The authors thank Waldir Caldeira for texhnical assistance. We also wish to thank Keila M. R. Duarte and Dr Flavio C. A Tavares for the working facilities to raise untibodies against THII, and Di Carlos A. I abare for the anti-Rubiseo antibody. This work was supported by grants 96/09124-7 and $98111119-7$ from Fundaçio de Amparo a Pesquisa do Estado de Sāo Paulo (FAPESP. São Paulo. Brazil). S.M.C., D.D.L. and I.P.F were supported by graduate fellowships from FAPESP, M.C.S.F. C.F.M.M. M.A.V.S. and A.F.R. are staff members of their respective departments and research fellows of CNPq (Brasilia, Brazil).

\section{References}

Adoya S. Anandadhectlavarada, H.K. Biswas, G.. Bhagwat. S. Mulliek, I, and Avallsati. NG. 1597. Targeling of $\mathrm{NH}_{2}$

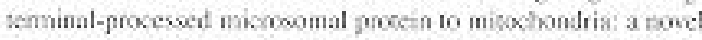
Jathway for the hoososesis of heponic mitochondrial P4501MT2 J. Cell Bint. 139: 589-599.

Akishi, K.. Gramejcan, O. and Small, 1. 1998. Potential dual tarecting of an Anabidopsis archachacterial-like histidyl-tRXA syultase so milochoondris and chlocoplasts. FEBS L.cti. 431: $39-44$

Barma, R.M. Chaguro, A, Chabregas, S.M. Goncilez, R. Lal-

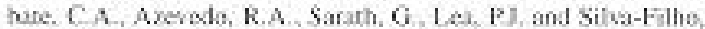
M.C 2000. Targeting of the snybean keqhemoglobin to tobocen chloroplasts: effects on asmbic metaholism in transgenic plams. Pant Sci. 155: 193-202.

Helanger. F.C., Leustek. T., Che B. and Xriz, A.L. I995. Evidenes foe the thiamise biesynthelic patiway in higher-plant plastids

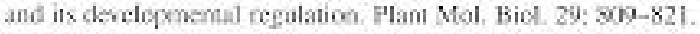

Bhagwat, S.V., Biswas, G., Anandatheenhasada. H.K., AdJys. S. Pundak, W. and Audhani, N.S5. 1999. Dual targeting propkty of 
the N-terminal signal scuperse of P4501 AL. J. Biol. Chem. 274 $24014-24022$

Beutry, M. Nagy, F, Prulsen, C. Aosagi, K. and Chua, N.-H. 1987. Targeting of hacterial chloramphenicol scelyltransferase to mitochoodria in transgenic glants. Nanere 328: 340-342.

Brinck, 5. Flugge, U.-1., Chaumont. F., Boutry, M., Emmermanto. M.. Sctumice, U., Becker, K. and Pfancer N. 1994. Preproteins of chkoroplast envelope irner membrane costain targecing informa.

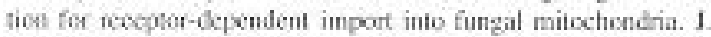
Biol. Chem. 209: 16478-16485

Bruce, B.D., Peny, S., Frodalich, J, and Kecosita. K. 1994. In vim import of proceins isus chleruplasts. In: S. B, Gelviti, snd R A Schilperowert IEds.) Plant Mol. Biol. Manual, Klawer Academic Tublishers, Section J1. Lendon, prs 1-15.

Cartwrighs, P. Bcilhars. T., Hansen. P.. Garrets, J. and L.ithers, T. 1997. Mn52, an acikd bristle peotein in the cytosal that beliners peosursor proteins to yeist milochonitria. 1. Bid. Chem. 272: $5321-5.325$.

Chaumant. F, O'Rindan, V., and Bousry, M. 1990, Proteia Ganspoet inte mitochendria is conserved berween plant and yesst precies. J. Biol. Chem. 265: L6856-16862

Glaunoul, F. Silva-Fitho, M.C. Thomas, D. lesemes S and Houlry, M. 1904. Trumcated presegoences af mitochoodriad $\mathrm{F}_{1}$ -

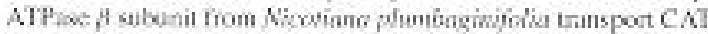
and GUS poccins inso milechondria of Irans:enic tobucoo. Plant Mol. Bial. 24: 631-641.

Chow, K.S.. Singh. D.P., Roper, I.M and Smith, A.G 19yT. A

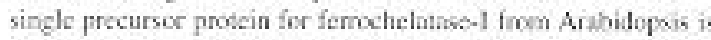
insportod in vive into beth chlocoplasts and mitoctsondria 3. Biol Cletr, 272: 27565-27571.

Claros, MG and Vincens, P. 1997. Cunputational methos! to

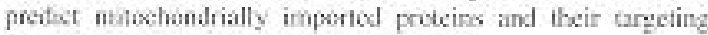
sequences. Fur, J. Biochens, 241: 779-786

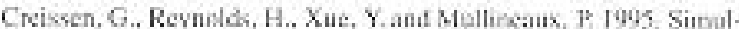
tancous taryeting of pea glatathioce redectase and of a bosertial fusion protein to chloroplasts and mitochondia in transoenic fobace. Mant 1. 8: 167-175.

Canilksa, $\mathrm{N}_{4}$ Beronal, A. and Ferrer. A. 1997. The Arathidon. sis divfinas FPSI gere generales a nowel mRNA that encodes a misochandrial famesyl-elphosperute symlase iswiorm. J Binl. Chem. 232: 15381-15288.

Dimpure. C. 1595. How can the prosluets of a single gene te loseal. ied to mure than ane intricellalar compartiment? Trends sell Bis: 5: $231-238$

Dreses-Weninglos. U., Fischer. K.. Wikther, E.. Link, T.S and

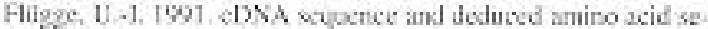
quence of the precurso of the $37-1, D_{2}$ inmer envelope mentrane polypeptite from spinach chloroplasts, Its Iratrit pepliab con tains an amphiphilic alphz-helix as the coly detaxtable stouctural element. Eur. J. Bixactem. 195: 361-368.

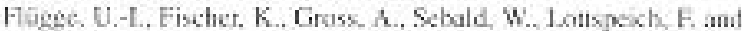
Eeherswom, C. 1989 . The triose phasphate-3 phasphoslyceratephosplese translocator from spinzch chkoroplasts: mackocide sequence of full-kegeth cENA ckone and import of the in wire synchesixed pecursor prosen into chionoplasls. EMBO J. $\$$ : 39.46.

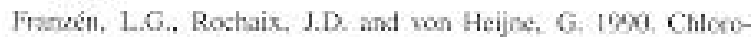
plast transit peptides frum the green alga Chawwewesus oritinuritio share features with both mitochondrial and higher plam chloroplast prescupences. FEBS Let. 260- I 65-165.

Frohman. M.A., Dush, M.K and Martin. G.K. 198s. Rapód pro ducsion of fult-iength DNAs frond rare transcripls: amplification using a single gene-specific oligenueleotxle primse. Troc. Natl. Acral. Sti. USA 85: $\$ 998-5002$.
Glaser E. Sxoling, S. Tamudii, M, and Whelan, J. 1998 Mino chondrial protein impors in plarts. Signals, sorting, targeting. processing and regulation. Mant Mol. Biol, 38-311-328.

Hachiya X, Alam R., Sakasegarna Y, Sakngochi M. Milara K and Ounara T. 1993. A mitochondrial import factor puritied from rat liver eytowol is in ATP dependent confonmational modalesor for precursor prosins, EMBO J. 12: 1579-1586.

Holgen. R. and Wiltmileer. L. 1988. Stonage competent cells for Agrotincierium Itansformatioe. Nuel. Acids Res. 16: 9877.

Ifang, J. Hack. E. Thombure, R.W. and Moxers, A. M. 1990 A yeast mitochesdrial leader pegide functions in vive as a lust lirecting signal for both chloroglast and minochandria, Plater Cell 2: $1249-1260$

Hent. E.C. Sollanifra, N. Guldxchmidt Clemonat. M., Rochaix. 3,-13, and Selıaly, $G$. 1986 The clewable presequenes of an imponed sharoplast provein dinects attachod polypeptides inte yeast matochondria, EMBO J. 5: 13.43-1350.

Jefferson. R.A., Kavanagh, T.A and Hewat, NW, 1487 . GUS fu sions: heta glucaronidase as a semsitioe and versule gene fusion marker in higher plants. EMBO I. 6: $3901-3907$.

Jushi. C.T. 1987. An inspertion of the domain herween puratow TATA box and irsenslation start site in 79 plant genes. Nucl. Acids Ko, 15. 66-43-6553

Kexgsen, K., Orsen, L.J and Theg, S.M. 1989. Cliloroplastic precursors and their mansport across the envelope menobranes. Annu. Rev. Plans Physiol. Plant Mol. Biot. 40; 471-501.

Kirr. Y.S. Nosakz. K., Doran, D.M. Kwak, J.M., Park, 1,. Chung. 1.K. and Nam, H.G. 1998. A Brassica cIXNA cione encodieg a bifunctional lnvinxyzethylpzrimidine kinasethiamin-phosphuse mereposplexylase involved in thiamin boosynthesis. Pant Mol. Bint 37: 955-96\%

Knigh, IS and Giray, J.C. 1904, Expecssion of genes entoding the

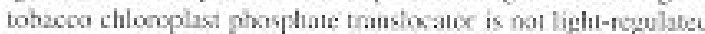
and is repossed by sucrose. Mox. Gen. Giener 242: 586-504

Lex: J.H and Schuef. E. 1993 . GUS activity staining - a powerful teet in plant molecular bislogy. In: S.B. Gelvin and R.A. Scbolperoor (Eds, Plant Mol. Biol. Manual, Kluwer Acsdemic Puhlishers, Section CS. Lendon, p. $[-10$.

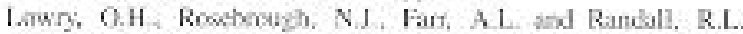
1951. Protein mensunemsent wh the folin plenol reagent 5. Biol. Chem. 193: 265-275.

Mixhado, C.R. Casta de Olivein, R..., Baiteiux S.. Prockelt U.M Meikock. P.A. and Menck. C.F.M. 1996 Wuit. a thi-

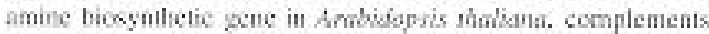
bacterial detows in DNA repair. Mant Mol. Biol. 31: 58.5-593.

Vachado, C.R., Proekelt, U.M. Cowa de Oliveira, R.L. Burbas: A.C.C. Byrne, K.I... Mearok, PA, and Menteh, C.F.M. 1997. Dual role for the yeast THI4 gene in thiamize leasyulteses ard DNa damas wlerance. J. Mul. Biol. 273: 114-121.

May, T. and Soll, J. 2XW0. 14-3-3 proseins forin a guidence complex with caloroplast pecorsor proteins in plants. Plant Cell 12:52 63 ,

Menand B., Maroctal-Drouard L. Sakamoka W.. Dictrich A. and Wienz H. 1998. A single gene of elulorcplass origin coses for mitocbondrial and chloopolastie methioxy ]-[RNA synthelase it Arabióngsis thaleana. Proc. Nati Acad. Sei. LSA 95 1101411019.

Mifeau, H. Lancelin, D. and Small, 1.D. 1956. The same Arabiong. sis gere cecodes both vylowolic and mifexthandrial alamyl-tRVA synthetases. Mant Cell 8: $2027-1039$

Murakami K, Tanzese S., Morito Y and Moci M. 1992. Presequence binding factor-dependem and -inkecendent impost of poscins inte mitochoodriz J. Biot. Chem. 26?: 13119-13122. 
Neupert, W. 1997. Protein import indo mitochomdrik. Aneas Rev Biochem. 660 : $863-917$

P'Aalkt, R. PFanter, N and Neupert. W. 1989. Mikochondrial pentein import, bypass of proteinaceous surface recepsors can occur wittlow specificity and elficierky. 1. Bxol. Chem. 264: 34-39.

Prackelt, U., Byno, K.L, and Mateock. P.A. 1994. Regulation of

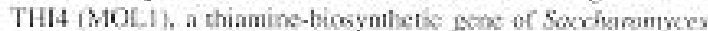
cerevisiae. Yeast 10:481-490

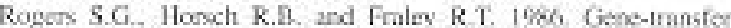
in plints-production of transormed plants using T.plasmid vectors. Methods Enxymol. 118: 627-640

Sambroak, 3. Fricstr. EF, and Maniatis. T. 1989. Molecular Clenang: A I aboranory Mantual Cold Spring Harbor Laboralory Press, New York.

Schmidt, G.W.. Devillers-Thiery, A., Desnussemx, H. Blobet, G.F and Chas. N.H. 1979. Biosyncheric pashways of rav polypentide subunits of light-harwssing chlorophyll ab poocein complex. I Ceil Bicl. 83; 615-622.

Schmilz, U, and Lonslale, D.M. 1989. A yeast mitochondrial presequence fumctions as a sugnal for larzeting is plant mitechendria in wira Pant fell 1: T85-72y

Sharp, P.র., Berk, A.J. and Barget, S.M. 1980, Transeriptom maps of idenoyinus. Metheds Enxymol. (s: 751)-768

Silvw-Fillo. M.C. 1999. Translocation of a repouter protein into milechendria is mediated by a chloroplast transit peptide and follows fit normal roule. 5. Mant Physiol. 15]: $51-54$.

Silva-Filto, M.C. Crowment. F., Leterna. S. and Boutry M. 3996. Misochondrial and chlecoplast largeting sccococes in tandem modify protein import specificity in plam coganelles. Pant Mo Biol, 30: $760-780$.

Silva-Fillo MC. Wietrs M.-C. Fiigge, U.4., Chuminnt, F and Boutry, M, 1997. Different in viro and is vivo targeting properties of the transif peptide of a chloraplast envelone inner membrane protein. J. Bint Chem 272: 15264-15260.

Small, I., Wirte. H., Akasha, K, and Mremi. H. I998. Tho birlly with sne stoos: aenes that enende prodiscls largeted to tav an moce compariments. Plant Mol. Biol. 38: 26,5-27\%.

Sel1, J and Tieo. R. 1908. Protein translocation inte and across the chloroplast exvelope membrimes. Plant Mol. Bjol. 38: 191-201?.

von Heijne, G, and Nishik:rua, K. 1989, Chluroplast iransit pep. tides. The pertect random coil'? JEBS Lell 278: 1-3.

won Ikejine, G.. Steppuhn, J. and Hermann R,Gi, 1969 Damain structure of mitochoedinal and chloroglis targeting pepsides. Eur. J. Bsocbem. IS0: 535-545.

Waegemann K. and Sall J. 1996. Phospherylation of the ransil sequence of chloroplas precursar peoteins. J. Bibl. Chem. 231. $6545-6554$,

Willey, D.1.., Fischer, K., Wacher, E., Link, T.A. and Filugge, U.1. 1991. Molscular cloning and structural stsalysis of the phos. phabe translicator from pea chicerplasts and its eomparison to the spinach pbosphate iranslocatne. Plama 183: 451-465.

Wimaner, B., Lotspeich, F.. Van Der Klei, I., Veenhuis, M. and Gictl, C. 1997. The glyuxysomal and plastid malecular chap. erones (70.k.13 heal shock protcin) of wskcrmelon cotyledons are encoded by a single gene. Prox. Nall. Acad. Sci. USA 94: $13624-13629$ 